\title{
NITROGEN AND PHOSPHORUS UPTAKE IN THE EVERGLADES CONSERVATION AREAS, FLORIDA, WITH SPECIAL REFERENCE TO THE EFFECTS OF BACKPUMPING RUNOFF
}
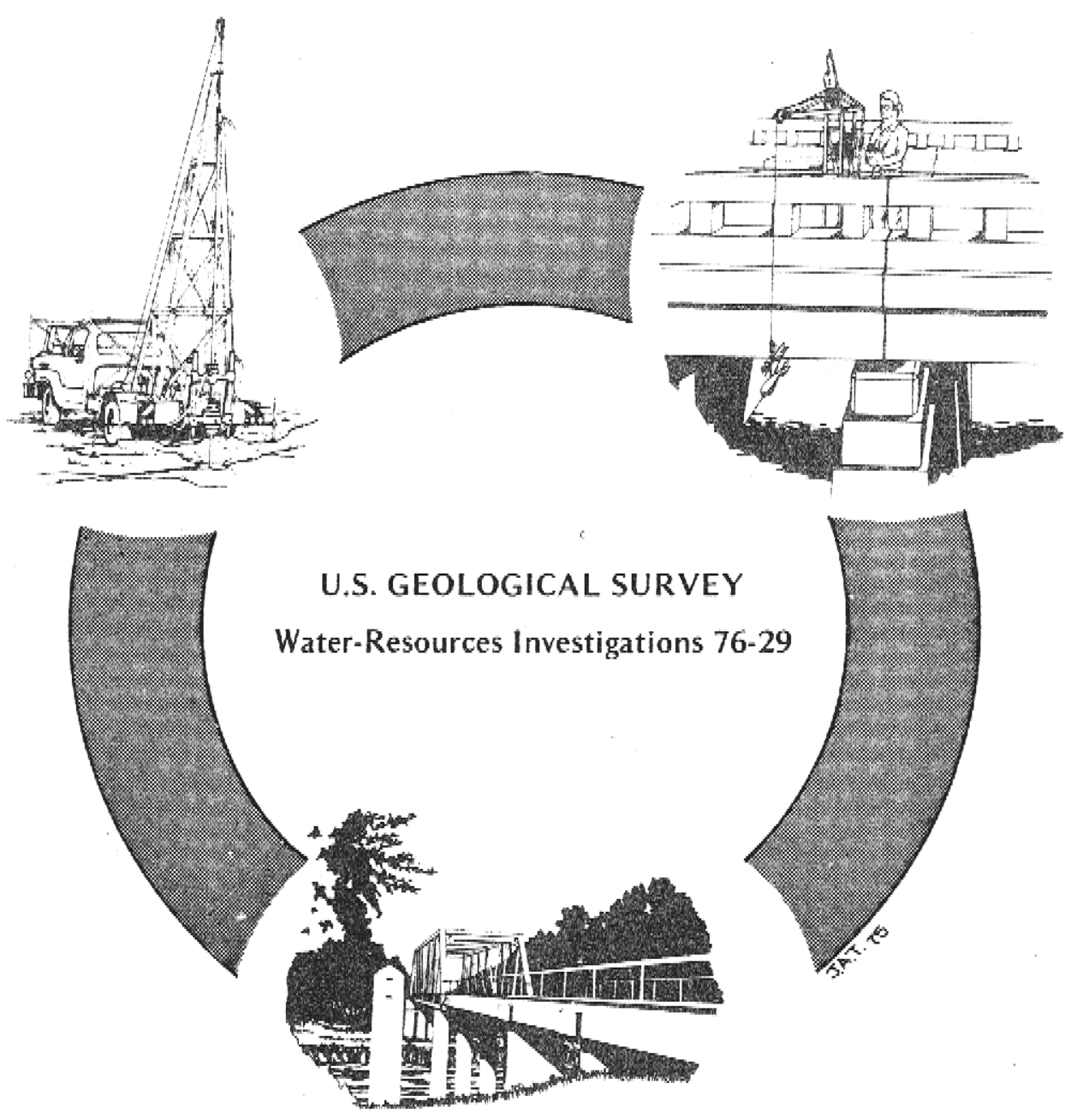

Prepared in Cooperation with the

U.S. ARMY CORPS OF ENGINEERS 


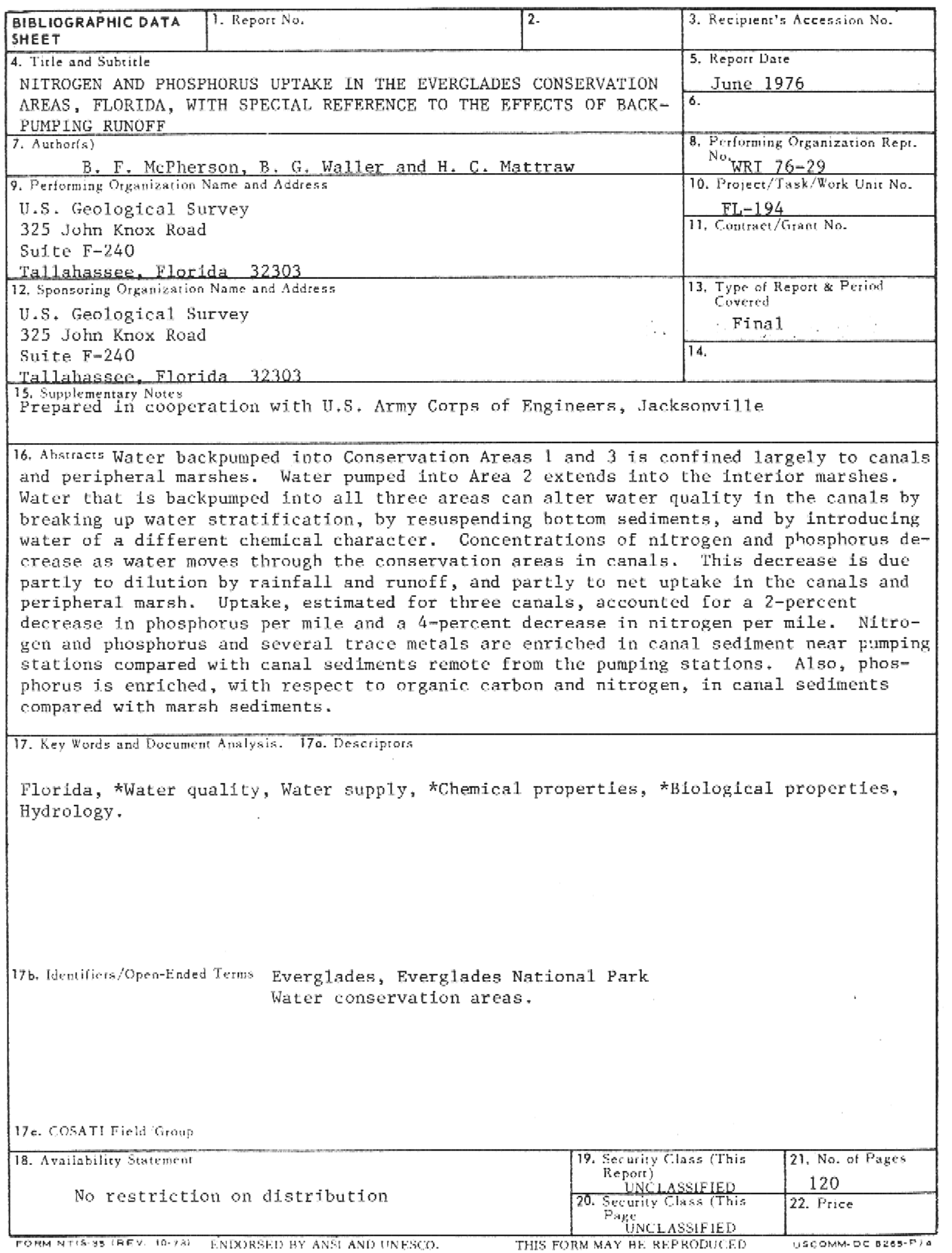


NITROGEN AND TIIOSFHORUS UPTAKE IN THE FVERGLADES

CONSERVATION AREAS, FLORIDA, WITH SPECIAL REFERENCE

TO 'HE EFFECTS OF BACKPUMPING RUNOFF.

By B. F. McPherson, B. G. Waller, and H. C. Mattraw.

U.S. GEOLOGICAL SURVEY

Water-Rosources Investigations 76-29

Prepared in cooperation with

U.S. ARMY CORPS OF ENGINEERS 
UNITED STATFS DEPARTMEN'T' OF 'IIIE INTERIOR

THOMAS 5. KLEPPE, Secrelary

GEOLOGICAL SURVEY

V. F. Mckelvey, Dirrector

For additional information write to:

U.S. Geologica1 Survey

325 John Knox Road, F-240

Tallahassee, Florida 32303 
Abstract . . . . . . . . . . . . , . . . . . . . 5

Introduction . . . . . . . . . . . . . . . . . . . . . 6

The tverglades environment . . . . . . . . . . . . 6

Backpumping plans . . . . . . . . . . . . . . . . 11

Purpose and scope . . . . . . . . . . . . . . . 13

Sampling sites ...................... . . . 13

Water chemistry characteristics . . . . . . . . . . . . . . 21

NLtrogen and phosphorus concentrations at selected sites . . 21

Nitrogen and phosphorus uptake in canals . . . . . . . . . 21 .

Nitrogen and phosphorus uptake in marshes . . . . . . . . . 23

Diel chemical changes . . . . . . . . . . . . . . . . . . 28

Jissolved oxygen . . . . . . . . . . . . . . . . . . 28

Nitrogen and phosphorus. . . . . . . . . . . . . . . 35

Chemical changes with backpumping . . . . . . . . . . . 35

Pumping station S-5A . . . . . . . . . . . . . 35

Thmping station $\mathrm{S}-9$. . . . . . . . . . . . . . . 38

Nitrogen and phosphorus loads . . . . . . . . . . . . . . 41

Bottom sediment chemical characteristics . . . . . . . . . . . . 41

Characteristics of vegetation in the Everglades margh and in

canals near pumping stations . . . . . . . . . . . . . . 54

Introdliction . . . . . . . . . . . . . . . . . . 54

Survey and sampling , , . . . . . . . . . . . . . . . 56

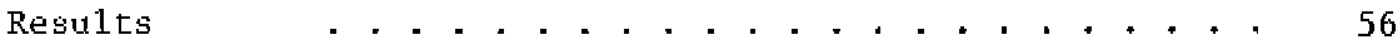

Summery and conclusions . . . . . . . . . . . . . . . . . . 59

Selected references . . . . . . . . . . . . . . . . . . . . . . . 61

Baslo Data $\Lambda$. . . . . . . . . . . . . . . . . . . . . 63

B........................... 71

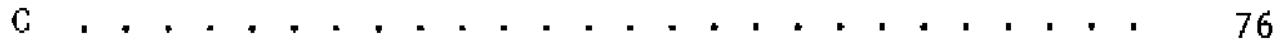

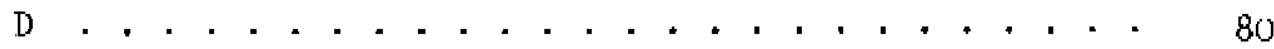

E........................... 92

l. . . . . . . . . . . . . . . . . . . 116 
Figure 1.--Map of southern Florida showing the Everglades . . . . 7

2.-Map of southern Florida showing the Everglades boundary, the conservacion areas, Everglades National Park, and arcas of agricultural development . . . . . 10

2A.--Location of existing and proposed pumping stations near the consorvation areas . . . . . . . . . . . . 12

3.--Location of nutrient transccts, canal nutrient stalions, and plant sample areas. . . . . . . . . . . . . . . 14

3A.--Locations of dicl studies . . . . . . . . . . . 15

4.--Location of sampling sltes near pumping station S-5A - . 16

5.-Location of sampling sites near puttping station S-9. . , 17

5A.--Localion of bottom sediment samples collected In canals and marshes of Conservation Area 1 in February 1974. . . 18

5B.--Location of sample areas and stations in Conservation Arcas and 1 and 2A. . . . . . . . . . . . . . . . . . . 19

6.--Specific conductance in Conservation Area 1 in september 1973 (hi.gh water) . . . . . . . . . . . . . 25

7.--Specilic conductance in Conservation Mrea 1 in January 1974 (low water) . . . . . . . . . . . . . . . . . 26

8.--Changes in specific conductance and nutrients along transects $G$ (September, 1975) and $T$ (January 1974) in. the northern part of Conservation $\Lambda$ rea $1 .$, . . . . .

9.--Changes i.n. specific conductance and nutrients along transects F' (September 1973) and P (January 1974) in the western part of Conservation Area 1 . . . . . . 30

10.--Changes in specific conductance and nutrients along transect $V$ in Conservation Area 2A . . . . . . . . . 31

11.- Changes in specific conductance and nutrients along transect J in Conservation $\Lambda$ rea $3 \mathrm{~A} ., ., ., ., ., 32$

1.2.--Diel changes in dissolved oxygen in a canal and its peripheral maxshes at the north end of Conservation

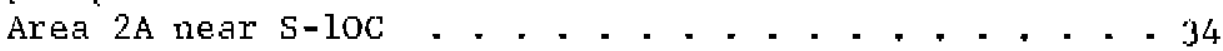

13.-biel changes in percent saturation of djssolved oxygen during four seasons aL T-2B east canal, Conservation. $\operatorname{\Lambda rea~3A...~.~.~.~.~.~.~.~.~.~.~.~.~.~.~.~.~} 36$

14.--Seasona1 changes in percent saturation of dissolved oxygen at L-28 east carla1, 1970-73 . . . . . . . . 37

15.--1)issolved oxygen concentrations in waters around $\mathrm{S}-5 \mathrm{~A}$ In Conservation Area 1, September 10-12, 1973 . . . . 39

16.--Changes in concentration of ammonia (NH3-N) at four sampling sj.tes near $\mathrm{s}-9$. . . . . . . . . . . . . . . 42

17.--Changes in concentration of ammonia (NH3-N) at six sampling sites near S-9................ . . 44

18.--Changes $i n$ the concentration of nitrate $\left(\mathrm{NO}_{3}-\mathrm{N}\right)$ at three sampling sites near $\$-9$, . . . . . . . . . 45

19.--Changes in dissolved oxygen at three sampling sites near S-9 . . . . . . . . . . . . . . . . . . . . . . 46

20.--Chariges in dissolved oxygen at three sampling sites near $\mathrm{s}-9$. . . . . . . . . . . . . . . . . .

21.--Carbon, nitrogen, and phosphorus concentrations of aquati.c plants and bottom sediments collected in the Everglades, in Janunry 1973 . . . . . . . . . . . . 5 
Table 1.--Names of sampling areas and stations

2.--Median concentrations of nitrate, nitrite, ammonia, organic nitrogen, total nitrogen and total phosphorus in miligrams per litre at pumping stations 5-5A, S-6, S-7, $\mathrm{S}-8, \mathrm{~S}-9$; at a camal L-28 remote from pumping stations; and at marsh siteg 3-28, 1-15, and 2-17. . . . . . . . . 22

2A.--Changes in nitrogen (N) and phosphorus (P) in milligrams per litre and specific conductance in micromhos per centimetre $25^{\circ} \mathrm{C}$ at pared sampling sites on canals in the conscrvation areas.................

3.--Nverage concentrations in milligrams per litre of $\mathrm{NO}_{3}$, $\mathrm{NO}_{2}, \mathrm{NH}_{3}$ (as $\mathrm{N}$ ) and $\mathrm{PO}_{4}$ (as $\mathrm{P}$ ) in the conservation areas and adjacent canals on 10-11 September, 1973 and 16-17 January 1974 , . . . . . . . . . . . . . . . . . . . . .

4.--Average concentrations of nutrients on September 10, 1973 sampling sices near 5-5A before pumping and aftor pumping . . . . . . . . . . . . . . . . . . . ..

5.--Average concentration of nutrients bofore and after purnping at $\mathrm{S}-9$ on 16-18 January 1973

6.--Average concentrations of macronutrients and selected metals and percent organic matcrial in bottom sediments at selected canals and marshes in the tverglades . . . .

7.--Average normalized concentrations of macronutrients and selected trace elements in bottom sediments , . ...

8.--Chemical analyses of bottom sediments collected in Consorvation Area 1 j.n February 1974 . . . . . . . . . .

9.--Concentrations of nilrogen and phosphorus in bottom sediment normalized to 100 grams per kilogram organic carbon, February 1974 .. . . . . . . . . . . . . . 


\title{
NI'L'ROGEN AND PHOSPHORUS UP'IAKE IN THE EVERGLADES
}

\author{
CONSERVATION AREAS, FLORIDA, WI'H SYECIAL REFERENCE
}

TO THF, EFTECTS OF BACKPUMPING RUNOTT

By

B. F. MePherson, B. G. Waller, and H. C, Mattraw

\section{ABSTRACI'}

Water currently pumped into Evergl,ades Conservation Arcas 1 and 3 is largely confined co canals and their nearby marshes. Ln Area 2, however, canal water flows Into the interior marshes.

In much of the water pumped into the northern Evorglades, concentrations ol: inorganic nitrogen and phosphorus are relalively high. These nutrients are transported in the canals or into the perljheral marshes. Concentrations decrcase sharply within loo metres (330 fcct) or less of the canals, whereas specific conductance remains essentially unchanged within this distance. The shurp decrease In inorganic ni.tropen and phosphorus near the canal edge indicates not uptake in thesc shallow waters.

Concentrations of nitrogen and phosphorus also decrease as water noves through the conservation areas in canals. This decrease is due partly to dilution by rainfall and runolf, and partly to net uptake in the canals and their peripheral marsh.

The large canals of the northern and aatern parta of the conservation. arcas often have relatively low coneentrations of dissolved oxygen which show litt]e filucluation within. 24 hours. Nlso concentrations sometimes appronch anderobic levels near the botton of the canals. This suggests that biological, production is low and that respiration is the dominant metabolic process, Ground water influx may also contxibute to low dissolved oxygen.

Long-term data from an index canal site in the western part of Area 3A, indicate that diel lluctuations i.m dissolved oxygen concentratlons can be cxtremely variablc rrom month to month and at the same season in dicferenc years, Maximum dissolved oxygen saturation at this site exceeded loo percent about 20 percent of the time. Maximum oxygen production occurred in spring and was associated with low water level and flow.

Waler pumped into the conservation araas can aller water quality in the canils by breaking-up water stratification, by resuspending botion scdiments, and by Linfoducing witor of a different chemical charecter. In Area 1 ncar pumping station S-5A in September 1973, ammonia and dissolved oxygen increased and orthophosphate, nitrate, and nitrite decreased af ter pumjing. In Area 3A near pumplng station S-9 in January 1973, ammonia increased and nitrate and dissulved oxygen decreased after pumping. These changes were detectable in canals scveral kilometres downgradient from $s-9$.

Backpumping inlo Conservation Axea 3 added 230 tonnes (25.3 tons) ol 
total nitrogen and 1.8 tomes (2 tons) of Lokal phosphorus from July $197 \%$ through June 1973. Backpumping 50 percent of the total annual cana1 runofl in southeast Florida would add from 900 to 5,600 tonnes (990 to 6,160 tons) of nitrogen and from 9 to 56 tonnes (10 to 62 tons) of phosphorus to the conservation areas.

The bottom scdiments of the Everglades are a sink for nicrogen and phosphorus. They can, however, be a source of these nutrients when anaerobic conditions axist at che water-sediment interface or when botton matoria1 becomes resuspended. With respect to organic carbon and nitrogen, phosphorus is enriched in canal sediments compared with marsh scdiments. $\Lambda 1$ so there is some indication that nitrogen and phosphorus and several trace metals are enriched in canal sediments near pumping stations that drain agxicultural land compared with canal sediments remote from pumping stations.

Thixty-four samples of aquatic plants were analyzed for nitrogen, phosphorus, carbon, copper, lead, and zinc. Except for slightly higher concentrations of phosphorus in plant tissue from two locations where water quality is poor, no significant differences in mutrient and metal concentraLions were evident in aquatic plants collected eithor from remote, relatively undisturbed areas or from areas receiving agricultural runoff.

\section{INTRODUCTION}

\section{Ihe Everglades Environment}

The Everglades is a wide, shallow, peat-filled depression that extends from Lake okecchobee to the mangrove estuaries of Shark River (Fig. 1). It. is bounded on the east by the Atlantic Coastal Ridge and on the wcst by the sandy flatlands and the big Cypress Swamp. It slopes gradually southward From Lake okeechobec. The peat soil, derived from marsh vegetalion, is 2 to 3 metres ( 7 to $10 \mathrm{ft}$ ) deep in the northern Evcrglades, and decreases to 1 metrc or less near its southern extromity in the lower shark River slough.

The Everglades is a vast saw grass marsh interspersed wlth tree islands, sloughs, and wet prairies. It floods seasonally, and often becomes dry during several months in the spring. Water is deepest in the sloughs and becomes shallower progressively to the wet prajrics, to the saw grass massh, and to the tree islands. Difforences in water depth botwcen these communtles are in the order of a few centimetres to scveral decimetres.

Direct rainfall is the prime source of the Everglades' water. Historically the water flowed slowly southward toward the Gulf of Mcxico and Florida Bay, but during perjods of heaviesc rainfall also flowed loward the Atlantic ocean through the transverse glados, During extremely wet ycars Lake Okeechobee overflowed southward. (Parker and others, 2955, P. 332).

The complexion of the Everglades has changed over the years because of drainage, flood concrol, and water mangement practices. The greatest changes in the hydrologlc regime were caused by drainage and flood control. Much of the northern Everglades was drained in the early and mid 1900's for 


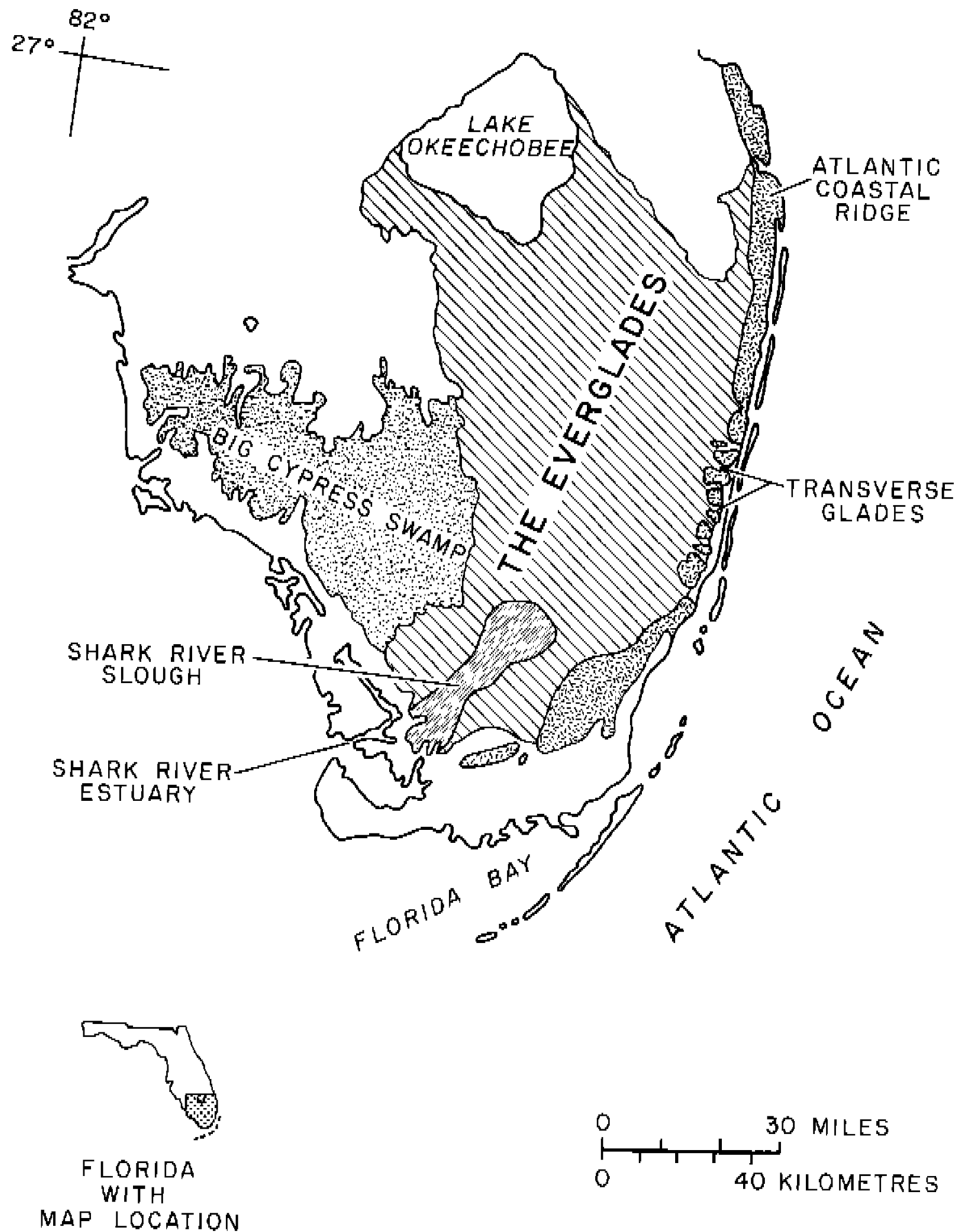

MAP LOCATION

Figure 1.--The Fiverglades. 
In recent years emphasis in water management has been on water contro1 and conservation. Lake okechobec became the prime unit for surface-water storage in the water system of southeast florida, supplenented by the three conservation areas to the south. The conservation arcas serve as replenishment sources lor lower east coast municipalities and agriculture by releases into canals and by underseepage through the Biscayne aquifer. The remaining marshes of the Everglades are now mostly within the conservation areas and Everglades National Park (fig. 2).

Water to sustain the marshes of the conservation areas and Fverglades National Park comes from direct rainfall and from canals which convoy water from Lake Okeechobee and from agricultural lands to the north. Water flows southward down the canals by gravity or is pumped southward into the conservation areas. The three conservation areas are connected by spillway structures that onable water to be transferred directly from Lake okeechobee through Conservation Area 3 and thence to Everglades National Park or to the Mi amf area during drought. In addition, water can be backpumped Irom the cast into Conscrvation Area $3 \mathrm{~A}$ at pumping station $\mathrm{S}-9$. Contro1 structures are operated to maintain the desired water levels for the conservation areas.

Water quality in parts of the Everglades has changed over the years. Pescicldes and polychlorlnated biphenyls (PCB's) now occur in relatively high concentrations in bottom sediment and fish in parts of the Everglades (Mcllerson, 1973). Concentration of dissolved solids are significantly higher in the northern canals and in Conservation Area 2 than in the southern Everghades or the interior of Aren 1. A1though dissolved solids concentraLions have increased in places in the southern Fverglades (Kleln and ouhers, 1974), they have changed little in the northerm Everglades since the 1940's (Gleason, 1974). Concentrations of nitrogen and phosphoras tend to be higher in parts of the northern Everglades than in the south ( $B, G$. Waller and J,E. Farle, 1975).

Increased concentrations of nutrients from agricultural and urban development will change the Evergladas environnent. lucreased amounts of nutrients in aquatic enviromments often cause lush growth of aquatic plants, shifts in food webs, changes in animal populations, and detcrioration of water quality.

Nutrients enter the Everglades manly in rainfall and dry fallout, and in surface water inflow. Whereas rainfall and dry fallout are widely distributed, most surface watex inflow enters at 6 pumping stations in the conservation areas.

A.tfough over 20 elements axe essential for growth and considered nutrients, only a few are required in large amounts. These include carbon, hydrogerl, oxygen, nitrogen, and phosphorus. Carbon, hydrogen, and oxygen are ustially abundant, whereas nitrogen and phosphorus sometimes are not, and limil growth. Because of the importance of nitrogen and phosphorus in controlling aquatic plant growth emphasis in this investigation was placed on those clements. 


\section{CONVERSION OF FACTORS}

The following Factors may be used to convert the Metric units published herein to English units.

\begin{tabular}{|c|c|c|}
\hline Mulliply Metri,c UnIヒs & $\begin{array}{c}\text { by } \\
\text { Length }\end{array}$ & To obtain English Units \\
\hline $\begin{array}{l}\text { millimetres (mm) } \\
\text { metres (m) } \\
\text { metres (m) } \\
\text { kilometres (km) }\end{array}$ & $\begin{array}{l}0.03937 \\
39.37 \\
3.281 \\
0.6214\end{array}$ & $\begin{array}{l}\text { inches (in) } \\
\text { feet ( } \mathrm{t} t) \\
\text { miles (mi) }\end{array}$ \\
\hline & Area & \\
\hline square kilometres $\left(\mathrm{km}^{2}\right)$ & 0.3861 & square miles $\left(\mathrm{ni}^{2}\right)$ \\
\hline & Flow & \\
\hline litres per second $(1 / s)$ & 0.0353 & cubic feet per second $(f L 3 / \mathrm{s})$ \\
\hline $\begin{aligned} \text { cubic metres per second } \\
$\[ \left(\mathrm{m}^{3} / \mathrm{s}\right) \]$\end{aligned}$ & 35.31 & \\
\hline & Mass & \\
\hline tonne $(t)$ & 1.102 & $\operatorname{ton}(\operatorname{shor} t)$ \\
\hline
\end{tabular}



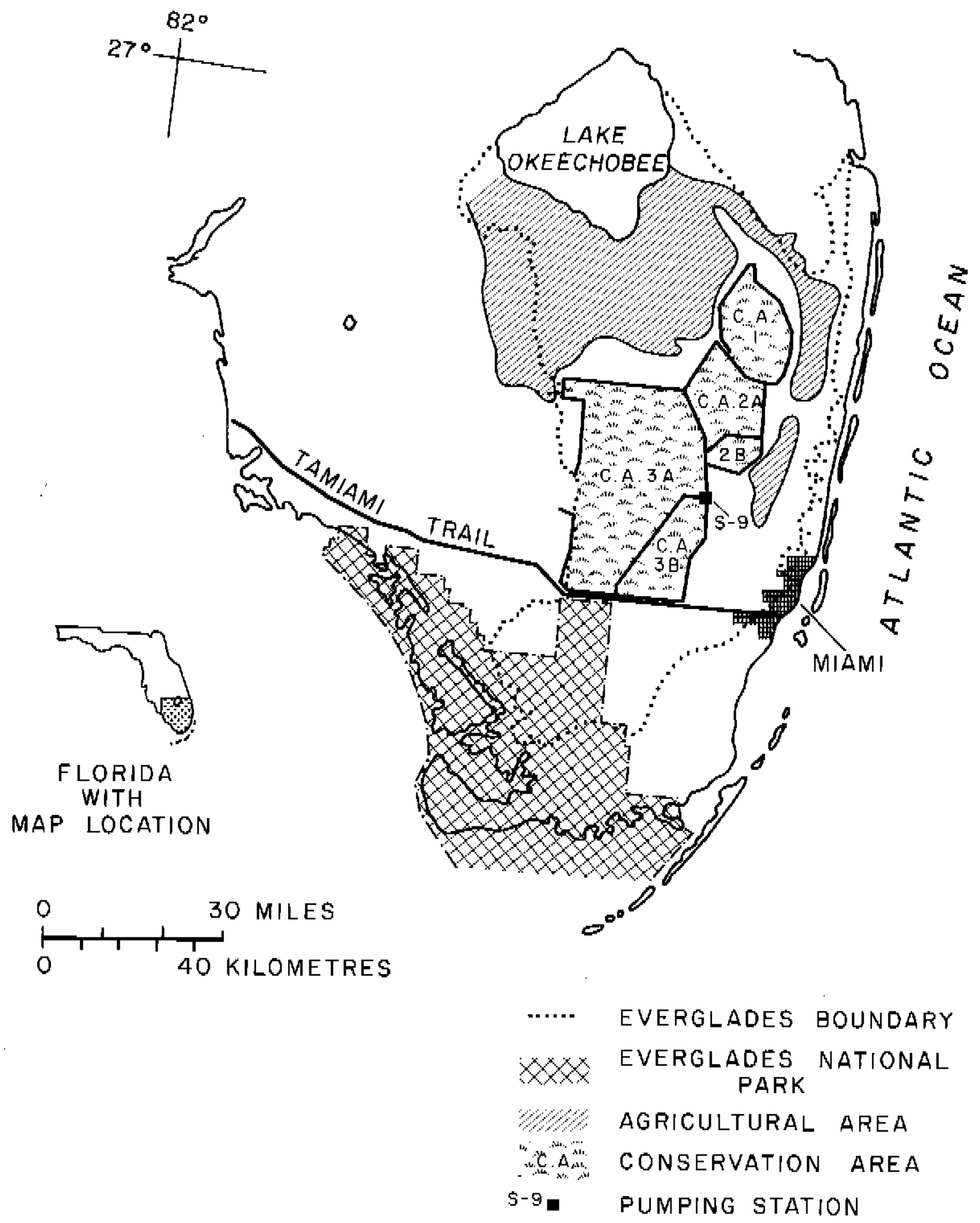

Figure 2,--Everplades boundary, the conservation areas, Fverglades National Park, and areas of agricultural development. 
Plans for more efficient water management in southeast piorida by the Contral and Southern Florida Flood Control District (FCD) include increased backpumping of surplus storm water to the conservation areas (U.S. Army Corps of Engineers, 1968). Recommended construction by the Corps of Engineers calls for completion by 1984. Existing and planned pumping stations are shown in figure 2A. Water can now be pumped into the conservation areas at six stations. Three additional stations have been proposed for pumping water into the conservation areas from the east. These Include:

(1) S-319, with a pumping capacity of $82.7 \mathrm{~m}^{3} / \mathrm{s}\left(2920 \mathrm{Ft}^{3} / \mathrm{s}\right)$ which would backpump surplus water from a $718 \mathrm{~km} 2\left(276 \mathrm{mi}^{2}\right.$ ) area from the C-51 extension of the West Palm Beach Cana1 into Area 1 ( $\mathrm{PCD}, 1.973)$.

(2) 5-320 with a pumping capacity of $33.7 \mathrm{~m}^{3} / \mathrm{s}\left(1190 \mathrm{ft}^{3 / \mathrm{s}}\right)$ which would backpump surplus water from a $309 \mathrm{~km}^{2}$ (1.19 mi2) area to the HI11sboro Canal.

(3) s-330 which would backpump sutplus water from a $169 \mathrm{~km}^{2}$ (65 mi2) area into the southern part of Axea 3.

Large-scale backpumping of water from land east of the conservation areas could affect the Everglades environment if water levels were altered permanently, or if additional loads of nutrients and pollutants were introduced. Vegetation has already changed in farts of the conservation areas whers water lovels have increased by impoundment (Alexander and Crook, 1974; Hagenbuck and others, 1974). The degree that large-scalc pumping would alter the Everglades environment by introducing nutrients and pollutants is not clcar. Although the marshes of the Everglades tie-up large amounts of mutrient: in plant biomass and in sediments, the capacity of the marshes co retain and tolerate additional nutrients is not known.

Part of the water backpumped into Conservation Area 3 would eventually enter Everglades National Park. T'o assure that the quality of the water supplied to the Purk will, not deleriorate, the conmittec on Public Works of the U.S. Senate requested, In Senate Doclument No. 91895, May 26, 1970, that the Corps of Engineers prepare a report within 1 year on the measures taken, and any agreement reached, to midintain good quality in the water delivered to the Park. 'lhe Corps contrited with a private consulting firm Water and Air Rescarch, Inc. (WAR), Gainesville, Florida, to prepare the water quallLy report. One of the recommendations in the WAR (1971) report was that a permanent watcr quility monitoring program be established. In adition, WAR recommended a study on che ecological effects of backpumping of east coast runoff.

At the request of the Corps of Engjncers, the U.S. Geological Survey undertook the reconmended water-quality monitoring and backpumping investigations in the conservation areas. A monitoring network of 26 surface water sites and four bulk precipitation sites was started in July, 1972. invostigations of backpumping were begun in January, 1973. 


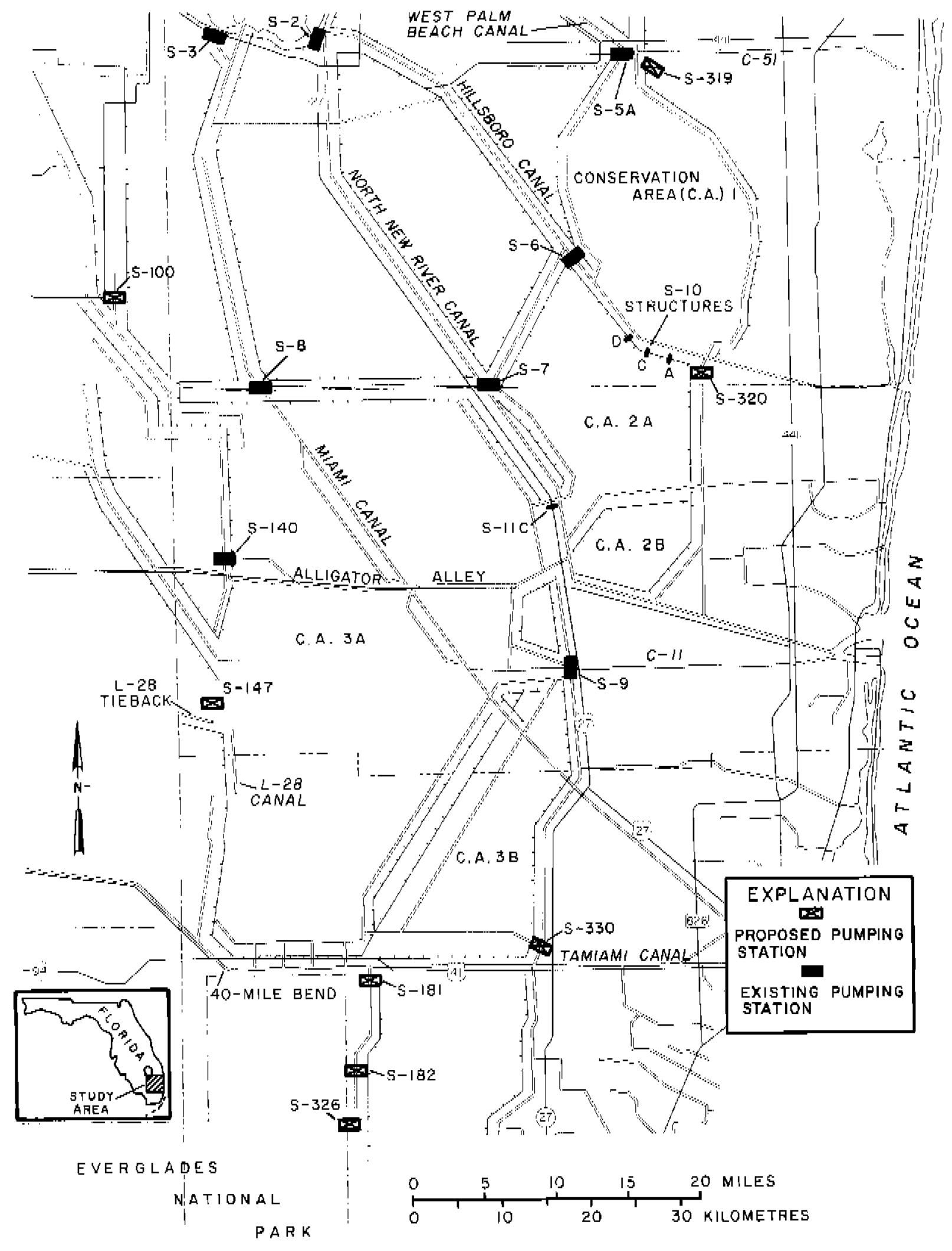

Tigure 2A.--Txisting and proposed pumping stations near the conservalion. areas. 
B.G. Waller and J.E. Earle (1975) summarized the data collected between 1972 and 1974 at the 26 surface water sites and four precipitation. sites. Waller (1975) a1so analyzed nitrogen and phosphorus loading in the conservation areas usIng selccted siteg $i n$ the munforing network. This report summarizes the investigation of backpumping and its effects on the Everglades ecosystem. Acknowledgment is given to the Corps of Enginecrs for support of the investigation.

\section{Purposes and Scope}

lhe purposes of this invegtigation were to make a qualitative assessment of the effects on water quality of pumping watcr into the conservation. arcas, and specifically to evaluate the uptake by scdiment and biota of nitrogen, phosphorus, and sclected trace elements contained in the water.

The scope of the investigation Includes the collection and interpretation of chemical data from water, sediment, and aquatic planty in the vicinity of and remote from pumping activities. Diel (24-hour) studles were included to determine changes in nitrogen, phosphorus, and dissolved oxygen and whether the concentrations of these constituents were affected by pumping. Nutrient transects werc mide co detemine the distribution of water pumped into the areas and to evaluate the location and extent of nitrogen and phosphorus uplake. Dicl studies and transects ware made during high-and-lowwater periods in 1973 and 1974.

\section{Sampling Sites}

Water samples for chemical analysis were collccted in the conservation areas alon transcets and during diel periods for wel and dry seasons. J'ransects extended from perimeter canals into the marshes (fig. 3). Specific conductance, dissolved oxygen, cemperature, inorganic nitroren species and inorganic phosphorus werc measured at selected points along each transet. Dicl studies were carricd out at seven locations in the conservation arcas (fig. 3A). DLssolved oxygen and tomperature were measured every few hours at one or more sites at each locallor. Specific conductance and inorganic forms of nitrogen and phosphorus were measured less frequenciy. Six sites were established near pumping station $s-5 \Lambda$ (Cj.g. 4); elever near pumping station S-9 (lig. 5); three on the rillsboro Canal (one each at the S-10 structures $\Lambda, C, D)$, and four just south of s-10C in Conservation Area $2 \Lambda$ (fig. 3A). An index gtation, $L=28$, was eslablished in the western part of Conservation Area $3 \Lambda$ on Leves 28 canal ahout 19 kilometros (12 miles) north of 40-mile bend (fig. 3A).

In addition to the water samples collected on Lhe transccts and during dicl studies, other water, sediment, and plant samplcs were collected at spccific localions for analysis of inorganic and organic nilrogen, phosphorus, and trace elements. The locations of stallons where bottom scdiments, plant nutrients, and plant biomss data were collected are also shown in figures $3,5 \mathrm{~A}$, and $5 \mathrm{~B}$.

Names of sampling areas with their latitude-longltude or downstream order number are given in lable l. 


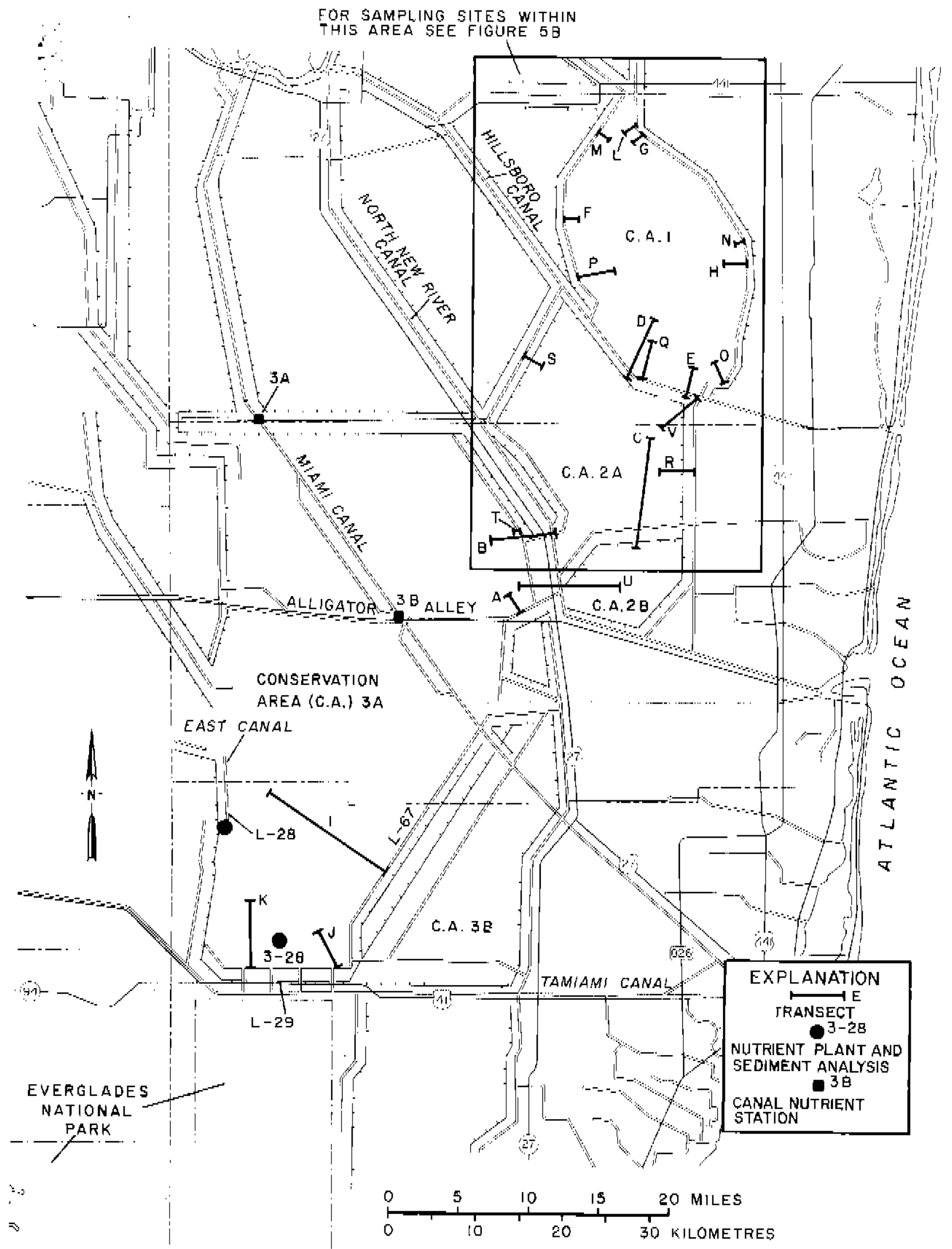

Fj.gure 3.--Nutrient transects, canal nutrient stations, and plant sample areas. 


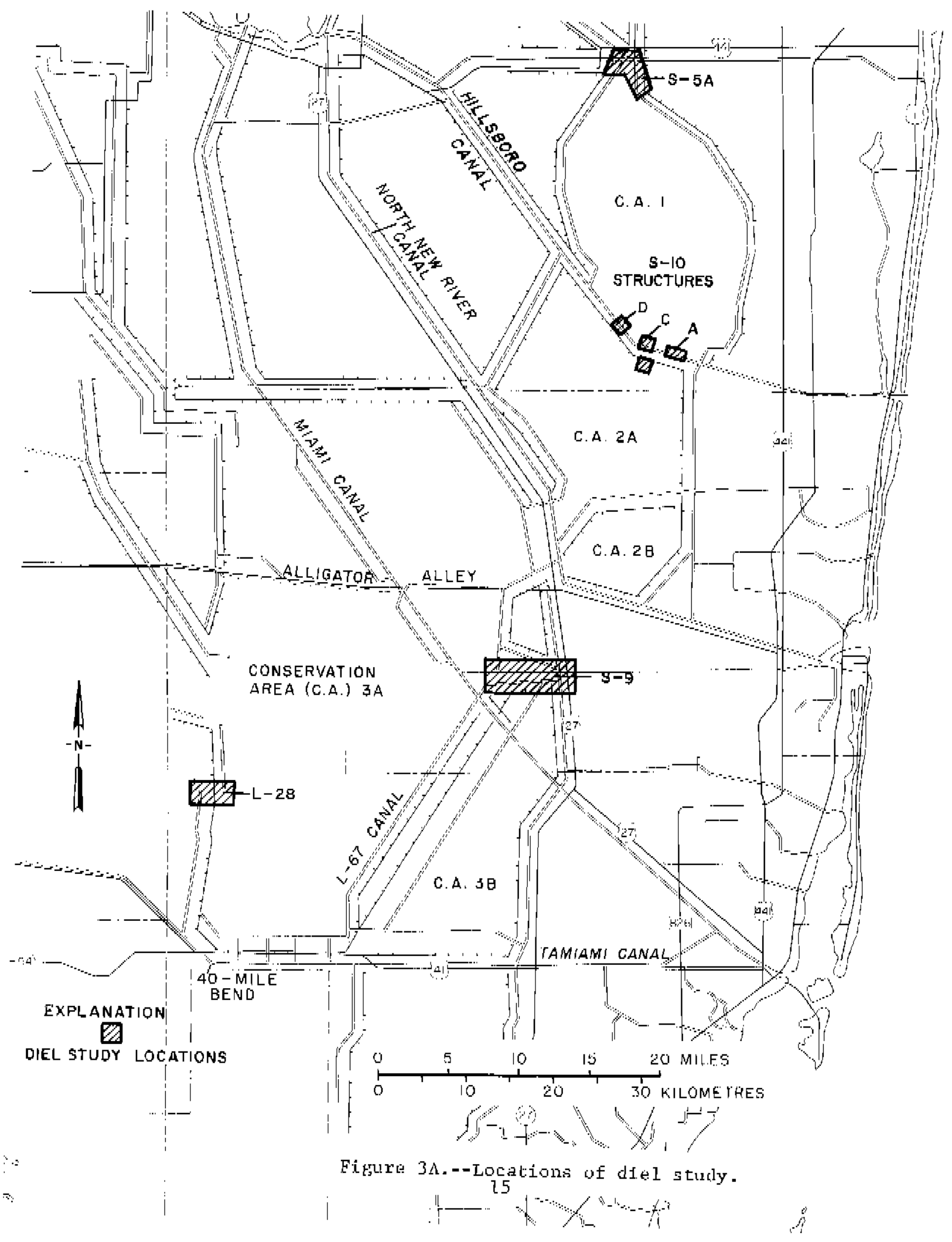




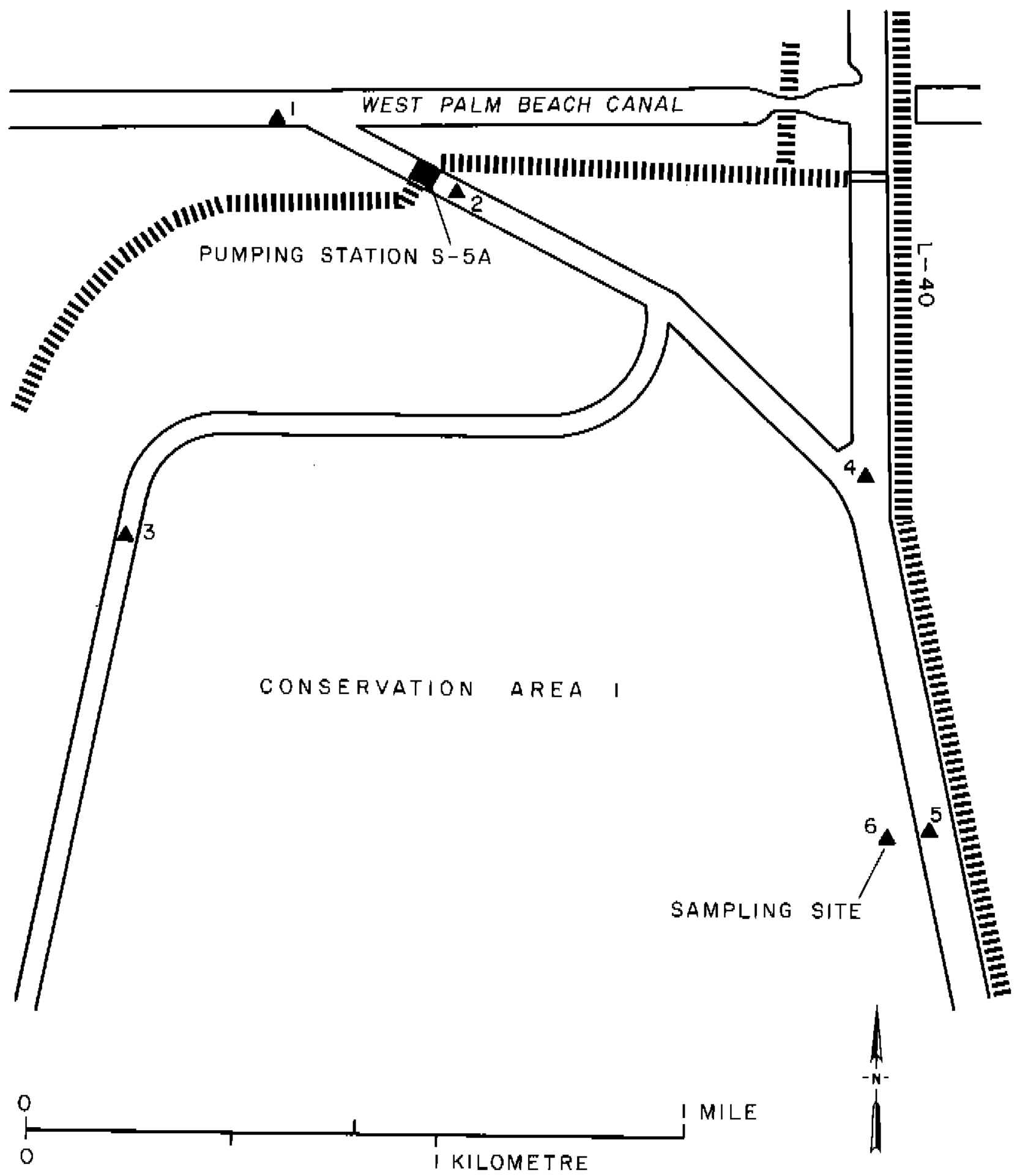

Figure 4,--Sampling sites near pumplng station S-5A. 


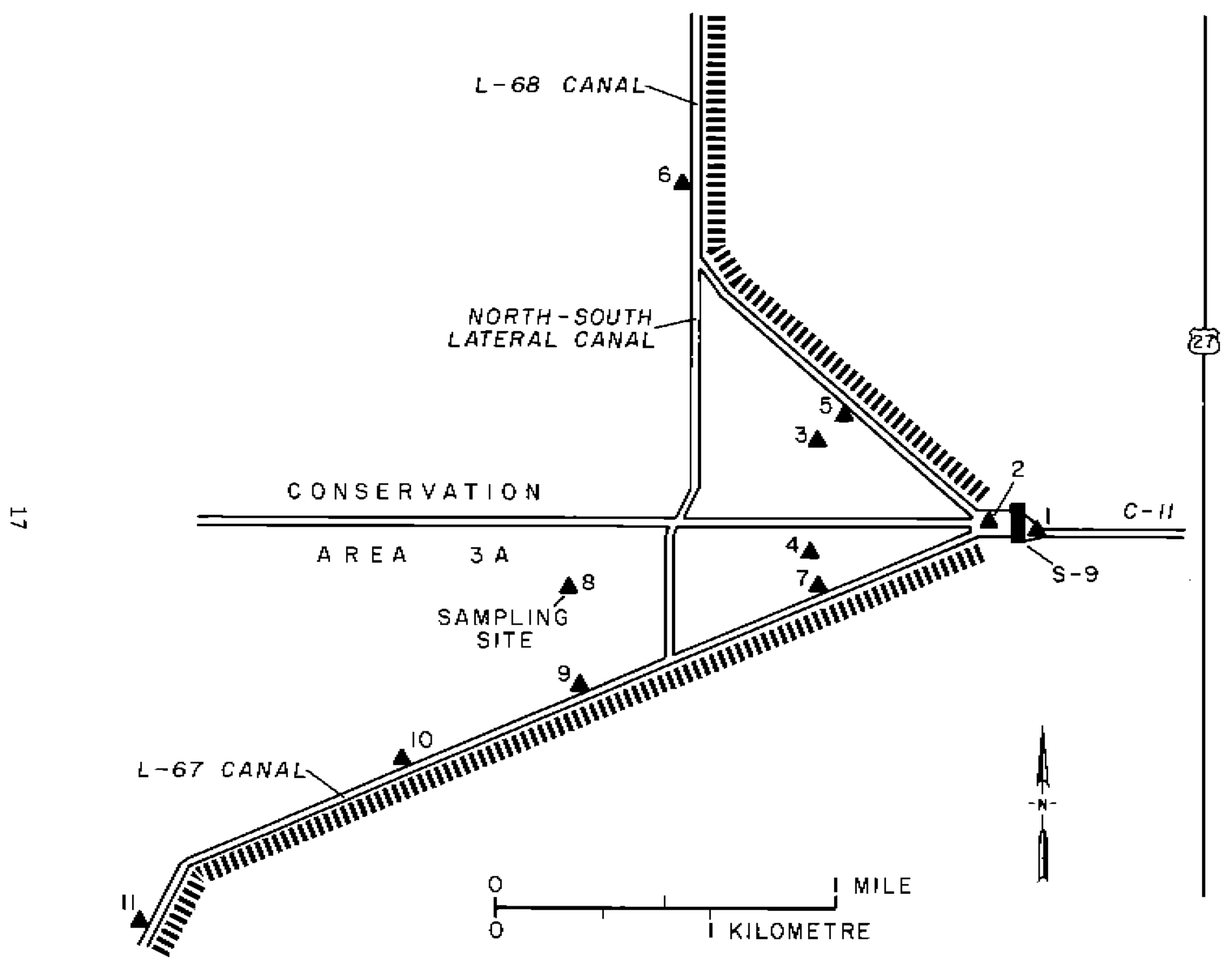

Figure 5.--Sampling sites near pumping station S-9. 


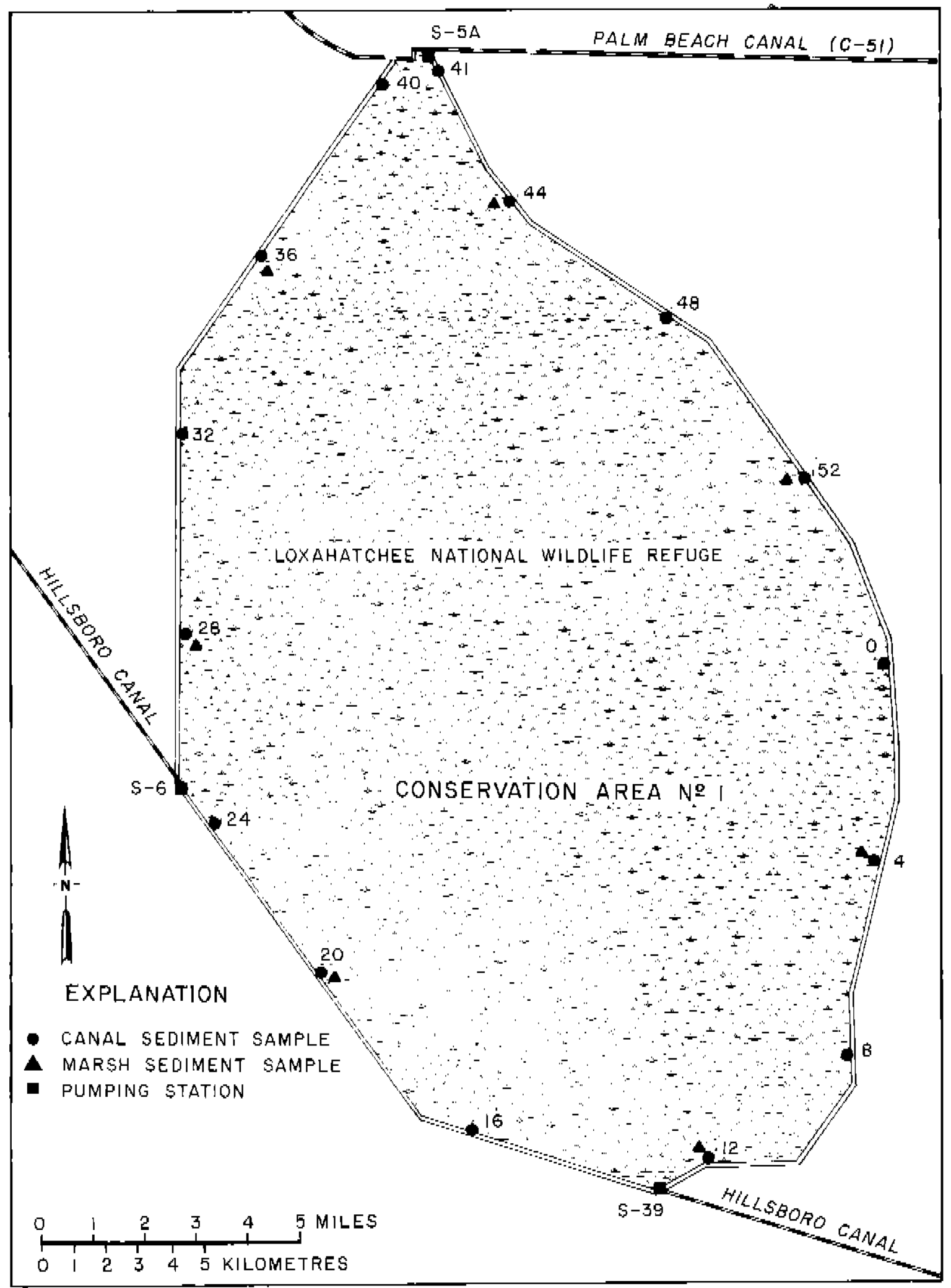

Pigure 5A.-Location of bottom sediment samplea collected in canals and marshes of Conservation Area 1 in February 1974. 


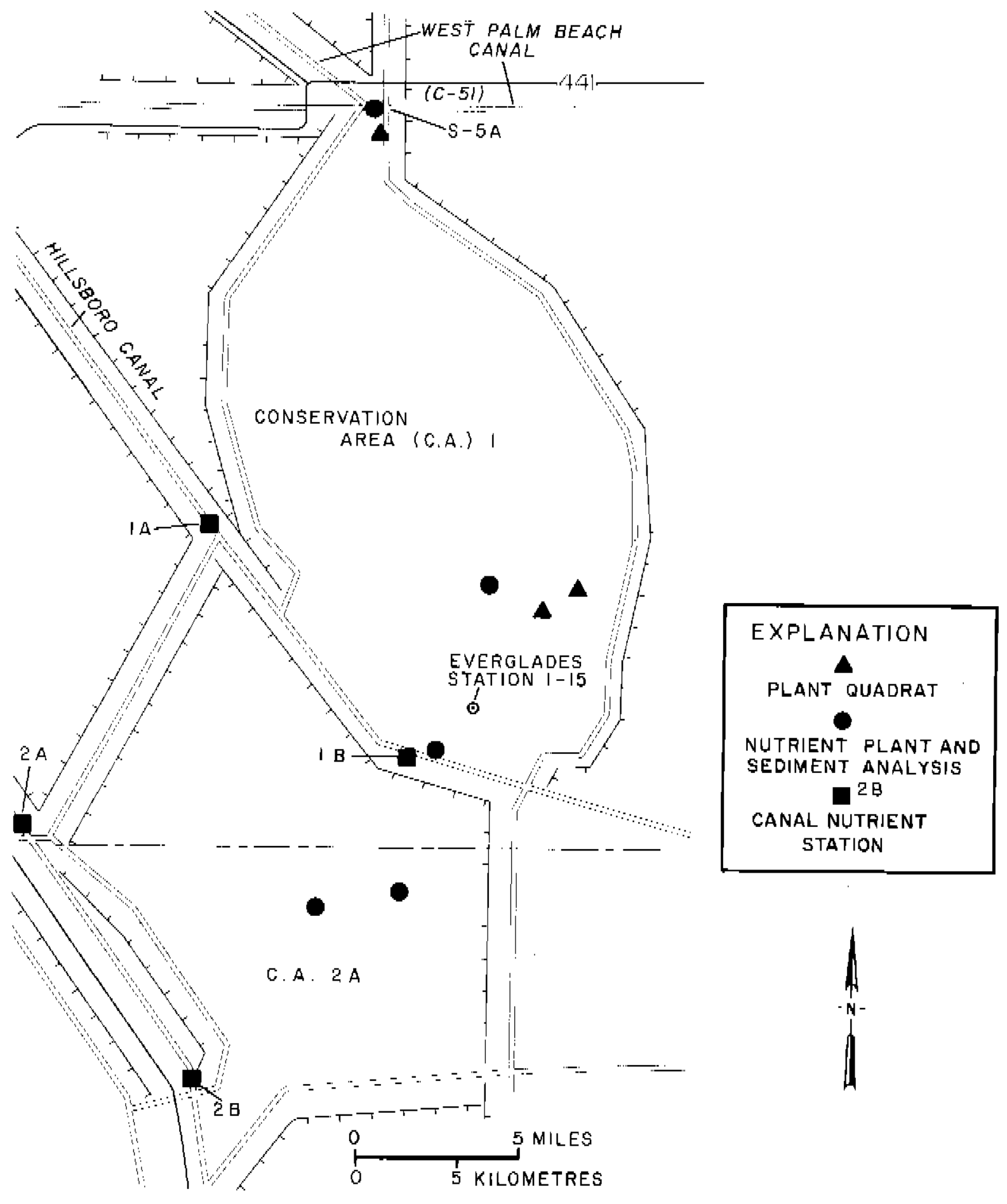

Figure 5b.--Sample areas and stations i.n Conservation Areas 1 and 2A. 
Table 1.-- Names of sampling areas and stations. Locations shown on Figures $2 \mathrm{~A}, 3,3 \mathrm{~A}$ or $5 \mathrm{~B}$.

\section{Description}

Pumping Station S-5A

Pumping Station $5-9$

L-28 Eagt Cana1

Ji. 1 hsboro Canal above $\mathrm{s}-10 \mathrm{C}$

Everglades No. $3-28$

1A Hillsboro Canal above S-6

l. . ITi. L L soro Canal above $5-10$

2A North New River Canal above $\$-7$

2B North New River Canal above S-lic

3A Miamj Canal at 5-8

3b Miami Canal Alligator N1ley

5 miles south of $5-10 \mathrm{C}$

Everglades 5tation 2-17

South-center Area 1 quadrat Site 3

South-center Area 1 quadrat Site 4

South-center Area 1 nutricnt sample

Pumping Station $5-6$

Pumping station $\$-7$

Pumping station $s-6$

Everglades station 1-15

L-67A Canal
Downstream order number or latitude-longitude

02278450

02285400

255600080484500

262400080230000

02289043

02281200

2624000802300

2620000803210

02284501

02286700

2608500803810

2620050802050

02284642

2627300801600

2626000801700

2627300801900

02281200

262000080320500

02286700

02281295

25462008039500 
Nitrogen and Phosphorus Concentrations at Selected Sites

Data were collected monthly from July 1972 Lo July 1974 at five pumping stations to characterize concentrations of nitrogen and phosphorus pumped into the conservation areas (B. G, Waller and J. E. Earle, 1975). Lhese data are summarizcd in Table 2. Median concentrations of nitrate, milrite, amonia, inorganic nilrogen, organic nitrofen, total nitrogen, and total phosphorus are given. For comparison median concentrations for samplcs collected during thls period at three marsh sitcs and at an index site remotc from pumping stations are also shown on Table 2.

Median concentrations of inorganic nitroges, ranging from 0.13 to 0.75 $\mathrm{mg} / 1$ (milligram per ILlre), were higher at the pumping stations than at the throc marsh sites or aL the L-28 canal inclex site, where they ranged Erom 0.04 to $0.13 \mathrm{mg} / \mathrm{l}$ (Lable 2). Ammonia was the most abundant form of Lnoxganic nitrogen at 3 of the pumping stations, the marsh sites, and L-28 (table 2). The relatively high concentrations ol ammonia at $s-6(0.39 \mathrm{mg} / \mathrm{l})$ and $\mathrm{s}-9$ $(0.41 \mathrm{mg} / 1)$ probably result from high ammonia concentrations in ground wator which seeped into the fecder canal during pumpjng. Also, at pumping station s-9, dissolved oxygen is often near zero. Under such conditions other forms of inorramlc ritrogen would tend to be convertad to emmonla. Freiberger (1973) reported marked decreases in dissolved oxygen and nitrate concentrations and increases in ammonia concentration in Conservation Arca $3 \mathrm{~A}$ durling backpumping at pumping station $\mathrm{S}-9$. Nitrate was virtually absent at $\mathrm{S}-9$, but exceeded $0.10 \mathrm{mg} / 1$ at the other pumping stations. It was the most abundant form ol inorganic nitrogen at pumping stations $5-5 \mathrm{~A}$ and $\mathrm{S}-8$. For comparison, median nitrate concentrations were cero at the marsh sites, presumably because this form of nitrogen is readj.ly taken up by organisms in the marsh.

Median concentrations of organic nitrogen and total nilrogen were slightly lower at the L-28 canal site and 2 marsh sitcs, $3-28$ and $1-15$, than at pumping stations $\mathrm{S}-5 \mathrm{~A}, \mathrm{~S}-6, \mathrm{~S}-7$ and $\mathrm{S}-8$. The median value at marsh site $2-17$ (Conscrvation Area 2), however, is in the same range as those at the pumping st.ations.

Median concentrations of total phosphoris werc higher at jumping stations $\mathrm{S}-5 \mathrm{~A}$ and $5-6(0.05 \mathrm{mg} / \mathrm{l})$ than at the other pumping stations, at $\mathrm{L}-28$, and at the marsh sites $(0.01-0.02 \mathrm{mg} / 1$ ) (table 2).

\section{Nitrugen and Phosphorus Uptake in Canals}

Dowtistreanl changes in nitrogen, phosphorus, and specific conductance were measured in 3 canals in the conscrvation areas; the Hillsboro canal, the North New River Canal, and the Miami Canal, A pair of sites in cach canal was sampled monthly Irom September 1972 to June 1974. The si.tes in each canal wexe about 16 kilometres (lo milcs) apart and are shown on figures 3 and $5 \mathrm{~s}$.

In the canals specific conductance decreased downstream 1. percent per kilometre (2 percent per mile), on the avarage, whereas total phosphorus and 
Table 2.--Median concentrations of nitrate, nitrite, ammonia, organic nitrogen, total nitrogen, and total phosphorus in mg/1 (as $\mathrm{N}$ or P) at pumping stations S-5A, S-6, S-7, S-8 and S-9; at cana1 L-28 remote from pumping stations and agricultura1 activity; and at marsh sites 3-28, 1-15, and 2-17. (Data collected monthly between July 1972 and July 1974 . Location of sites shown on 2.A or 3.$)$

Inorganic-N

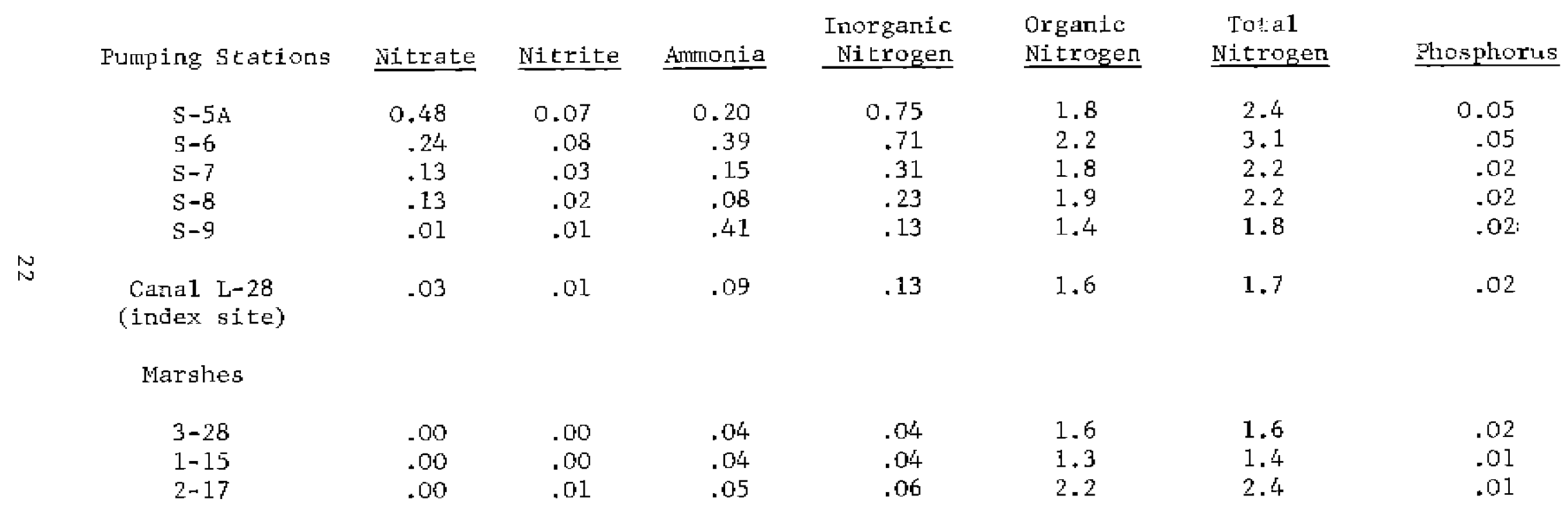


jnorganic nitropen decreascd 3 percent and 4 percent per kilometre (4 percent and 6 percont per mile) (table 2A). The decrase in specific conductance indicates dilution from tainlali on the marsh and canal. The decrease in phosphorus and nitrogen Indicates: 1) dilulion from rainfall plus uptake; or, 2) addition lrom rainfall plus uptake in excess of the addition. Rafnlial. contributes large loads of nij.trogen and phosphorus to the conservation areas, but much of this is retained in the murshes (Waller, 1975). Concentrations of Inorganic nitrogen and phosphorus in the watcr of the marshes are typically lower than in the water of the canals in the consexvation areas (Lable 2 ). The decrease in nitrogen and phosphorus downstream in these canals, then, probably reflects di Jution plus uptake.

\section{Nitrogen and phosphorus Uptake in Marshes}

5 amples were collected along twency-two transects during high watex (September ${ }^{2} 1973$ ) and Low water (January 1974) periods (fig. 3). The purpose: of the transects was to evaluate the movement of water from the canals into the marshes, and the changes in water chemistry caused by this movement. Each transect extended from a canal, or across a canal, into the marshes of the conscrvation areas. Inorganic forms of nitrogen and phosphorus, specilic conductance, dissolved oxygen, and temperaturc were measured at selected distances along the transects (Basic data $\Lambda$ ).

Specj.fic conductance, which is not readily altered by biological activity, was used as an indicator of water movement. Canals in the northern paxts of the conservation axeas tend to have relatively high conductance, often above 1,000 pmhos/cm (micromhos per centimetre). Because canal waler has higher conductance than rainfall (rain water is usually below 1,00 umlos/cmil the movement of the cand water into the marshes cun be estimatad from the specific conductance of water in the marshes. Concentrations of dissolved oxygen and the inorgani.c forms of nitrogen and phosphorus, however, are much more susceptible to biological changes than is specific conductance.

Around much of the perimeter of Conservation Area 1 specific conductance decreased to that of the interior (100-150, umhos/cm) within s few kilometres indicating that canal water was a minor part of the water al those distances (figs. 6 and 7). In the southwest, however, specific conductance values half that of canal water were measured at several kilometres in the marsh, indicatIng that water from canals, mixed with rajn water, exlended farther into che intcrior in the southwest than in other parts of Area 1. Avcrage specilic conductance for al1 marsh sites in Area 1 was only 248 , nmosicm in September 1973 (table 3).

While canal water did not flow into the marshes of Conservation Area 1 . much beyond scveral kilometres, it did penetrate into the interior of Conservation Area $2 \Lambda$ and alter quality there. Specific conductance, for example, was only slightly higher II 1972-73 in the Hillsboro Cana1 at: $s-6(1,340$ pmhos/ $\mathrm{cm})$ than in the marshes near the center of Aroa $2 \mathrm{~A}(1,150$ durhos/cm).

Data are not avaibalo to adequalely evaluate the effoct of canal water on specific conductance in Area 3. 'Jhee transcets in september 1973 Lndicate, however, that the spread of canal water outward from L-67 and L-29 canals into 
Table 2A.--Changes in nilrogen (N) and phosphorus (P) in milli.grams per Iftre and specific conduccance in micromhos per centimetre at $25^{\circ} \mathrm{C}$ at paired sampling sites on canals jin the conservation areas. (The values represent monthly averages of 24 samples except $2 \Lambda$ which had 23 samples) over the period September 1972 to June 1974 . Tocation of sites shown on Figures 3 and $5 \mathrm{~B}$.

Dist.

Down-

stream

Site Kilometres

$\underline{\mathrm{NO}_{3}-\mathrm{N}} \quad \mathrm{NO}_{2}-\mathrm{N} \quad \mathrm{NH} 3-\mathrm{N}$

Inor- Total

Specifi.c

ganic $\mathrm{N} \quad \mathrm{P}$

Cond.

umlios

$1 \mathrm{~A}$

11

0.64

0.10

0.44

1.2

.12

1270

$1 \mathrm{~B}$

$\frac{.11}{-83} \quad \frac{.02}{-80}$

$\frac{.10}{-77}$

\begin{tabular}{l}
.23 \\
\hline-81
\end{tabular}

$\frac{.04}{-66}$

$\frac{1000}{-22}$

$2 \mathrm{~A} \quad 13$

$2 \mathrm{~B}$

$\begin{array}{r}.37 \\ .10 \\ \hline-73\end{array}$

.04

.19

.60

.04

1.150

$\begin{array}{r}.27 \\ \hline-55\end{array}$

$\frac{.03}{-25}$

$\frac{1000}{-13}$

3A 24

$3 \mathrm{~B}$

\begin{tabular}{lll}
.70 & .05 & .12 \\
.46 &. .02 & .08 \\
\hline-33 & -60 & -33
\end{tabular}

.87

.03

930

Percent change

Average percent

change

$-63$

$-63$

$-44$

$-57$

$-41$

$-18$

Percent change

per kilometro

$-4 \quad-4$

$-3$

$-4-3$

$-1$ 


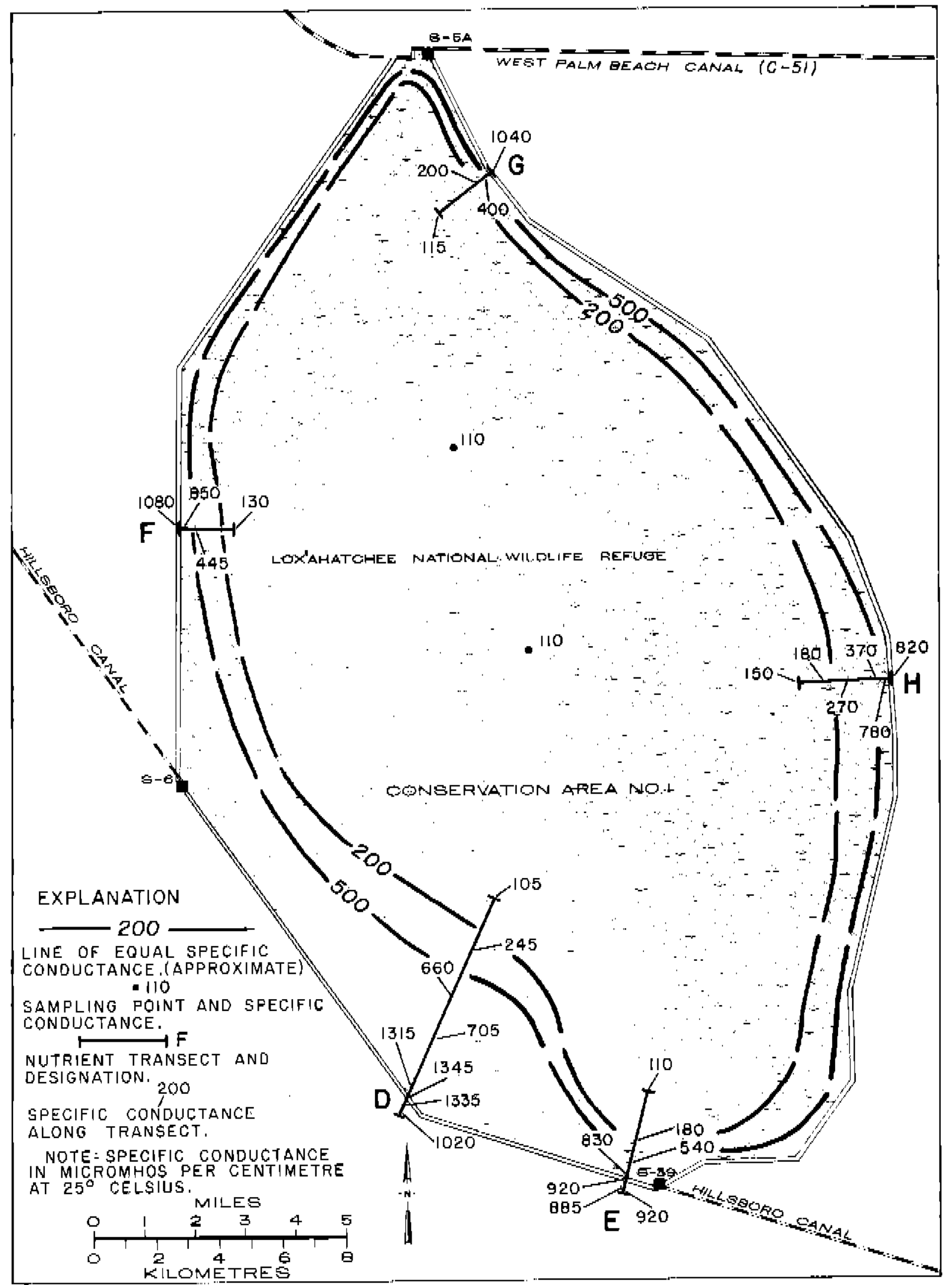

Figure 6,--specific conductancc in Conscrvation Area J. in September 1973 (high water) 25 


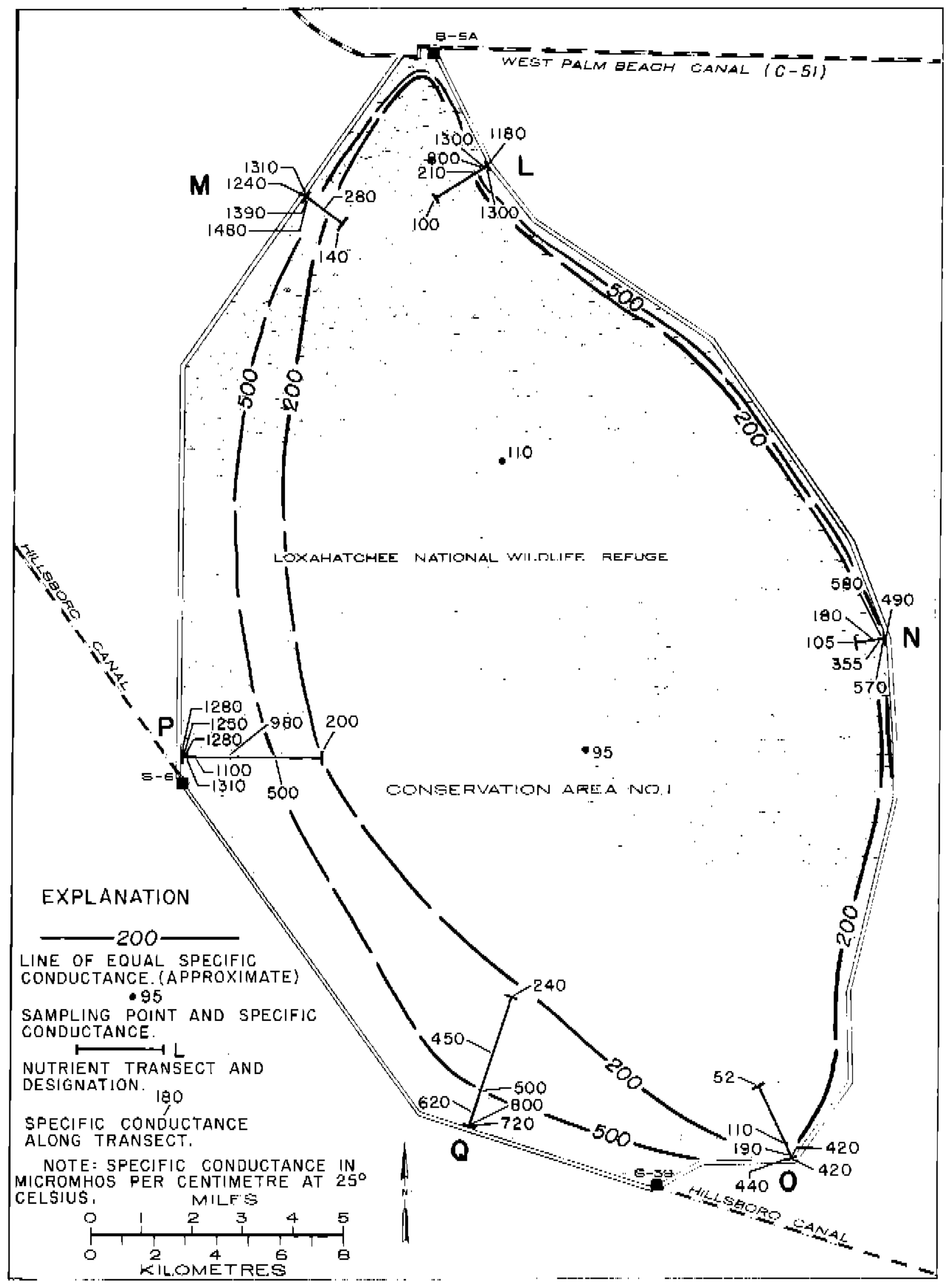

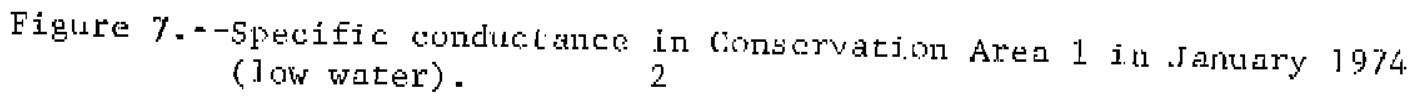


Iable 3,-- Hverage concentrations in $\mathrm{mg} / \mathrm{l}$ of No3, $\mathrm{NO}_{2}$, $\mathrm{NH} 3$ (as $\mathrm{N}$ ) and $\mathrm{PO}_{4}$ (as $\mathrm{P}$ ) in the conservation areas and adjacent casals on 10-11 september 1973 and 16-17 January 1974. (Specific conductance in micromnos/cm at 25 C.)

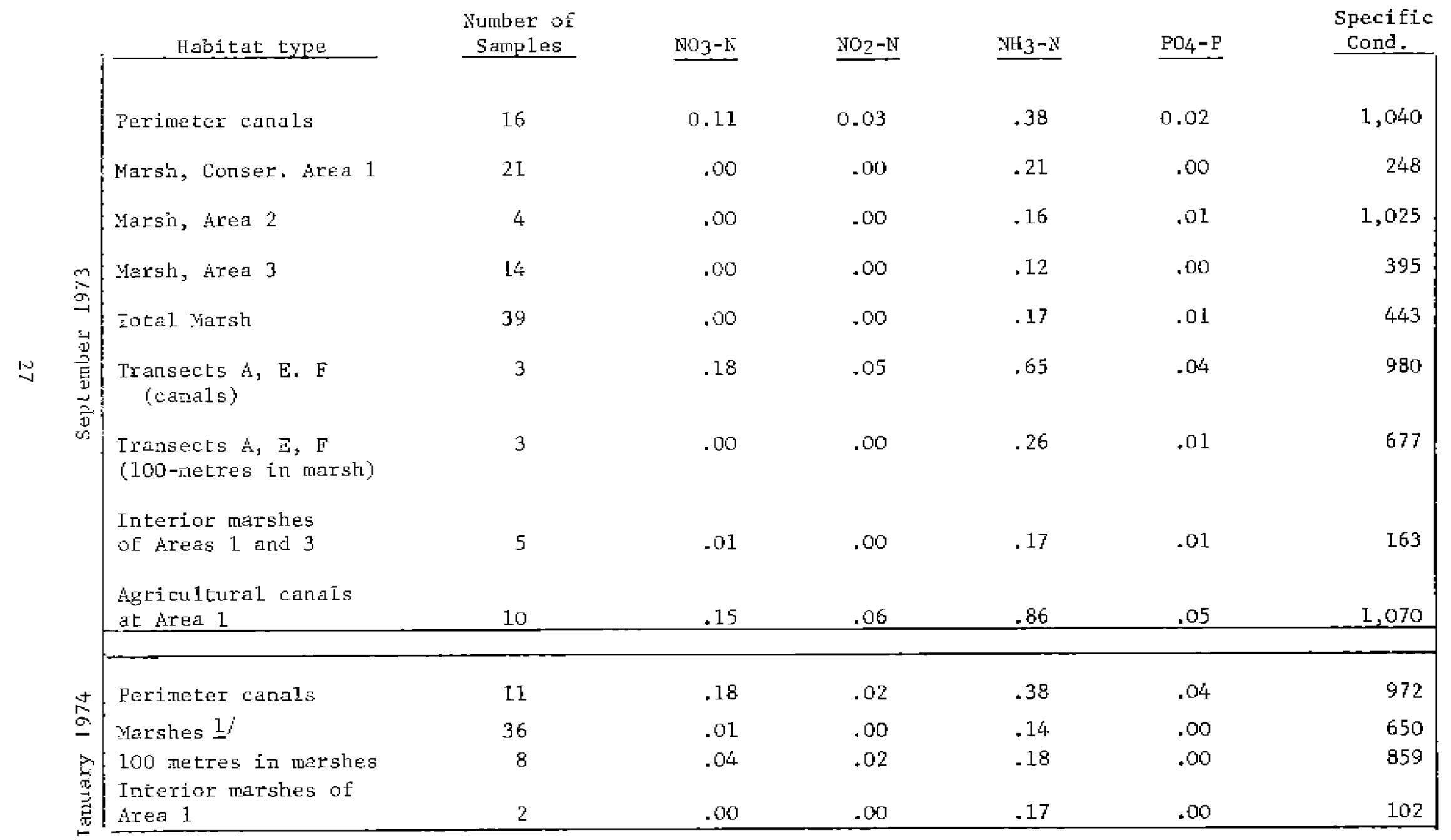

1 includes al1 reasurements beyond loo metres from a canal. 
the marghes in the south part of Area 3 A was slight. In the northeast, however, canal water spread farther. (Baslc data A).

Concentrations of phosphorus and inorganic nitrogen tended to decrcase to marsh background levels within 100 metres (330 leet) of the perimeter canals (figutes 8-1T and Basic Data A). Within this distance changes in spccific conductance tended to be relatively small. The high spectlic conductance indicates dilution is not an important factor in the decrease in phosphorus and inorganic nitrogen.

Ammonia (NH3-N) was the most abundant form of inorganic nitrogen In both wet and dry seasons. In Soptember 1973 and January 1974 ammonia averaged $0.38 \mathrm{mg} / \mathrm{L}$ in the perimeter canals. In the marshes $\mathrm{IL}$ averaged $0.17 \mathrm{mg} / \mathrm{l} \mathrm{in}$ Septembar, and $0.14 \mathrm{mg} / \mathrm{I}$ in January. Within 100 metres of the perimeter canals ammonia declined to loss than 50 pexcent of the concentration in those canals (table 3).

N.trate $\left(\mathrm{NO}_{3}-\mathrm{N}\right)$ concentratlons in the perimeter canals averaged $0.11 \mathrm{mg} / 1$ in septcmber 1973 and $0.18 \mathrm{mg} / \mathrm{l}$ in January 1974 . It was only occasionally detected boyond 100 metres ( 330 fect) from the canals.

Nitrite $\left(\mathrm{NO}_{2}-\mathrm{N}\right)$ was cletected in about 30 porcent of the canal water samples, and averaged 0.03 and $0.02 \mathrm{mg} / \mathrm{I}$ in septomber 1973 and January 1974. It was scldon delected in the intcrior maxshes.

Orthophosphate ( $\mathrm{PO}_{4}-\mathrm{P}$ ) averagcd $0.02 \mathrm{mg} / \mathrm{l}$ and $0.04 \mathrm{mg} / \mathrm{l} \mathrm{in}$ the perimeter canals in September 1973 and Jumuary 1974 (table 3). Concentrations fo the marsh averaged $0.01 \mathrm{mg} / 1 \mathrm{in}$ September and less than $0.01 \mathrm{mr} / 1 \mathrm{in}$ January. In Septcmber. 1973 orthophosphate apparently penetrated farther into the marshes. Concentrations above $0.01 \mathrm{mg} / \mathrm{l}$ wore recorded in 43 percent of the samples and some of these hligher values wore at distances more than a kilometre from a cant. Tn Jamiary 1974 , valucs did not exceed $0.01 \mathrm{mg} / \mathrm{l}$ beyond 100 metres (330 feet) from the canals.

Concentrations of dissolved oxygen tencled to incroase from canals into the marshes (figs. 8-9). In January 1974, for example, concentrations of 5 canal samples in Area 1 avcraged $2.9 \mathrm{mg} / 1$, as compared with $5.9 \mathrm{mg} / 1 \mathrm{In}$ the marshes at the end of the transccts. The coneentrations at the center of Arca l at that time averaged $7.5 \mathrm{mg} / 1$. The increase in dissolved oxyren with distance from canals ma be attributed to an increase in photosynthetic pxoduction, lhotosynthesis in eanals could be restricted by influx of anaerobic ground water, rapld water movement, water depth, the sbsence of large stands of aquatic plants or other factors.

\section{Di.e1. Chemien1 Changes}

Dissolved Oxyren

Oxygen is replenished to the waters of the Tverglarles by photosynthesis of submerged aquatic plants, and it is depleted by respiralion of these plancs and other organisms. Oxygen also enters and leaves the waler by diffusion to 

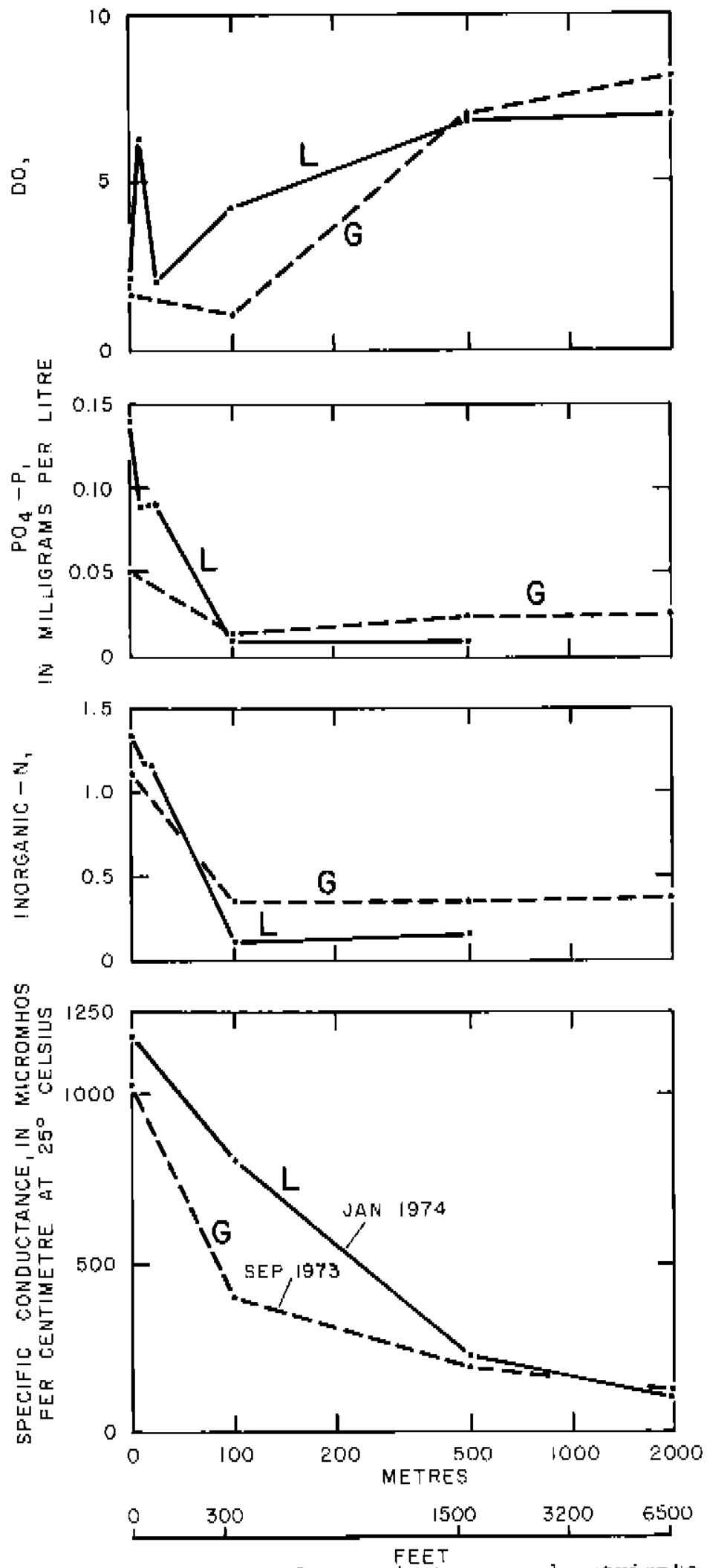

Figure 8,--Chandes in specific comductance and nutrients along transect.s C (September 1973) and L (Jaruary 1974) in. the northern part of Conservation $A$ rea 1 . Zero to 100 metres a comventional sesle; 100 to 2000 metros is a log scale. 29 

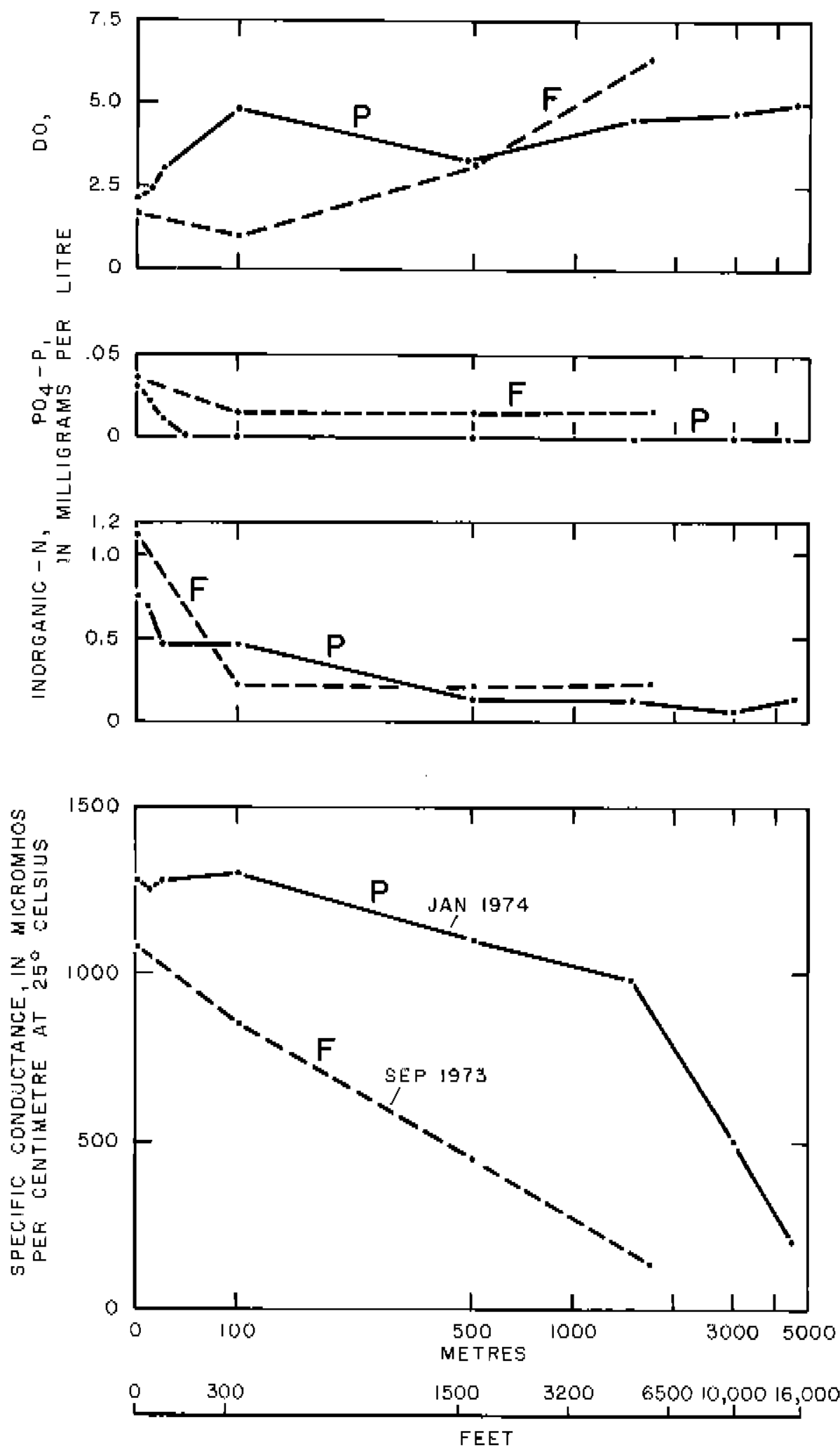

Figure 9,-Changes in specilic conductance and nutrients along transects F (Septcmber [973) and F. (Jamuary 1974) in the westcrn part of Consistation Area l. Zero to 100 metres ls a convontional scale; 100 to 5000 metres is a log soale. 


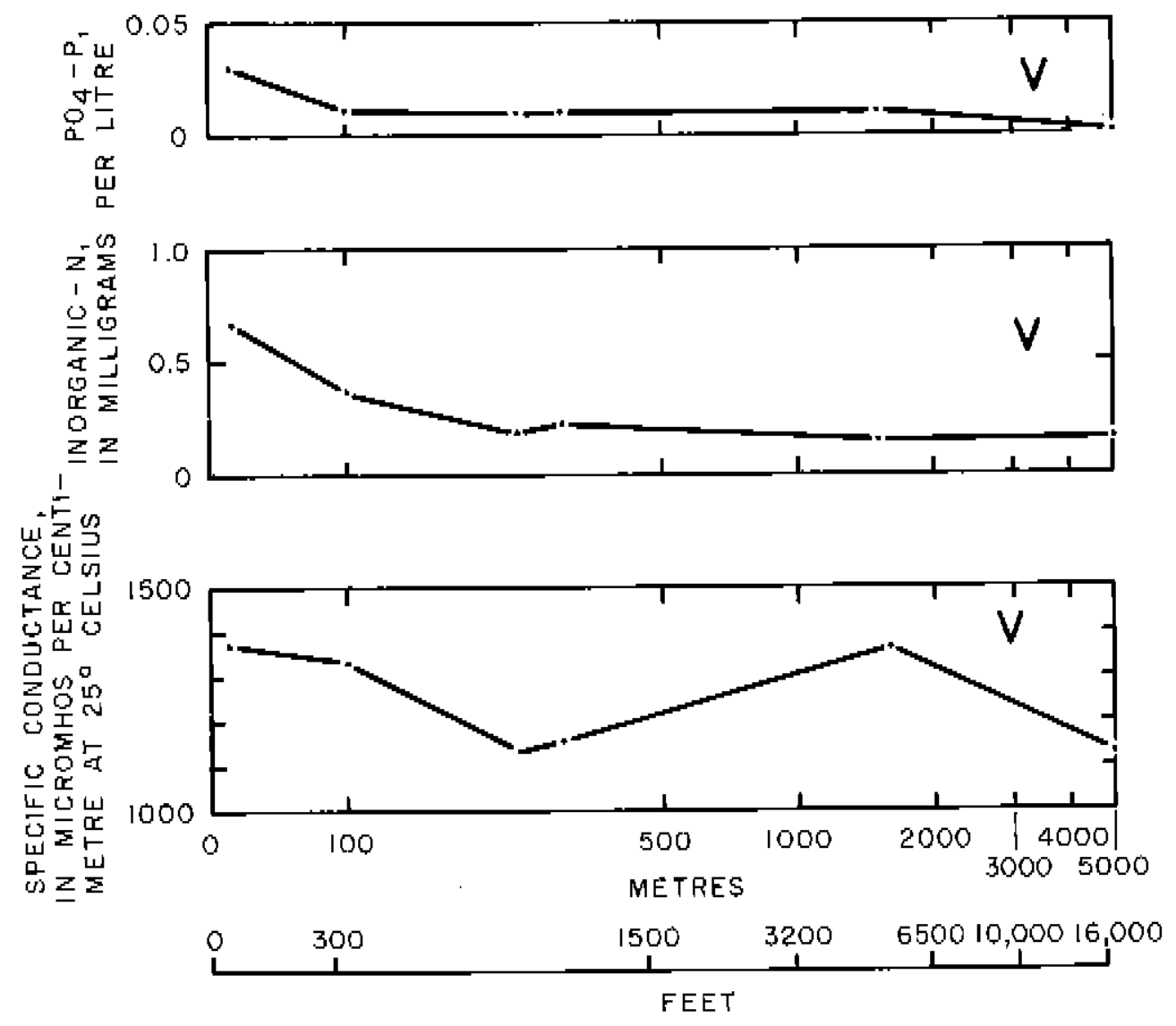

Figure 10.--Changes in specific conductance and nutrients along transect $\checkmark$ in Conservation Area 2A, Jantiary 16, 1974. Zero to 100 metres is a conventional scale; 100 to 5000 metres is a log scale. 


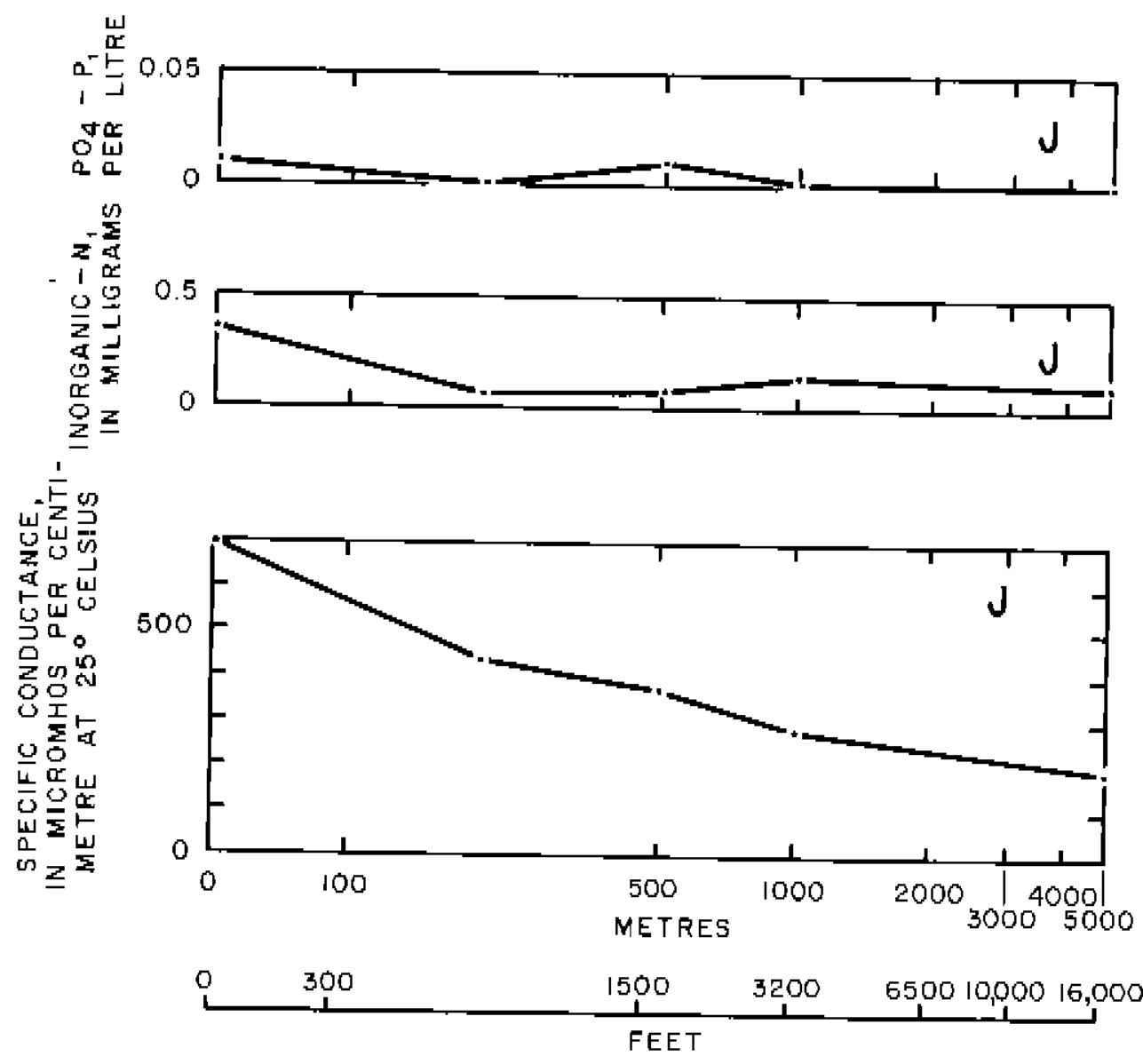

Figure 11.--Changes in specific conductance and nutrients along transect $J$ in Conservation Area 34, Soptember 11, 1973. Zero to 100 metres is a conventional scale; 100 to 5000 metrcs is a log scale. 
and from the atmosphere. Changes in dissolved oxyger over a 24-hour cycla reflect, to a large degree, biological metabolism--resplration and photosynthesis. Large increases in dissolved oxygen during the day usually indicace photosynthetic production; dectesses in concencration at night usually indicate oxygen uptake by respiring organisms.

Fmergent plants producc and relcase oxygen mostly above the water surface. The submerged plants, partjcularly the periphyton, produce and release oxygen into the water. Thus, measurements of changes in clissolved oxygen in the water. reflect primarily the metabolism of submerged organisms.

Diel studies were made at four locations In the conservation areas (fig. 3A). Two of thesc, 5-5A and the Hillsboro Canal at S-10A, $C$, and $D$, receive water of relatively poor quality pumped from agricultural areas to the north. At the third location, $s-9$, water of better quality is pumped from the cast. The index locatjon, L-28 canal, is remote from pumping and farming activitj,cs,

The concentration of dissolved oxygen in the large canals near $\mathrm{S}-5 \mathrm{~A}$ and S-9 and in the Hillsboto Canal fluctuated 1Ittle over 24 hours (Basic Data B, $\mathrm{C}, \mathrm{D}, \mathrm{E})$. In canals near $\mathrm{S}-5 \mathrm{~A}$ uxygen saturation near thc surface ranged from about 60 to 70 percent on January 16-17, 1973 , and about 10 to 30 percent on Sejtember 10-11, 1973. Ln the Hillsboro Canal (January 1974) and in the canals near 5-9 (January 1973) saturation near the surface fluctuatcd from about 40 to 70 percent. The concentration of djssolved oxygen decreased with depth; in the Hillsboro canal, for cxample, saturation ranged from about 30 to 55 percent near the bottom (2-3 metres). At $\$-5 \Lambda$ conditions were nearly anaerobic close to the bottom. For comparison, saturallon of dissolved oxygen near the surface ac the index stacion, L-28 Cana1, ranged from about 60 to 100 percent on Jantuary 16-17, 1973 and from about 35 to 75 percent on September 10-11, 1973 . Dissolved oxygen decreased with depth on september 10-11, 1973 and near the bottom ranged betwcen about 25 and 45 percent saturation over 24 hours.

The relatively small fluctuations in dissolved oxygen in the laxge canals near S-5A and S-9, and in the Hillsboro CanaI (S-10A, C, D) indicato a photosynthetic production near zcro. This low productivity may be attribuled to waler movement which tends to inhibit large plankton blooms, and to deep water which restricts sunlight penetration and inhibits benthic plant production. The low dissolved oxygen in bottom waters indicates respiratory consumption of oxygen. Ground water influx and other factors may also contribute to low dlasolved oxygen near the bottom of canals.

A Lew diel studies were made in the marshes of the northern and eastern Everglades. Near $s-10 \mathrm{C}$ in Conservation Area $2 \mathrm{~A}$, measurements were made on Jamary 16-17, 1974 at 15,30 , and 800 metres from the collector canal. The maximum daytime concentration of dissolved oxygen (65 percent) occurred at 15 metres (50 feet) and the minimum (20 percent) occurred at 30 metres (100 feet). At 800 metres $(2,640$ feet) In the marsh saturation reached 55 porcent, Conditions at the 3 marsh $\theta i t e s$ were nearly anaerobic by carly morning (fig. 12). At a secont localion, near S-9, maximum oxygen saturation at 3 marsh sites on January $16-17,197.3 \mathrm{ranged}$ between 72 and 105 percent, while minimum saturation ranged between 15 and 78 percent. 


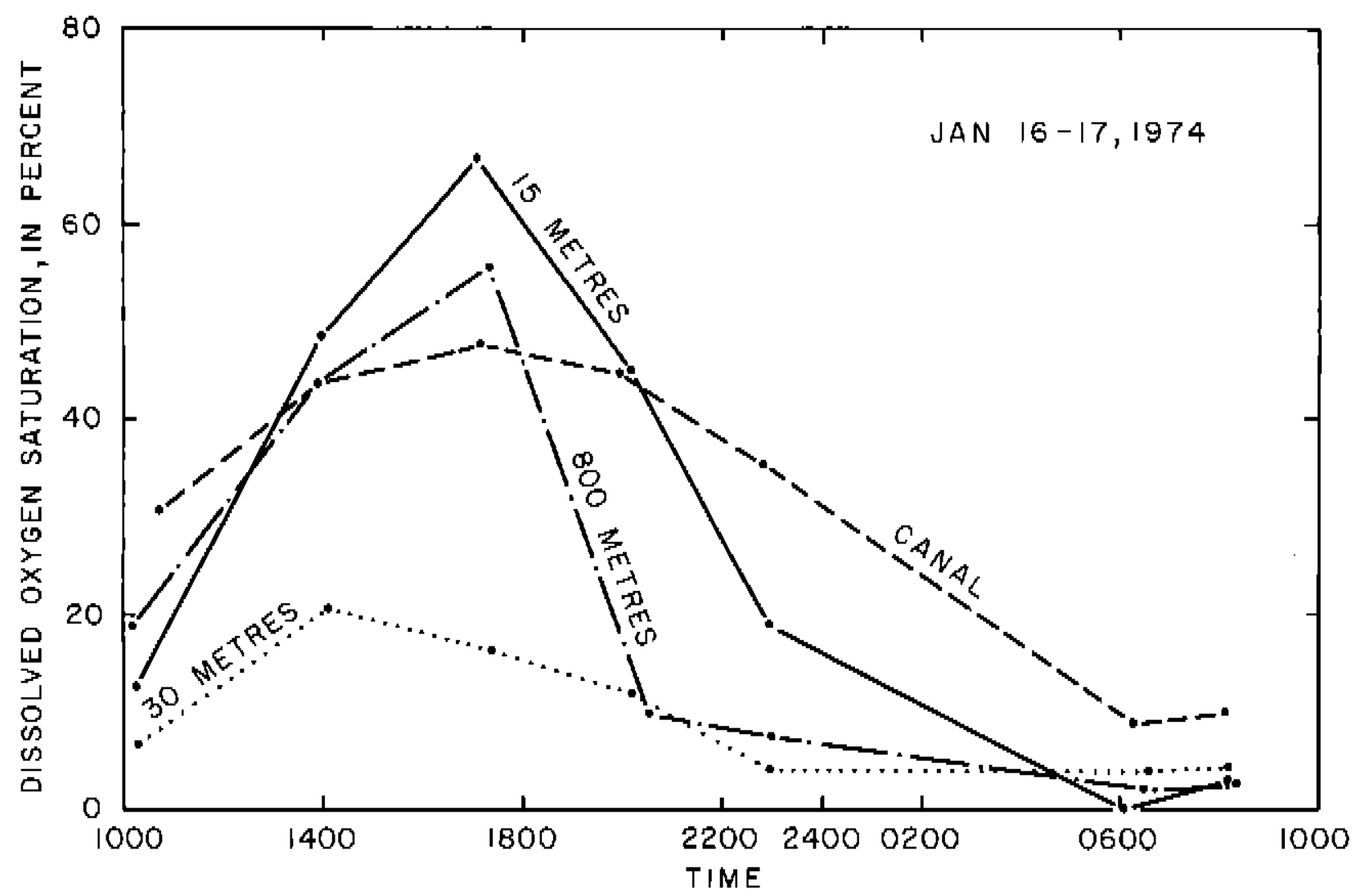

Figure 12,--Dicl changcs in dissolved oxygen in a canal and ils peripheral marghes at the north end of Conservation Arca 2A near 5-10C. Distances are from canal south into marshes of Conservation Area 2A. (For location see figure 3A). 
Data are avallable to document seasonal diel fluctuations of dissolved oxygen at L-28 canal in the western part ol Conservation Area 3A. These daLa indicate that diel liluctuations are varlable from month to month, from season Lo season, and fron year to year during the same month (figs. 1.3 and 14 ). Maximum oxygen saturation, measured guarterly or monthly for 4 years, cxcceded 100 percent 4 of 18 times. Createst oxygen production occurred in spring and was closely related to low water lcvel. Ilighest oxygen concentrations occurred at lowest water leve1, in May 1971. (fig. 14). Dfssolved oxygen fluctuaced less than 50 perceml over 24 hours in most cascs,

\section{Nitrogen and Phosphorus}

Inorganic nutrients In water might be expected to change in concentration during 24-hour periods in response to biological matabolism. They would be removed from the water during the day by phocosynthesis and released to the water at night by respiration. If pholosynthesis exceeded raspiration, a net dccrcase in nutrients would occur in the water.

Data were collected over 24-hour periods for nitrate, nitrite, amnonit, and orthophosphate (or orthophosphate plus acid hydrolyzable phosphorus) at sites near S-5A (January 16-17, 1973 and september 10-1.2, 1973), S-9 (J anuary 16-17, 1973), the Hillsboro Cana1 (January 16-17, 1974), and at L-28 Cama1 (Septomber 10-11, 1973). Some changes in these nutrients were recorded over diel cycles; however, thesc changes are largely attributable to inflow of water of a different chemical character as judicaced by changes in specific conductance. Thus, melabolic changes in concentrations of phosphorus and inorganic nitrogen were not cvident over diel cycles at these sites (Basic Data $B$, C, D).

\section{Chemical Changes with Backpumping}

\section{Pumping Station S-5A}

On september 10, 1973 diel studies were begun near pump station S-5A. Water harl last becn pumpad inco Area 1 on September $7\left(15.0 \mathrm{~m}^{3} / \mathrm{s}\right.$ or $530 \mathrm{f}$. L 3/s). On september 8 and 9 water was pumped from Area 1 into the west Palm Beach Canal $\left(2.7 \mathrm{~m}^{3} / \mathrm{s}\right.$ and $2.5 \mathrm{~m}^{3} / \mathrm{s}$ or $95 \mathrm{IL}^{3} / \mathrm{s}$ and $\left.88 \mathrm{ft}^{3} / \mathrm{s}\right)$. During the dLel study $5.6 \mathrm{~m}^{3} / \mathrm{s}(1.98 \mathrm{fl} / \mathrm{s})$ of water wore pumped from the canal into $\Lambda \mathrm{res} I$ on on the 10 th and $3.4 \mathrm{~m}^{3} / \mathrm{s}\left(120 \mathrm{IL}^{3} / \mathrm{s}\right)$ on the 11 th.

In the West Palm Heach Canal (site I, itg. 4), waler remaincd rolarively stratified during the flrut day of the dicl study. Specilite conductance ncar the bottom was about double that near the surface, By september 11 , however, Lhe water was mixed and specific conductance was relalively uniform with dejth.

The concentration of dissolved oxygen tended to be hLgher at site $\mathrm{l}$, in the West Palm Beach Canal, where it ranged from 32 to 68 percent saturation near the surface, than at the other canal. sites within Area 1 , where it ranged From abouc 10 to 30 percent saturation (sec Fir. 4 for site locations). For comparison, dissolved oxygen at the index site aL L-28 ranged lrom about 35 to 75 porcent saturation near the surface and from about 2.5 to 45 percent saturation near the bottom. 


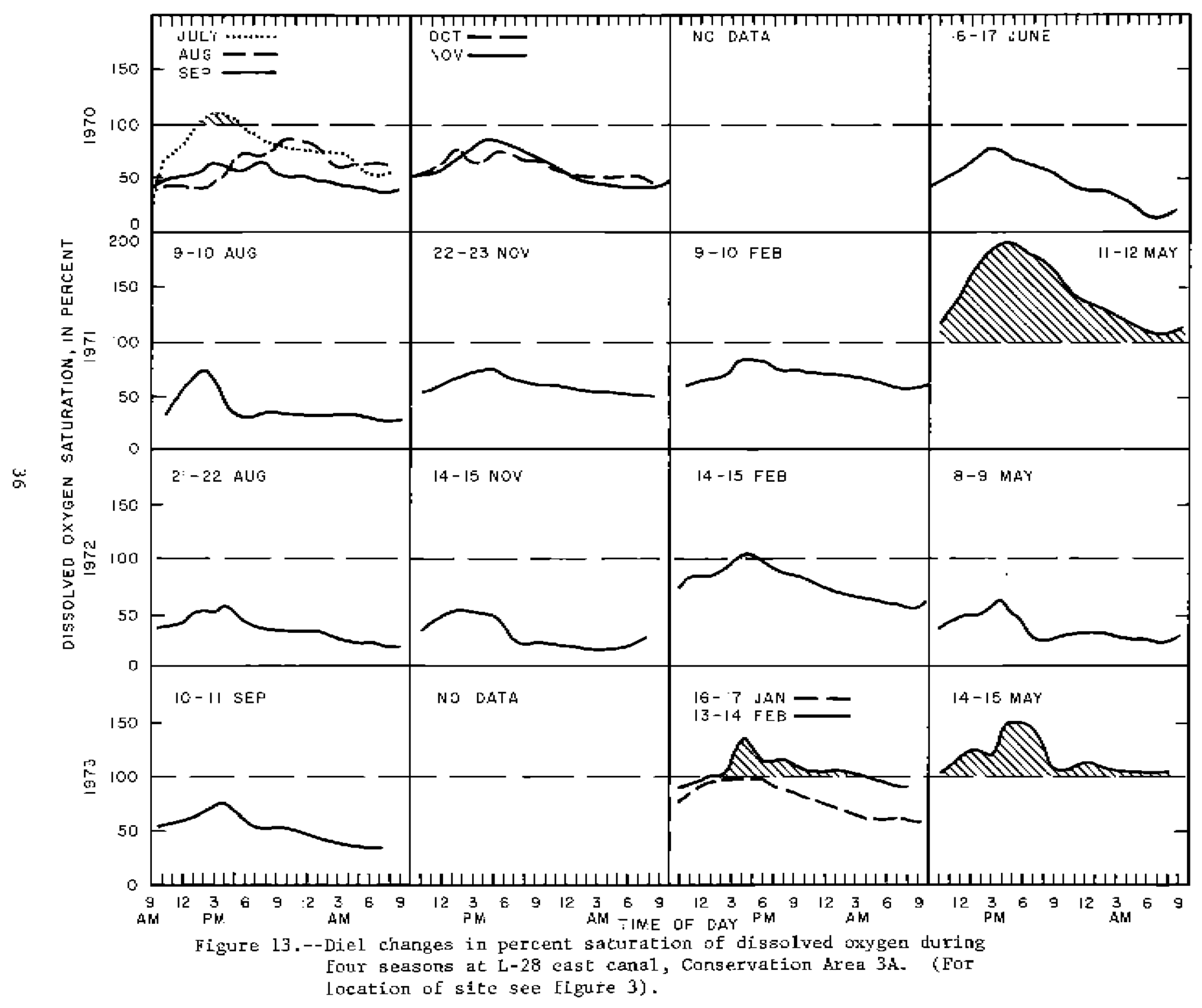




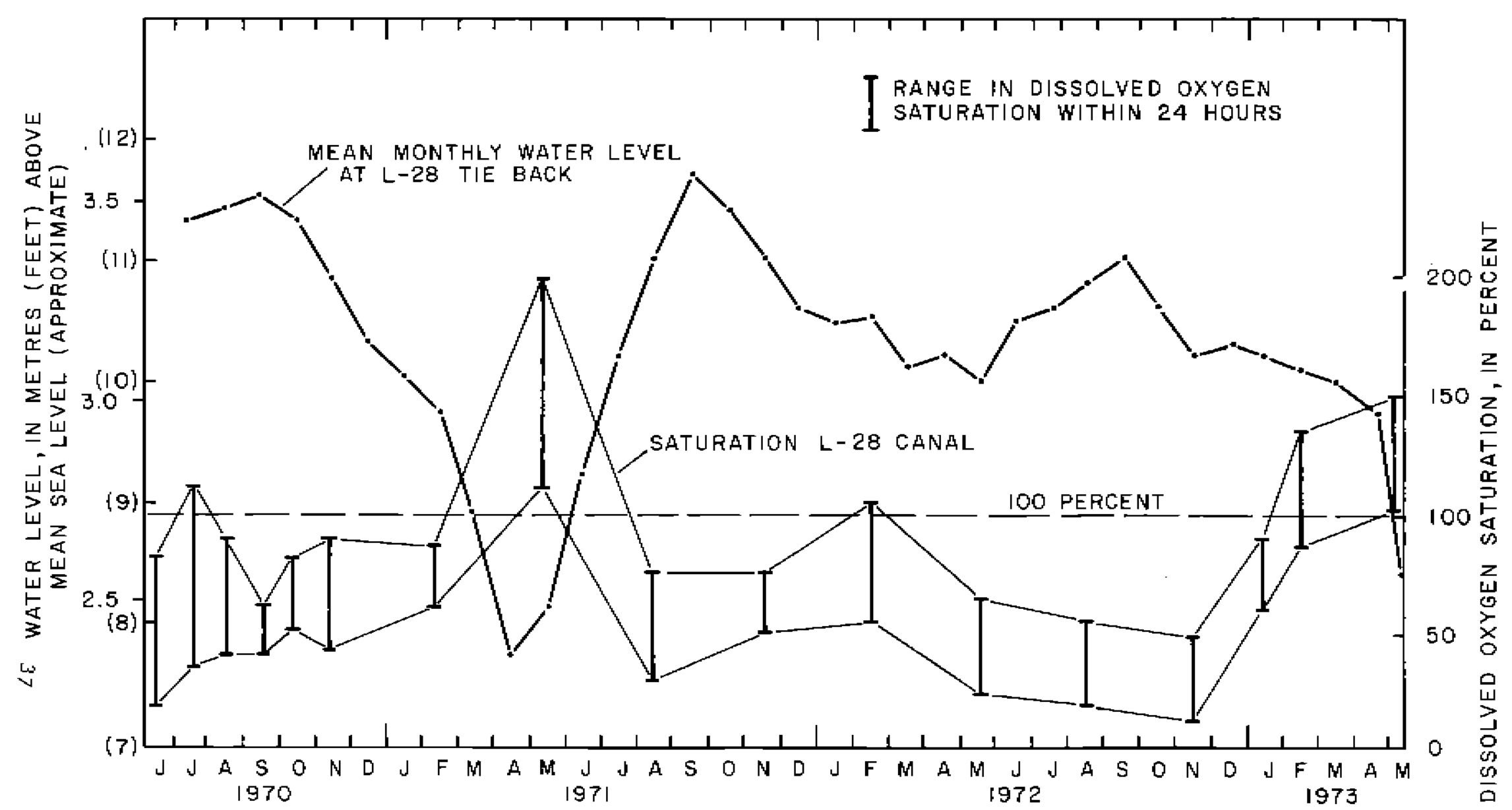

Figure 14.--Seasonal changes in percent saturation of dissolved oxygen at L-28 east canal, 1970-73. (For location of L-28 canal and L-28 tie back see figure $2 \mathrm{~A}$ ). 
Pumping appeared to have little effect on dissolved uxygen in the West I'alm Beach Canal (site 1), but caused a nearly uniform concontration in the Arca I carlal (sile 2) downstrcam of S-5A (Fir. 15). Before pumping, bottom waters at all sites ( 2.4 Lo 3.6 metrcs or 7.9 to 11.8 feel) vere virtually devoid of oxygen; after pumping, dissolved oxygen at ailes within $\Lambda$ rea 1 was only slightly lower at the bottom than at the top. The average dissolved oxygen increased after pumping began, causcd partly by the influx of water from the west Paln Beach Canal which containcd highcr concentrations of oxygen.

Probably the most pronounced effect on water quality after pumping was the sharp rise in the conccntrations of ammonia al sites downstream (table 4 ). At site 2, for cxample, the average concentration on september 10 , 1973 increased from 0.53 to $1.4 \mathrm{mg} / \mathrm{L}$ (NT/3-N). The high concentration of ammonia may result from an appreciable ground water contribution to the Area l camals, from a mixing effect chat relesses ummonia from bottom scdiments, or frow the brcakdown of organic nitrogen to ammonia, Concentrations of ammonia djd not increasc in the West Palm Beach canal with pumping, and remined lcss than half of those in the conservation area canals. This suggests a mixing effect, which facilitates the broakdown of organic nitrogen or which releases anumia from the bottom scdiment, may be tho most important cause of the rise In ammonia concentration. The increase i.n antuonia occurred at least 2 kLlometres downstream on september 10; no increase was detected at 3 kilometres ( 9 ilte 7) throughout the diel study ending at 0725 hours on september 12 .

The sverage concentrations of orthophosphate, nitrite, and nitrate decreased slightly after pumping at most of the sites in the conscrvation arca canals (table 4). The greatest clecreases were at sites 2 , 3, and 4 which were nearest the pump station. Speclfic conductance increased slightly at tho same sites. ThLs suggests that the mixing effect of pumping locally increased the uptake of the orthophosphate, nitrite, and nitrate.

\section{Plimplig Station S-9}

Diel studies were made at s-9 (fig. 5) on January 16-18, 1973. On January 16 no water was backpumped west into Conservation Area $3 \mathrm{~A}$; on the 17 th water was backpumped for aboul 7 hours.

on $\mathrm{January} 17, \quad 52.4 \mathrm{~m}^{3} / \mathrm{s}\left(1.850 \mathrm{ft}^{3} / \mathrm{s}\right)$ of water were backpumped from the South New River Canal westward into Conservation Area 3A. Of that water 27.8 $\mathrm{m}^{3} / \mathrm{s}\left(981 \mathrm{ft}^{3} / \mathrm{s}\right)$ moved northwest in $\mathrm{L}-68$ canal and $24.6 \mathrm{~m}^{3} / \mathrm{s}(868 \mathrm{ft} / \mathrm{s})$ moved southwcst in L-67 canal.

The water in the South Now River Canal at samplfug slle 1 was characterized by hLgh concentrations of anmonia (mostly greater than $0.50 \mathrm{mg} / 1$ as $\mathrm{NI} \cdot 3-\mathrm{N}$ ), and low concentrations of nitrate $(0.01 \mathrm{mg} / \mathrm{I} \mathrm{NO} / \mathrm{N}$ ) and dissolved oxygen (aboul 10 to 15 percent saturation or $1.0 \mathrm{mg} / \mathrm{l}$ ). According to Freiberger (1973) the reason for the high concentration of amonia east of $s-9$ is that most of the canal is in an anaerobje state much of the year due to inflow of ground water during backpuming. Ground water is generajly low in dissolved oxygen; undor anrerobic conditions amonia is the common form of inorganic nitrogen. 


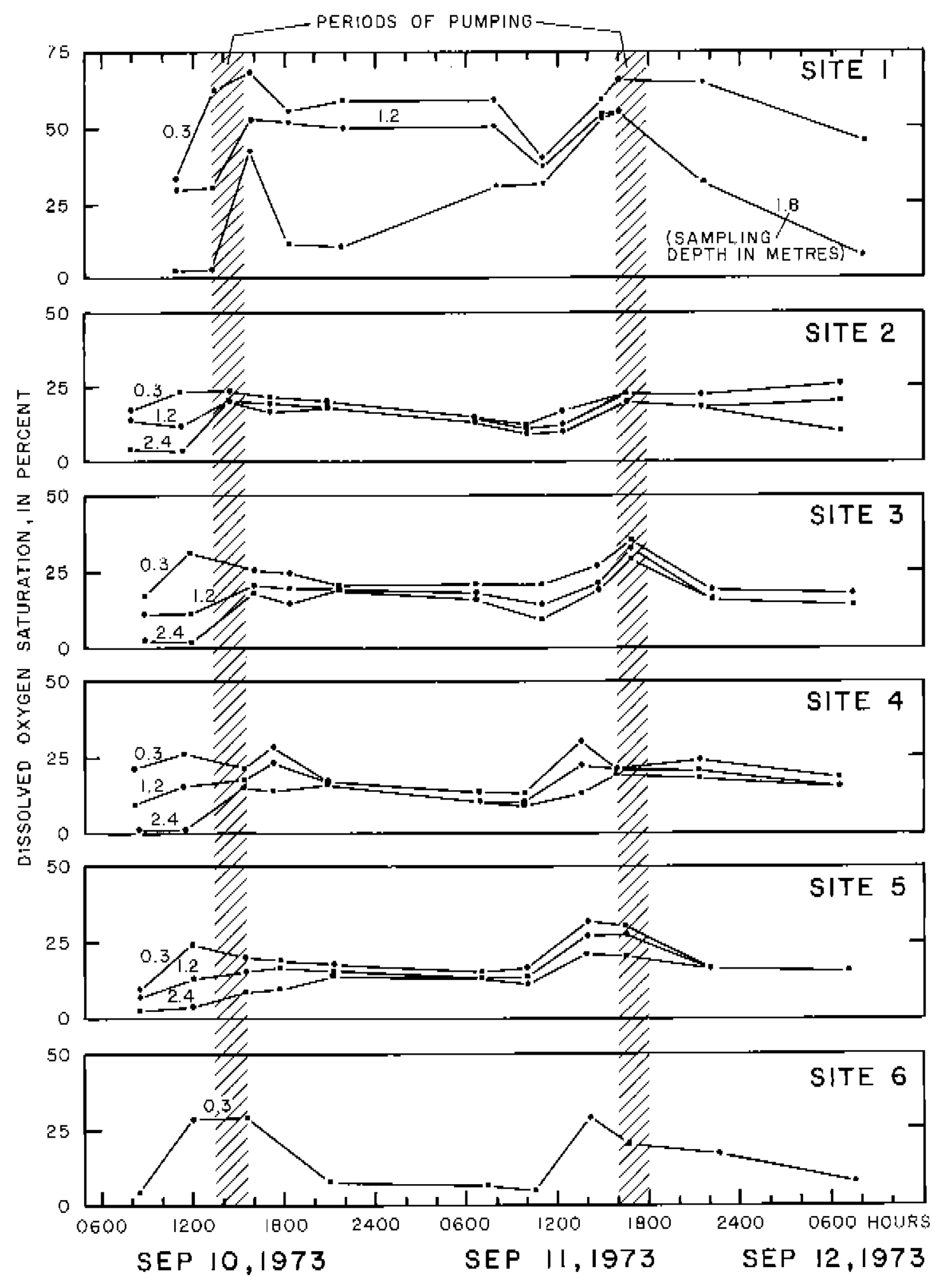

Higure 15.--Dissolved oxygen concentrations in waters arome S-5A in Conservation Area 1, Septenber 10-12, 1973. 
'lable 4.--Average concentrations of nutrienls on September 10,1973 at sampling sites near $s-5 \Lambda$ before pumping and aftex p(rmping (basic Data $\mathrm{E}$ ). (No water was pumped Into Area 1 for 2 days before Seplember 10, 1973. For location of sampling sites sce figure 4. )

Before

After

Samp1Ing site 1 (above $\$-5 \mathrm{~A}$ )

pumping

pumping

Number of gamples (N)

4

4

Specific conductance

780

677

$\mathrm{PO}_{4}$ as $\mathrm{P}$ ( $\left.\mathrm{mg} / 1\right)$

0.03

0.02

$\mathrm{NH} 3$ as $\mathrm{N}$ (mg/1)

0.60

0.54

$\mathrm{NO}_{2}$ as $\mathrm{N}$ (mg/l)

0.04

0.03

$\mathrm{NO}_{3}$ as $\mathrm{N}$ (mg/1)

0.30

0.27

Dissolved oxygen (DO) mg/1

1.5

3.3

Sampling site? (below $S-5 \Lambda$ )

$\mathrm{N}$

Specific Conductance

1101

I2

PO4 as $\mathrm{P}$

.05

1158

$\mathrm{NH} 3$ as $\mathrm{N}$

.53

.03

$\mathrm{NO}_{2}$ as $\mathrm{N}$

.11

1.4

$\mathrm{NO}_{3}$ as $\mathrm{N}$

.41

.09

Do

.8

.30

1.5

\section{Sampling gite 3 (Canal 7)}

$\mathrm{N}$

Speeifie: Conductance

$\mathrm{PO} 4$ as $\mathrm{P}$

NT 3 as $\mathrm{N}$

$\mathrm{NO}_{2}$ as $\mathrm{N}$

$\mathrm{NO}_{3}$ as $\mathrm{N}$

IXO

Sampling sile 4 (Canal 40)

N

Specific Conduclance

$\mathrm{PO}_{4}$ as. $P$

$\mathrm{NH}_{3}$ as $\mathrm{N}$

$\mathrm{NO}_{2}$ as $\mathrm{N}$

$\mathrm{NO}_{3}$ as $\mathrm{N}$

DO

Samplifing sites 5

$\mathrm{N}$

Specific Conduclance

$\mathrm{PO}_{4}$ as $\mathrm{P}$

NIT 3 as $\mathrm{N}$

$\mathrm{NO}_{2}$ as $\mathrm{N}$

$\mathrm{NO}_{3}^{3}$ as N
4

1090

6

.06

.54

.10

.43

1.1

1209

.03

1.3

.08

.30

1.6
4

1090

.04

.43

.08

.31

1.1

4

1030

.04

.39

.06

.23

.9
6

1253

.03

] 3

.08

.31

1.4

6

1048

.05

.55

.08

.29 
Table 4.--Continued - Average concentrations of nutrients on September 10, 1973 at sampling sites near S-5A before pumping and after pumping (Basic Data E) . (No waler was pumped into Area 1 for 2 daya before September 10, 1973, For location of sampling sites see figure 4.)

Before

$\Lambda$ fter

jumping

puimpling

Sampling sile 7

$\mathrm{N}$

2

Specific Conductance

$-$

$\mathrm{PO}_{4}$ as $\mathrm{P}$.

.05

$\mathrm{NI} 3$ as $\mathrm{N}$

.42

$\mathrm{NO}_{2}$ as $\mathrm{N}$

.07

$\mathrm{NO}_{3}$ as $\mathrm{N}$

.21

DO

1.0

4

1005

.04

.38

.06

.20

1,4 
Backpumping from the South New River Canal had a definite effect on three waler quality constituents in Conservation $M r e a 3 \Lambda$. This effect is consistcnt with that reported by Freiberger (1973). Firat, it Increased the concentration of ammonia (fig, 16). For example, at site 2 near the s-9 discharge the average concentration increased from 0.28 to $0.45 \mathrm{mg} / 1$ (table 5). The jucrease extended along L-67 canal at least 5 kilometres ( 3 miles) southwest of $5-9$ some 8 hours after backpumping began (fLg. 17). Second, backpumping decreased the concentration of nitrate at canal stations in the conservation area (flg. 18 and Table 5). Third, it lowered the dissolved oxygen at canal stations (fig. 19 and Table 5). Marsh sites 4 and 8 were not immediately affccted, but dissolved oxygen was lower on the day after pumping than on the day before pumping ( $f j g$. 20). Nitrate and amonia increased slightly at marsh sites 4 and 8 after backpumping began. At marsh site 3 , northwest of $5-9$, nitrogen and phosphorus changed 1ittle with backpumping.

\section{Nitrogen and Phosphorus Loads}

Rainfall and dry fallout (bulk precipitation) contributed 78 percent (5,200 tonnes or 5,720 tons) of the total nitrogen and 90 percont (207 tonnes or 228 tons) of the total phosphorus that entered the conservation areas from .Tuly 1972 to June 1973 (Waller, 1975). The remaining 22 percent of nitrogen and 10 percent of phosphorus entered at 6 pumping stations and by uncontrolled surface-watex Lnflow. Pumping water ince the conservations added 1,300 tonnes ( 1,420 tons) of nitroper and 21 tonnes (23 tons) of phosphorus. Backpumping, which now occurs only at station $S-9$, added 230 tonnes (253 tons) of nitrogen and 1.8 tonnes (2 tons) of phogphorus to Conservation Area 3.

With the construction of additional pumping stations, canal flow to the sea could bc reduced by increased backpumping Into the conservation areas. is estimated that 50 percent of the cotal annual canal runoff in southeast F1orida, which ranges from $28 \mathrm{~m}^{3} / \mathrm{s}\left(1,000 \mathrm{ft}^{3} / \mathrm{s}\right)$ to $190 \mathrm{~m}^{3} / \mathrm{s}\left(6,800 \mathrm{ft}^{3} / \mathrm{s}\right)$ could be backpumped (Howard Klein, written communication, 1975). Assuming an average concentration for tota. nitrogen of $2 \mathrm{mg} / 1$ and For Lotal phosphorus of $0.02 \mathrm{mg} / \mathrm{l}$ (values comparable with those found today at $\mathrm{s}-9$, see tuble 2 ), baskpumping 50 percont of the total anmul canal runofl would add 900 to 5,600 tonnes (990 to 6,160 tons) of nitrogen and 9 to 56 tonnes (10 to 62 tons) of phosphorus. This constitutes about 15 to 100 percent of the nitrogen and 4 to 27 percent of the phosphorus that entered the conservation areas by bulk precipitation in 1972-73. Urbanization or further agricultural development east of the conscrvation areas would likely increase these loads.

\section{BO'TOM SEDLMEN'I CHEMICAT CJLARACTERISTICS}

Bottom sediment in the Everglades is a combination of organic and inorganic constituents. Sediment in marshes is mostly organic-peat, decaying vegetation, and sometimes periphyton. Sedlment in canals contains limestone, sand, and clay in addition to organic cletritus. Composition of the sediment is variablc dependinfr on runoff, flow velocity, and age of the canals.

Nitrogen and phosphoms occux in the bottom sediment in organic and inorganic forms. Nitrogen is mostly organic with small amounts of fnorganic 


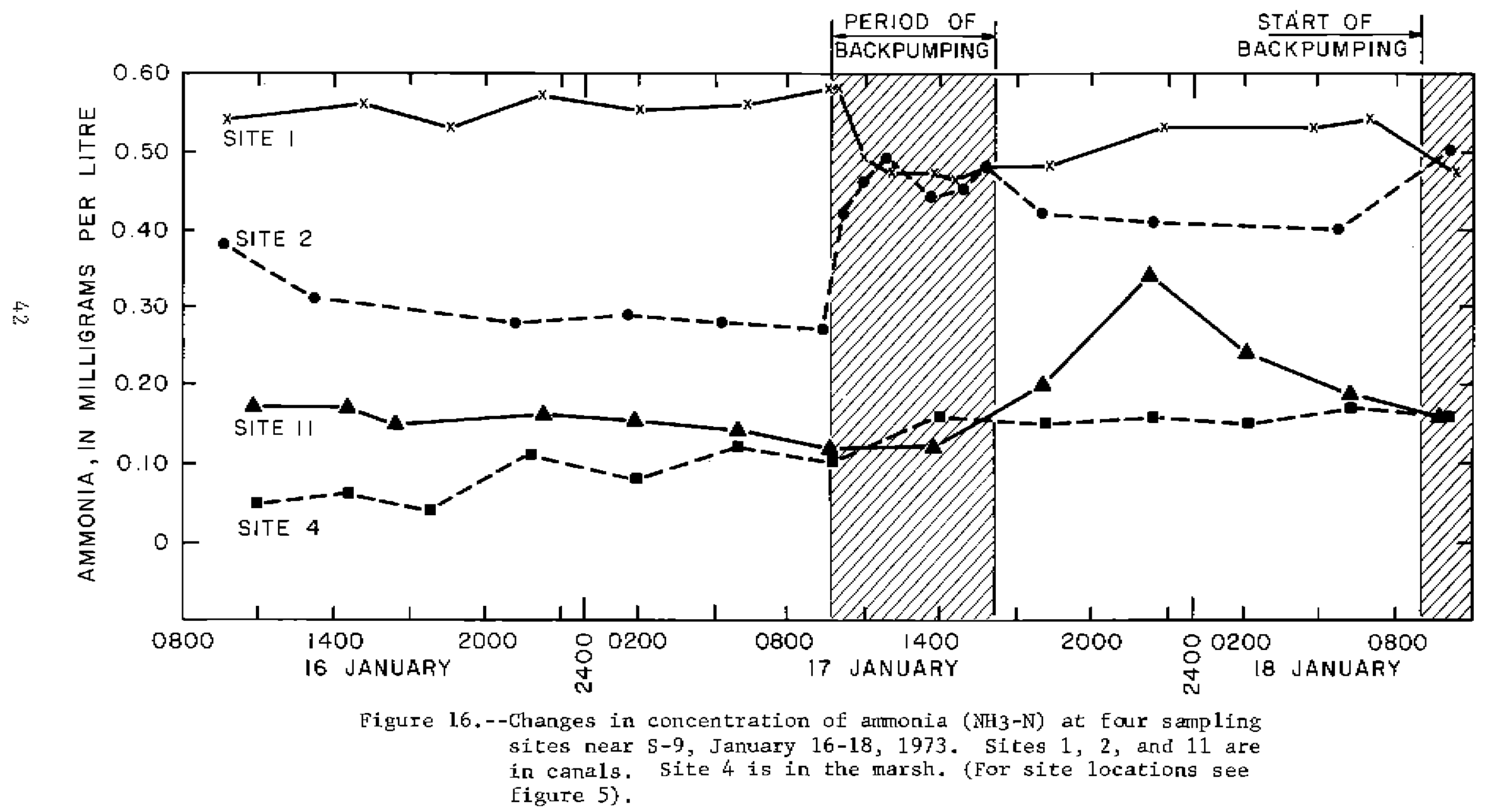


'l'able 5.--Average concentration of mutrlents belore and afler pumping at $\$-9$ on 16-18.January 1973... (Basic Data D). (Selected sites and parameters are graphed in fi.gurcs $\mathbf{1 6 - 2 0}$. Sites are shown on figure 5.)

\section{Site 1 (South New River Canal)}

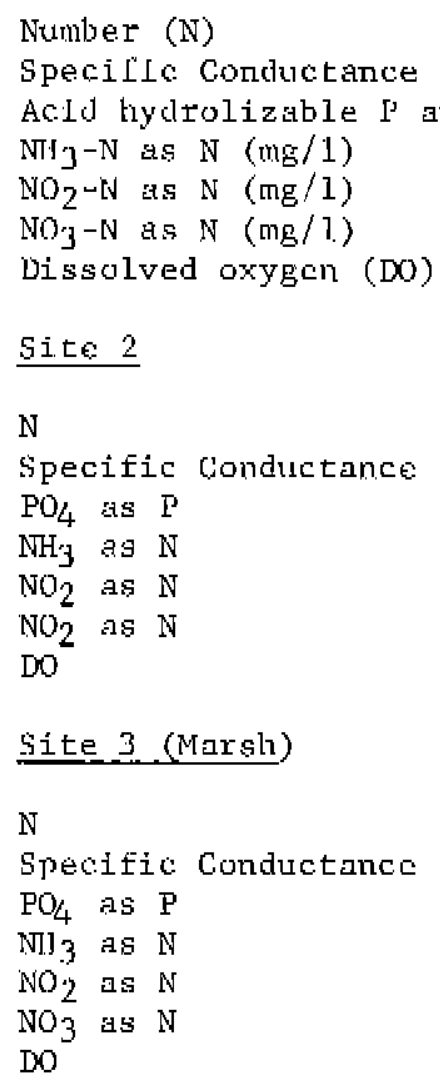

\section{Site 2}

$\mathrm{N}$

Specific Conductance

DO

\section{Site 3 (Marsh)}

$\mathrm{N}$

Specific Conductance

$\mathrm{PO}_{4}$ as $\mathrm{P}$

$\mathrm{NJ}_{3}$ as $\mathrm{N}$

$\mathrm{NO}_{2}$ a $\mathrm{N}$

$\mathrm{NO}_{3}$ a녀 $\mathrm{N}$

IN

\section{Siste 4 (Marsh)}

\section{$\mathrm{N}$}

Specific Conductance

$\mathrm{PO}_{4}$ as $\mathrm{P}$

$\mathrm{NH}_{3}$ as $\mathrm{N}$

$\mathrm{NO}_{2}$ as $\mathrm{N}$

$\mathrm{NO}_{3}$ as $\mathrm{N}$

DO

Site 5 (Canal North)

$\mathrm{N}$

Specitic Conductance

$\mathrm{PO}_{4}$ as $\mathrm{P}$

$\mathrm{NH}_{3}$ 처도 $\mathrm{N}$

$\mathrm{NO}_{2}$ घs $\mathrm{N}$

$\mathrm{NO}_{3}^{2}$ as $\mathrm{N}$ 
Table 5.--Continued - Average concentration of nutrients before and after pumpinc at $\mathrm{S}-9$ on 16-18 January 1973. (Rasic Data D). (Selected sites and parrameters are graphed in figures 16-20. Sites are showt on IIgure 5 .

Before pumping

(0900 to 0950$)$
Dniring and

after pumping

\section{Site 6}

$\mathrm{N}$

Spccific Conductance

$\mathrm{PO} 4$ as $\mathrm{P}$

$\mathrm{NH} 3$ as $\mathrm{N}$

NO2 as $\mathrm{N}$

NO3 as N

DO

\section{Site 7}

$\mathrm{N}$

Specific Conductance $\mathrm{PO} 4$ as $\mathrm{P}$

$\mathrm{NH} 3 a s \mathrm{~N}$

$\mathrm{NO}_{2}$ as $\mathrm{N}$

NO3 as $\mathrm{N}$

DO

\section{Site 8 (Marsh)}

\section{$\mathrm{N}$}

Specific Conductance

PO4 as $\mathrm{P}$

$\mathrm{NH} 3$ as $\mathrm{N}$

NO2 2 as $\mathrm{N}$

$\mathrm{NO}_{3}$ as $\mathrm{N}$

DO

Site 9

$\mathrm{N}$

Specific Conductance

$\mathrm{PO} 4$ as $\mathrm{P}$

$\mathrm{NH} 3$ as $\mathrm{N}$

$\mathrm{NO}_{2}$ as $\mathrm{N}$

$\mathrm{NO}_{3}$ as $\mathrm{N}$

DO

\section{Site 10}

$\mathrm{N}$

Specific Conductance $\mathrm{PO}_{4}$ as $\mathrm{P}$

$\mathrm{NH}_{3}$ as $\mathrm{N}$

No 2 as $N$

$\mathrm{NO}_{3}^{2}$ as $\mathrm{N}$

$\mathrm{DO}_{3}$ as $\mathrm{N}$

\section{7}

878

.00

.11

.01

.08

6.9

7

797

.00

.24

.02

.14

3.9

\section{7}

785

.00

.04

.00

.03

4.1

\section{6}

873

.00

.12

.00

.07

6.5
6

768

.00

.41

.00

.04

1.8

6

813

.00

.05

.00

.05

3.7
7

846

.00

.18

.01

.12

5.2

6-7

867

.00

.14

.00

6.0

$43 a$
5-6

795

.00

.33

.00

.05

3.6 
Table 5.--Continued - Average concentration of nutrients beforc and after pumping at $5-9$ on 16-18.January 1973. (Basic Data D). (Selected sites and parameters are graphed in figures 16-20. Sites are shown orl fi.gure 5 .

Before pumping

$(0900$ to 0950$)$
During and atler pumping

SiLe 11

$\mathrm{N}$

Specifle Conductance

$\mathrm{I}^{3} \mathrm{O}_{4}$ as $\mathrm{P}$

$\mathrm{NH}_{3}$ as $\mathrm{N}$

$\mathrm{NO}_{2}$ as $\mathrm{N}$

$\mathrm{NO}_{3}$ as $\mathrm{N}$

DO
7

861 .

.00

.15

.00

.13

9.4
6

843

.00

.21

.00

.07

4.3 


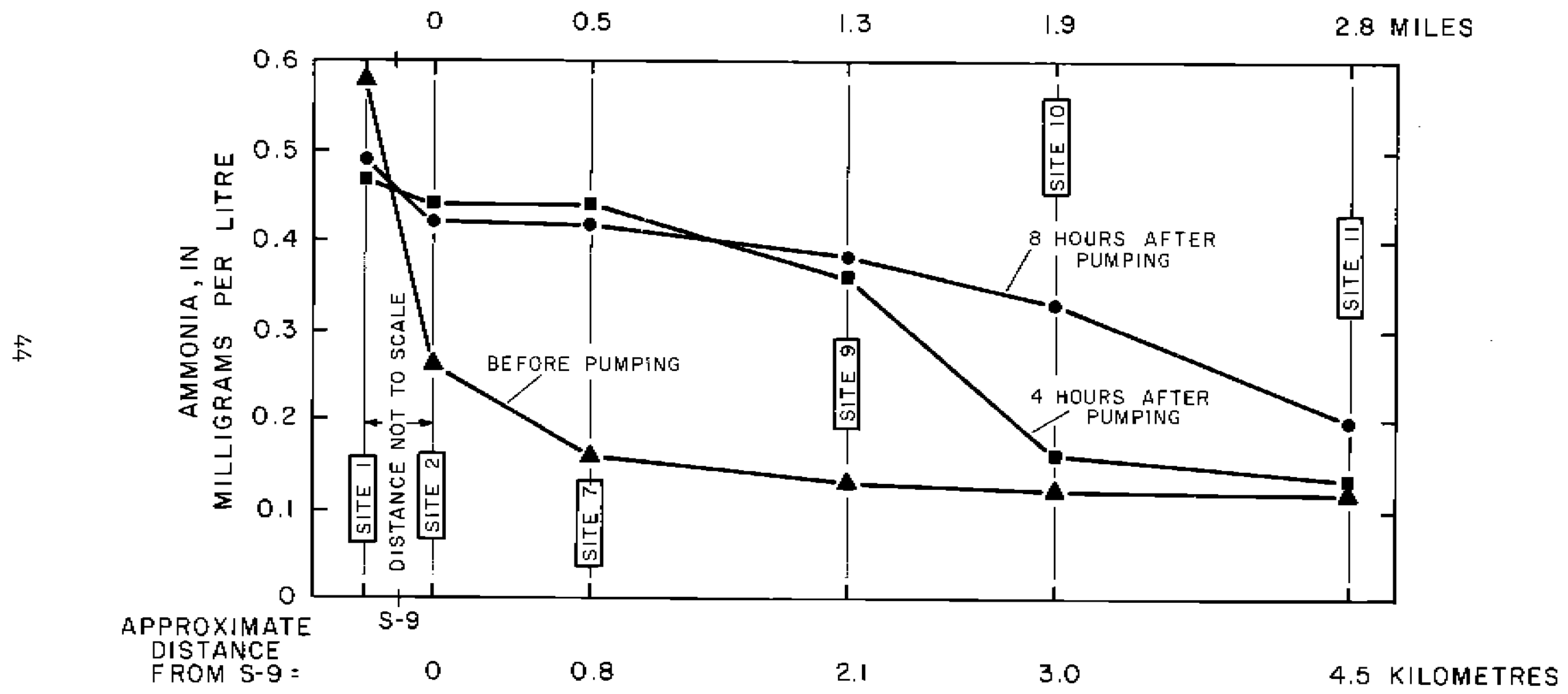

Figure 17.--Changes in concentration of ammonia ( $\mathrm{NH}_{3}-\mathrm{N}$ ) at six sampling sites near S-9, January 16-17, 1973. Concentrations are those before backpumping began, four hours after backpumping began, and eight hours after backpumping. (For site locations see figure 5). 


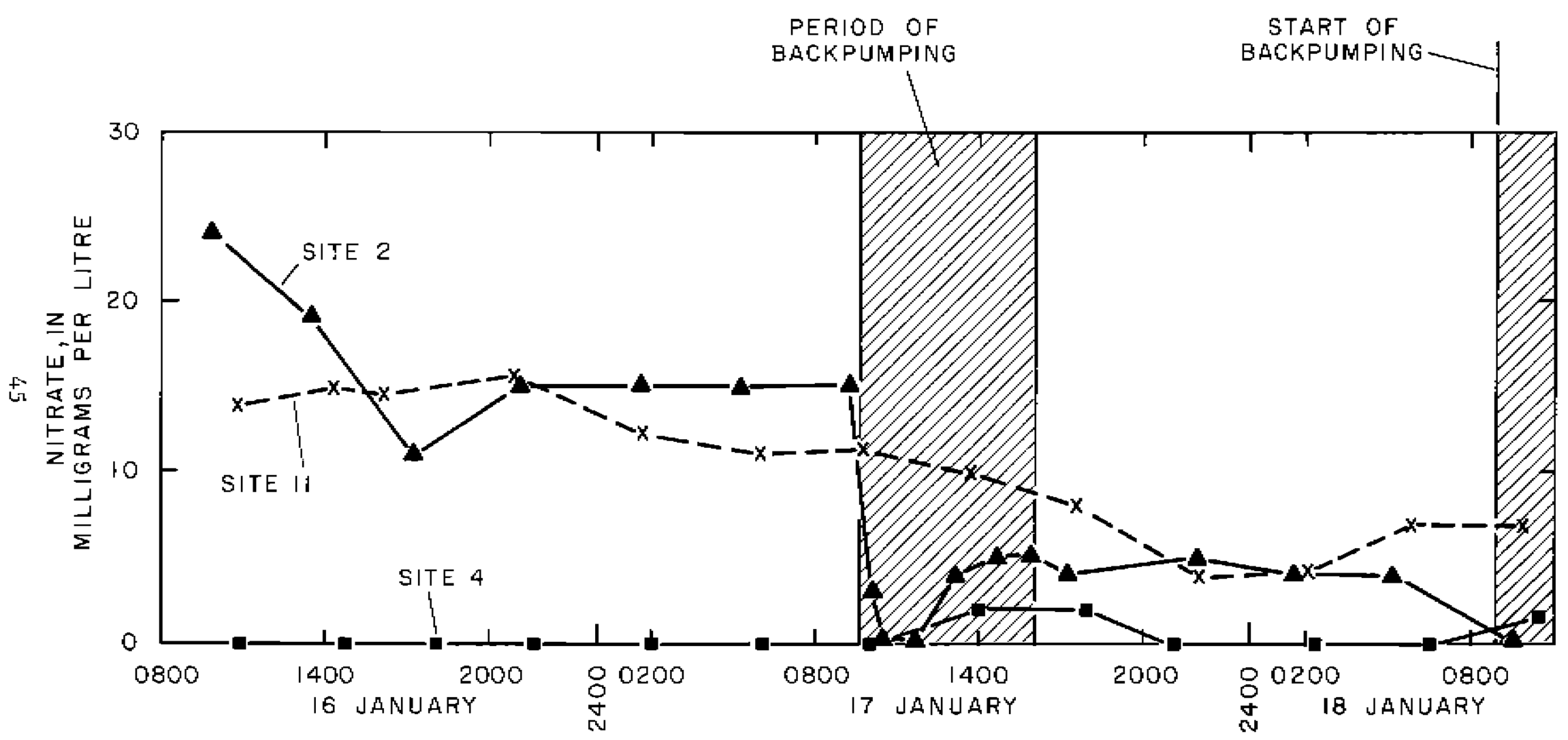

Figure 18.--Changes in concentration of nitrate ( $\mathrm{HO}_{3}-\mathrm{N}$ ) at three sampling sites near S-9, January $16-18$, 1973. Sites 2 and 11 are in canals; site 4 is in the narsh. (For locations see figure 5). 


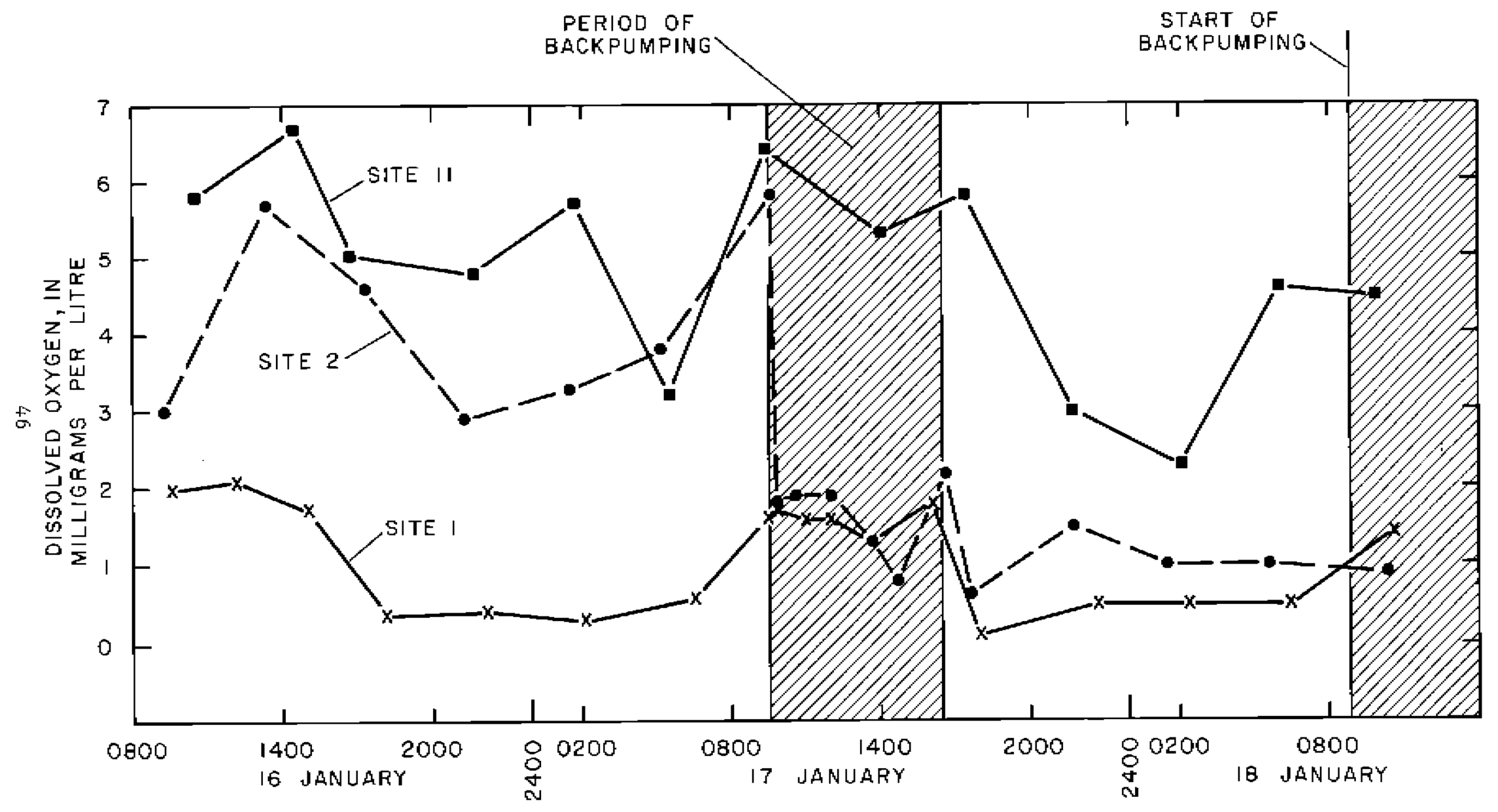

Figure 19.--Changes in dissolved oxygen at three sampling sites near 5-9, January 16-18, 1973. (For site locations see figure 5). 


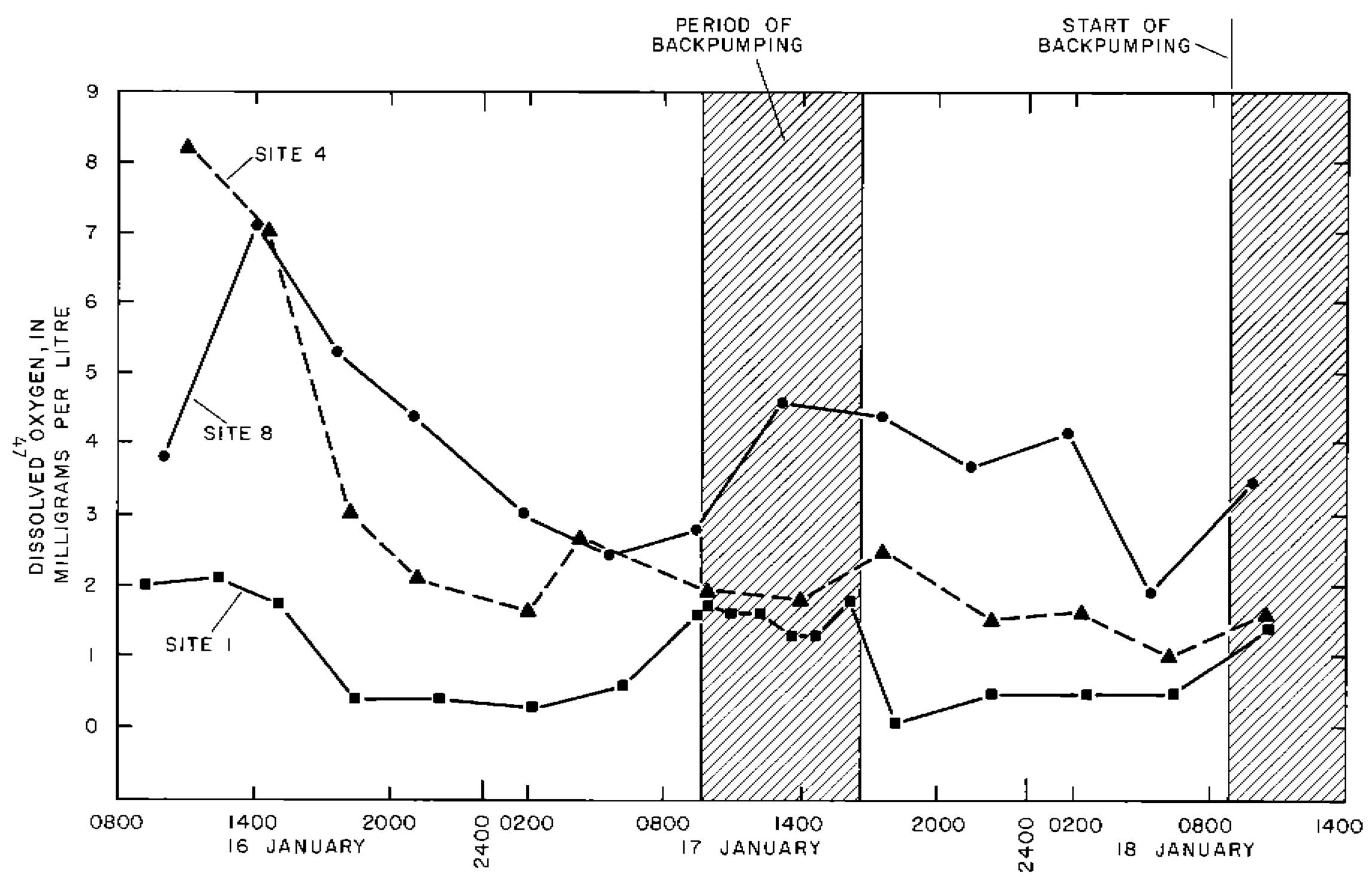

Figure 20.--Changes in dissolved oxygen at three sampling sites near s-9, January 16-18, 1973. (For site locations see figure 5). 
antonia. Phosphorus occurs elther in organic form, derived from plants and animals, or inorganic lom, derived from clays and minerals.

Nitrogen in bottom material is usually unavailable to the ovcrlying water, Under anaerobic conditions, however, ammonla may be released From the sediments. Also, ammonia may be released when the sediment is aritated, when urea is excreted trom benthic organisms, or when organic cells break dowt. The bottom materials act as a nitrogen gink by accumulating organics that have settled, by adsorbing ammonia onto clays, metal oxicles, hydroxides, and organic colloids, and by the process of dchitrification under anaerobic conditions.

Phosphorus in bottom sediments may be derived from many sources. The organic fraction, usually proteins or enzymes, may come from bottom organisms or from organisms lhat sink from the water above. 'lhe inorganle fraction may come from the breakdown of organic matarial or from mLnerals ju. runoti and rajilal. The common inorganic form, phosplate, is often sorbed on organic colloids, associated with carbonates or preclpitated by aluminum, iron, or manganese. Phosphate minerals release little voluble phosphate to the water.

Phosphorus uptake and release from bottom materials are controllcd minly by $\mathrm{pH}$ and redox potential. at the water-sediment interface, by concentrations of oxygen, calcium, iron, aluminum, and mangancse, and by sediment mixing and agilation. Under anacrobic conditions, which result in low redox potencial, phosphorus is released from the sedinent. Under aerobic condiLions, however, i.t is bound in the sediments with iron, aluminum, and manganese hydroxides and oxides. The release of phosphorus from sediments Is also facilitatcd by high (greater than 7) or low (less thrir 5) $\mathrm{pH}$. High concentrations of calcium will scavenge Imorganic phosphorus from the water column by forming precipitates.

Chemical analyses of bottom sedimencs lrom the Fverglades marshes and canals are shown j.n Table 6 . The average concentration of orgatic material in the botrom sediment at 11 long-term slies ranged from 2.5 to 87 percenl. The average marsh concentrations ranfed from 62 to 87 percent, ancl che average in canals from 2.5 to 49 percent. Because the amount of urganic matenrial determines to a large degree the coneentrations ol nitrogen and phosphorus as well as melals, the average concentration of these clements also varied widely in the sediment. For exampla, the averape nitrogen concontracion ranged l'xom 1.9 to $4.6 \mathrm{~g} / \mathrm{kg}$, and phosphorus ranged from 7.5 to $640 \mathrm{mg} / \mathrm{kg}$ -

To compare elemental composition of scdiment samples with dillerent. amounts of organic: matter, it is necessary to normalize the samples. Thj.s can be done by calculating the amount of nitrogen and phosphorus prescnt in. the sediment for each $100 \mathrm{gram}$ of organic carbon. For exarple, $i f$ onc semple has twice as much organic mutter as another, one would cxpect, under comparable envixomental conditions, twice as moh phosphorus, nitrogen, und metals in the organically rich sample ats in the orranically poor sample. once normalized, differences in clemental concentrations may be attributed to lactors other than organic content. For example, sodiments may be enriched in a particular element because ol contamination from an oulside source. 


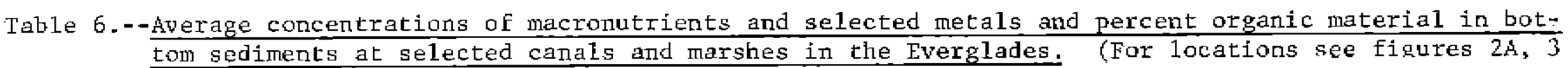
and 5B.) $\begin{array}{lccc}\text { Organic } & \text { Total } & \text { Total } & \text { Percent } \\ \text { Garbon } & \text { Nitrogen } & \text { Phosphorus } & \text { Organic }\end{array}$

$\begin{array}{rrr}50,000 & 3,700 & 125 \\ 257,000 & 14,000 & 83 \\ 90,000 & 10,000 & 87 \\ 8,300 & 1,900 & 490 \\ 6,500 & 4,400 & 640\end{array}$

$\begin{array}{rr}15.9 & 3,850 \\ 49.1 & 3,250 \\ 23.6 & 5,650 \\ 2.5 & 2,440 \\ 3.1 & 652\end{array}$

47

67

97

$\mathrm{S}-7$

$\mathrm{s}-8$

$5-9$

640

Average

Non Agricultural Canals

$$
\begin{aligned}
& S-11 C \\
& L-67 A \\
& L-28 \text { East }
\end{aligned}
$$

94,000

67,000

82,000

5,500

6,600

15,000
28.3

16.0

22.3
4,300

5,170
7,700

131

137

110
13

21

10

39

69

46

Average

Marshes

$$
\begin{aligned}
& 1-15 \\
& 2-17 \\
& 3-28
\end{aligned}
$$

$$
\begin{array}{ll}
420,000 & 38,000 \\
282,000 & 23,000 \\
366,000 & 46,000
\end{array}
$$

167

235

250

$\begin{array}{rrr}86.6 & 2,370 & 98 \\ 67.9 & 1,310 & 97 \\ 62.4 & 6,620 & 126\end{array}$

35

28

128

12

59

Average 
When the chemical daca fron Table 6 were normalized to organic carbon, the average concentrations of nitrogen, phosphorus, iron, copper, and lead were generally highest in the canals near jumping stalions, somewhat lower in the canals remote from pumping, and lowest in the interior marshes (table 7). Average concentrations for a specific element in the marsh were relatively uniform, but concentrations in the cands varied greatly. ThIs suggests that the elemental sedinent composition in each canal may be controlled by complex factors not accounted for by the simple categorization of canals into those near pumping stations and those remote from pumplng stations. -

The chemical composition of the sediment in canals may be dynamis, compared with that of the sediment in marshes, because the sediment in canals Is exposed to relatively rapid water flow, turbulence, and resuspersion, particularly near the pumping stations, Resuspension may release soluble nitrogen and phosphorus burled in the sediment and also increase thc exposure of sediment surlace area to biological and chemical activity.

A synoptic sampling in the peripheral canals and adjacent marshes of Conservation Arca I was made to detemine the nitrogen and phosphorus concentrations in scdiments. (see Figure 5A for site locations). The analyses of organic carbon, nitrogen, phosphorus and 5 trace metals are glven in Table 8.

There was considerable variation in elemental composition among the samples lrom cands and also among those from the marsh. In genera1, however, the average concentrations of carbon, nitrogen, and notmalized phosphorus differed between these environments. The average organic carbon was about twice as high in the marshes, $307 \mathrm{~g} / \mathrm{kg}$, as It was In the canals, 149 $\mathrm{g} / \mathrm{kg}$. Nitrogen concentrations were about three times higher in marsh sediments than in the canal sediments, avcraging $27 \mathrm{~g} / \mathrm{kg}$ and $10 \mathrm{~g} / \mathrm{kg}$ respectively. However, normalized nitrogen concentrations were about the same in the two environments. Average phosphorus concentrations werc about the same in the two environments (183 and $187 \mathrm{mg} / \mathrm{kg}$ ). However, when the phosphorus concentrations werc normalized to account for differences in organic matter, phosphorus was higher in thc canal sediments, $200 \mathrm{mg} / \mathrm{kg}$, whan in the marsh sediments, $62 \mathrm{mg} / \mathrm{kg}$ (table 9).

Ratios of curbon to nitrogen to phosphorus (C:N:P), based on the average values for canal and marsh sediments given in Table 8, further illustrate the phosphorus enrichment in canal sedjments with respect to carbon and nitrogen. The C:N:P ratio in cancl sediments was 810:55:1 as compared with $1610: 145: 1$ i.n the marsh sediments, indicating phosphorus in canal sediments is enriched by a Eactor of 2 to 2,6 .

The concentration of iron, manganesc, copper, lead, and mercury in the bottom sediments varied widely and no areal pattern was evident (Tablo 8). There were differences, however, between the average concentrations in cands and marghes. When normalized to the amount of organic carbon in the sediment, the 15 canal samples were slightly enriched, on the average, in mangancse, irotl, copper, and lead compared with the 7 marsh samples.

At sciected sites within the Fverglades, aquatic marsh plants and bottom sedinents were collected and anclyzed for nitrogen, phosphorus, and 


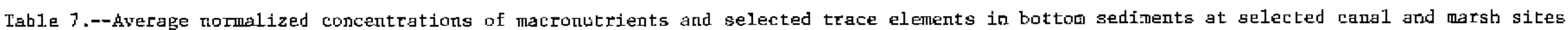

in the Everglades. Averages of 4 samples collected quarterly, October 1972, Aprtl and occober 1973 and apri1 1974. Jata are noma1ized to 100 grans per kilogram organic carbon.)
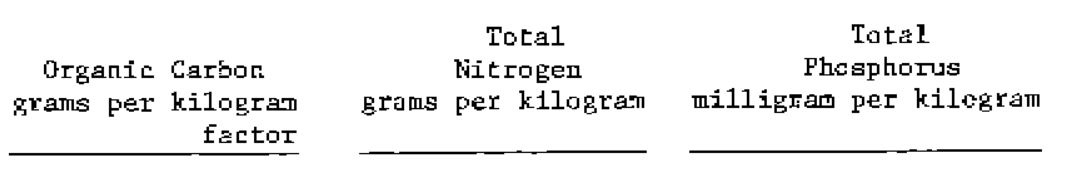

Agrtcultura1 Canals

rear pumpirs stations

$\begin{array}{lll}5-5 A & 100 & 0.2 \\ \text { S-6 } & 200 & .4 \\ \text { S-7 } & 100 & 1.1 \\ \text { S-8 } & 100 & 12 \\ \text { S-9 } & 100 & 15\end{array}$

duerage

Non-Agricultural

Canals

average

Marsbes

Average
S- 9

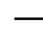

(n)

7.4
5.6
11.0
22.8
66

66

$22-6$

5.8
9.9
18.0

18.0

$\square 1.2$

0.0

8.0

12.4

9.8
Iron Manganese Copper
microgram per prat

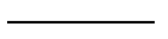

$\begin{array}{rr}230 & 6,700 \\ 33 & 1,300 \\ 96 & 6,215 \\ 5,880 & 29,280 \\ 9,600 & 9,780 \\ 1,440 & 9,094 \\ 191 & 4,558 \\ 11 & 7,755 \\ 132 & 9,240 \\ 111 & 7,194 \\ 40 & 589 \\ 82 & 486 \\ 68 & 1,787 \\ 63 & 954\end{array}$

94
27
107
192
165
117
139
206
116
154
23
34
34
30

70
11
141
144
885
250
41
104
55
66
7
7
13
9


Table 8.--Chemical analyses of boltom sediments collected in Conservation $\Lambda$ rea 1 in February 1974. (Location of sampling sites shown on figure 5A.)

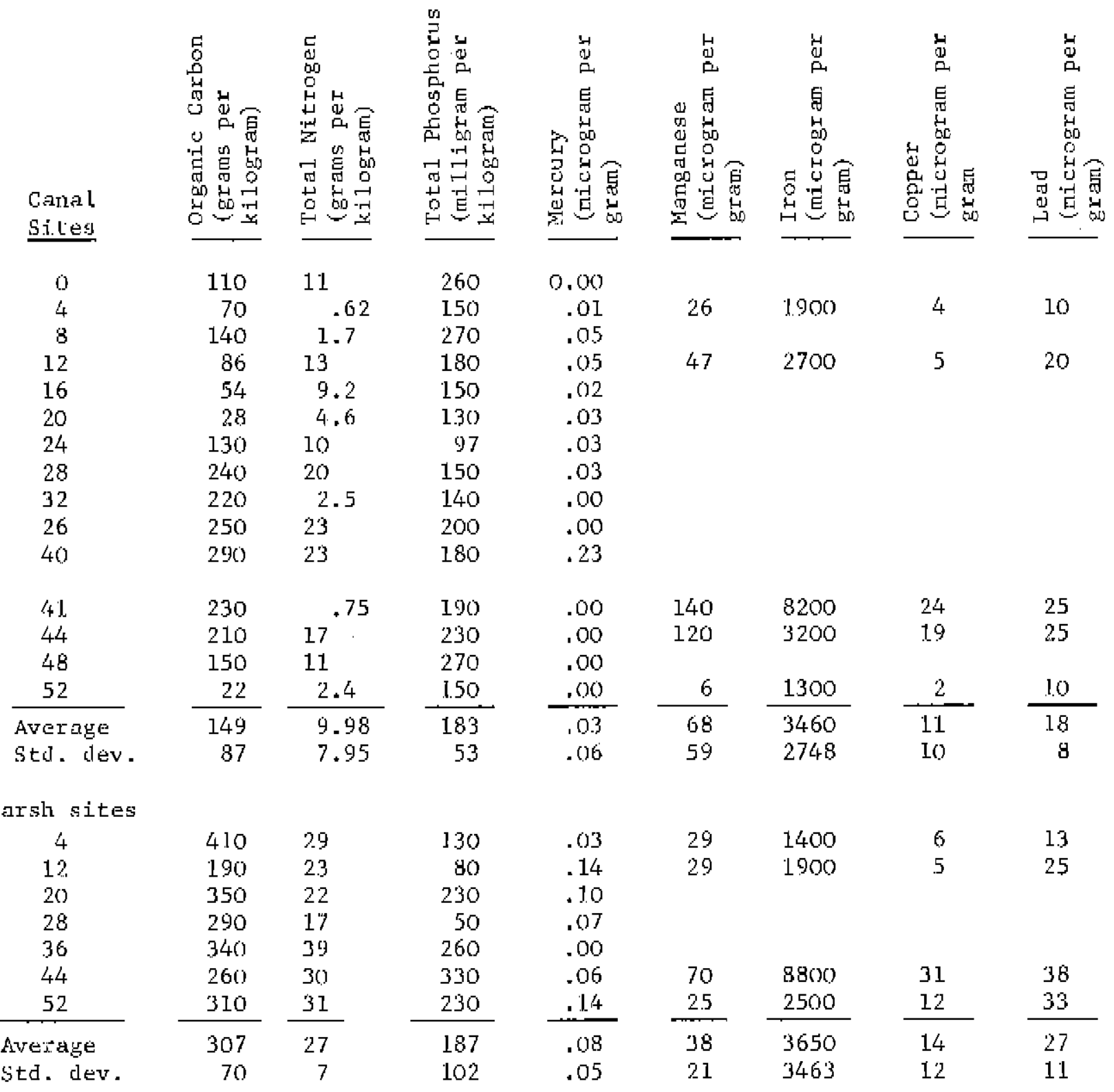


Table 9.--Concentrations of nitrogen and phosphorus In bottom sediments normalized to 100 grams per kilogram organic carbon, February 1974. (Locations shown on figure 5A) .

Canal sites

0

4

8

1,2

16

20

24

28

32

36

40

41

44

48

52

Average

std. dev.

Marsh sites

4

1.2

20

28

36

4 .

52

Average

std. dev.

\begin{tabular}{cc}
$N$ & P \\
\hline 10. & .236 \\
.89 & .215 \\
1.2 & .193 \\
15. & .209 \\
17. & .278 \\
16. & .464 \\
7.7 & .075 \\
8.3 & .063 \\
1.1 & .064 \\
9.2 & .080 \\
7.9 & .062 \\
.33 & .083 \\
8.1 & .110 \\
7.3 & .180 \\
11. & .682 \\
\hline 8.07 & .200 \\
5.43 & .173
\end{tabular}

7.1

12.1

6.3

5.9

1.1. 5

$1,1,5$

10.0

9.20

2.69
.032

.042

.066

.017

.076

.127

.074
.062

.036 
carbon content. The concentration of nitrogen in bottom gediment was about 1,000 times greater than the concentration in the plants, and the concentration of phosphorus in the sedjment was more thin 100 times greater than in aquatic plants (fig. 21). The carbon concentration of both the plants and betliments was simllar indicating the organlc origin of the sediments.

The chemical composition of the bottom sediments within the Everglacles indicate that a variety of factors are controlling the nitrogen and phosphom rus content of these sediments. In general, the sediments are a sink for nitrogen and phosphorus. Walter (1975) estimated chat 74 percent of the total nitrogen and 96 percent of the total phosphorus that enter the conservation areas were retalned.

Under anaerobic conditions or when sediments atre resuspended due to flow and turbulence, bottom sediments may also be a source of nitrogen and phosphorus to the water. For example, the increased concentration of ammonia nitrogen, in the canal waters near S-5A during pumping is probably due, in part, to the release of ammonia from bottom sediments due to mixing and resuspension of these scdiments.

\section{CIIARACI'ERISTICS OF VEGETATION IN THE EVERGLADES}

MARSH AND IN CANALS NEAR PUMPING STATIONS

\section{Introduction}

Most of the Everglades is saw grass marsh interspcrsed with sloughs, wet prairies, and tree islands. Saw grass Is the domlnant plant; it comprises about 65 to 70 percent of the total vegetation cover (Loveless, 1959).

Changes in Everglades vogetative communities may be attributed lo in number of causes - some related to man and some not. Under ideal conditions, vegetation undergoes orderly, successional changes. One community replaces another until a relatively stable situacion is reached in which the final community is in equilibrium wLth its climatic enviroment and is capable of selfperpetuation as long as the climate docs not change radically. 'lhe scable community is called climax; previous oncs are sub-climax. Fach community in this successional change has i.ts own specics, organi\%ation, and conditions. Envirommental factors other than climate ma control and maintain subclimax communities; saw grass marsh, for example, is majntained by pcriodlc scasonal fires. Li.ghtring has always caused some wildfires, particularly during the summer when thunderstorms are common. Wildires during the rainy season are usually less severe than fires during the winter dry scason. Fires durling the dry season are often man-caused.

The northern tverglades has been mostly drained for faming so that little natural vegetation remains except in Conscrvation Arca 1 (Loxalnatche National Wildiffe Refuge). In the southern kverglades two other comservation areas and Everglades National lark contain most of what is left of the natural vegctation. The vagctation within the conservation areas and the Tverglados Natlonal park, 


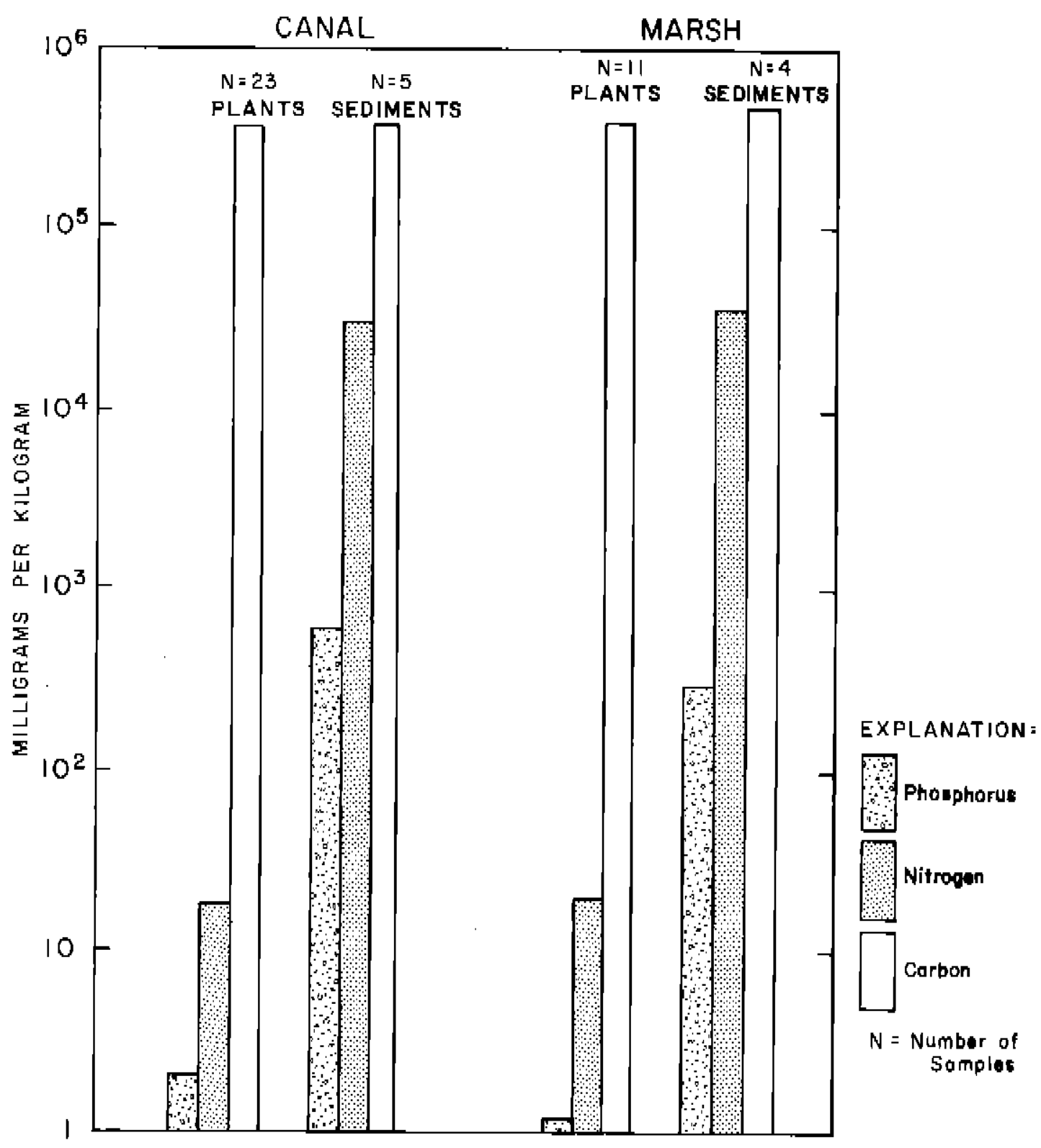

Figure 21.--Carbon, nitrogen, and phosphorus concentrations of aquatic plants and bottom sediments collected in the Everglades, fn Jamuary 1973. (For locations see figures 3 and 5B). 
however, has also been subjected to man-caused enviromental changes. Water impoundment, for example, has altcred hydropexiods and affected plant communitics (Alexander and Crook, 1974; Hagenbuck and others, 1974). Canals have not only clewatered land but have cxeatcd new environments favorable to submerged and floating aquatic plants. Draining and chanclization have cncouraged the sprosd of cxotic plant species some of which are becoming dominants in parts of the tverglades.

In addition to changes in water inundation, vegetaclve communities may be affected by changes in water quality. Incroased injut of nutrients into lakes, for cxample, ofter accolcrates the process of eutrophication. Steward and Ornes (1974a, 1974b) found that siw grass has a low nutrient requirement and probably a limited capacity for removing nutrients from water. onnes and stcward (1974a) also found that enrichment of a saw grass comminity with phosphorus and potassium resulted in phytoplankton blooms, dynamic shlits in phy toplankton gencra, and the disappcarance of aquatic macrophytes chara sp and Utricularia sp. Gleason and Spackman (1974) reported that periphyton composition and biomsss in Area 1 changed in relation to a chemical gradient from perimeter canals into the interior marshes. calcareous, blue green algae of high biomass dominated the periphyton near the perimeter canals where concentration of dissolved solids was high as a regult of agricultural runoff and ground water inllux. This flora changed to a rreen, non-calcareous algal, poriphyton of lower bimass in the incerlor of Area 1 .

\section{Survey and Sampling}

Water of relutively poor quality has been pumped into the Everglades at S-5A and S-6 for a number of yenrs. Nny ellects of altered water quality on vegetation should be most obvious at these places. For this reason we surveyed or sampled the plant communities in the vicinily of S-5A and the Hillsboro canal below $S-6$, and for comparison, the commilies in the vicinity of $5-9$, and Lhe Interior marshes of the Everglades.

\section{Resul1:s}

lhe danals mear $5-5 \mathrm{~A}$ are heavily infosted with the submerged exoltc hydrilla, Hycluilla vorticillata. The large reed, fliragmitcs australis, is clominant at the cunal edge. The nearby marsh has dense cattail stands (Typha $\mathrm{sp}$ ) and ponded areas with flotting, and submerged exotjc plants. Platits such as Pistia stratoles, Lomna, Salvinia, A7olla, Mlternathara philoxeroldes, and filimentous grecn algac are locilly abundant.

Cattail is the dominanc errergent plant in the mashes near the tillsboro Canal, in both nreas 1 and 2; dense growth of this planl extends up to scveral kilometres lrom the cunal. Other large plants are virtually absent. over larga areas. North of che llillsboro canil there are also large ponded arcas of open waler wj th predominatily submerged plants.

AL pumping station $\$-9$ canal banks are also characterized by havy and intermixed stands of cattail und Phxagmites tublralj.s, Interspersed are patches of yel1ow water lily. Nuphar luteum. Hydrilia, bladderwort, Najas, 
and Cabomba caloliniana are abundant. The peripheral marshes have intermixed stancls of cattai lind sawgrass.

Dense stands of cattail occur in the Everglades near canals, along airboat trails, or around tree islands. In the interior tvorglades cattails are not usually abundant except for large stands around some tree islands and near the mangrove fringe. The denge stands of callall in the conservation areas arc probably good inclicators of disruption and atress on sawgrass. Many ponded arcas, near the large cands in the northern comgervation areas are infested with exotic submerged or floating $p$ ints that are also indicat.ve of disruption. DLstulion of the Everglades plant comminilies may reflect one or a combination of lactors inclubling altered wator levels, allered water quality, destruction of existing comminities, or opening routes of access by chamclization.

Aquatic plant biomas was sampled at four slough locations j.n Conservation Area 1 (Hasic data F). Two of the locations were near pumping station S-5A; the other locations wore in axeas remole from pumping, l'lants in the quadrats were removed whole, including roots, separated into species, and weighed wel in the ficld. Subsamples were returned to the laboratory, oven. driod, and weighed.

Total wet weight rangel from 397 to $25,410 \mathrm{gm} / \mathrm{m}^{2}$. Because of the large variation at any one location no sirnllicant differences in biomass between the locations ware evident. Species composition differences were obvious how ever. Floating and submerged plants, including Hydrilia verticillata A] tornanthera philoxeroides and Najas quadalupensis, were dominant in bLomass at locations near S-5A. Cattail was the dominant cmergent plant. In the quadrats in the interior of Ares 1 the dominant emergent vegetation included Nymphaea odorata, Eleocharis, Rhynchospora tracyi and Pontederia lanceolata.

Selected mutrients and trace elements were measured in a varlety of marsh plants. Samples of several common plant species were collected iri areas of relatively poor quality water (S-5A and $S=10$ structures) and in areas of relatively good quality wacer (thi. interior marshes of the conservation arcas). Results for cach species are given in Tuble 10.

Nutrients, such as nilrogen, phosphorus, and carbon, and potontially toxic metals, such as copper, lead, and zinc are oflen associated with agricu1tural or urban runoff. These might be expected to be in higher concantration in plants near $s-5 \Lambda$ and $s-L O C$ than in plants from the inlerior marshes, No such trends were evident, however, wlth the possible cxception of phosphorus. samplcs ol catiail from 5-5A had a higher average concentration of phosphorus $(2.2 \mathrm{mr} / \mathrm{g})$ than those from other locations (1.0 Lo $1.2 \mathrm{mg} / \mathrm{g})$. Also, the overal. average for all spocies was highet in this element aL $S-5 \Lambda$ and at $s-10 \mathrm{C}$ (2.2. to $2.4 \mathrm{mg} / \mathrm{g})$ than at the olher locations $(0.8$ to $1.4 \mathrm{mg} / \mathrm{g})$. The highest concentration of lead (2l $\mu \mathrm{g} / \mathrm{kg}$ ) was surptisingly in a catiail sample from a remote region ol Conservation Araa $3 \mathrm{~A}$. 
Table 10.--Concentrations of mutrients and trace elements (totals) in aquatic plants from the water conservation areas. (Plants were collected January 1973. Location of sampling sites shown on figure 3 and 5B.)

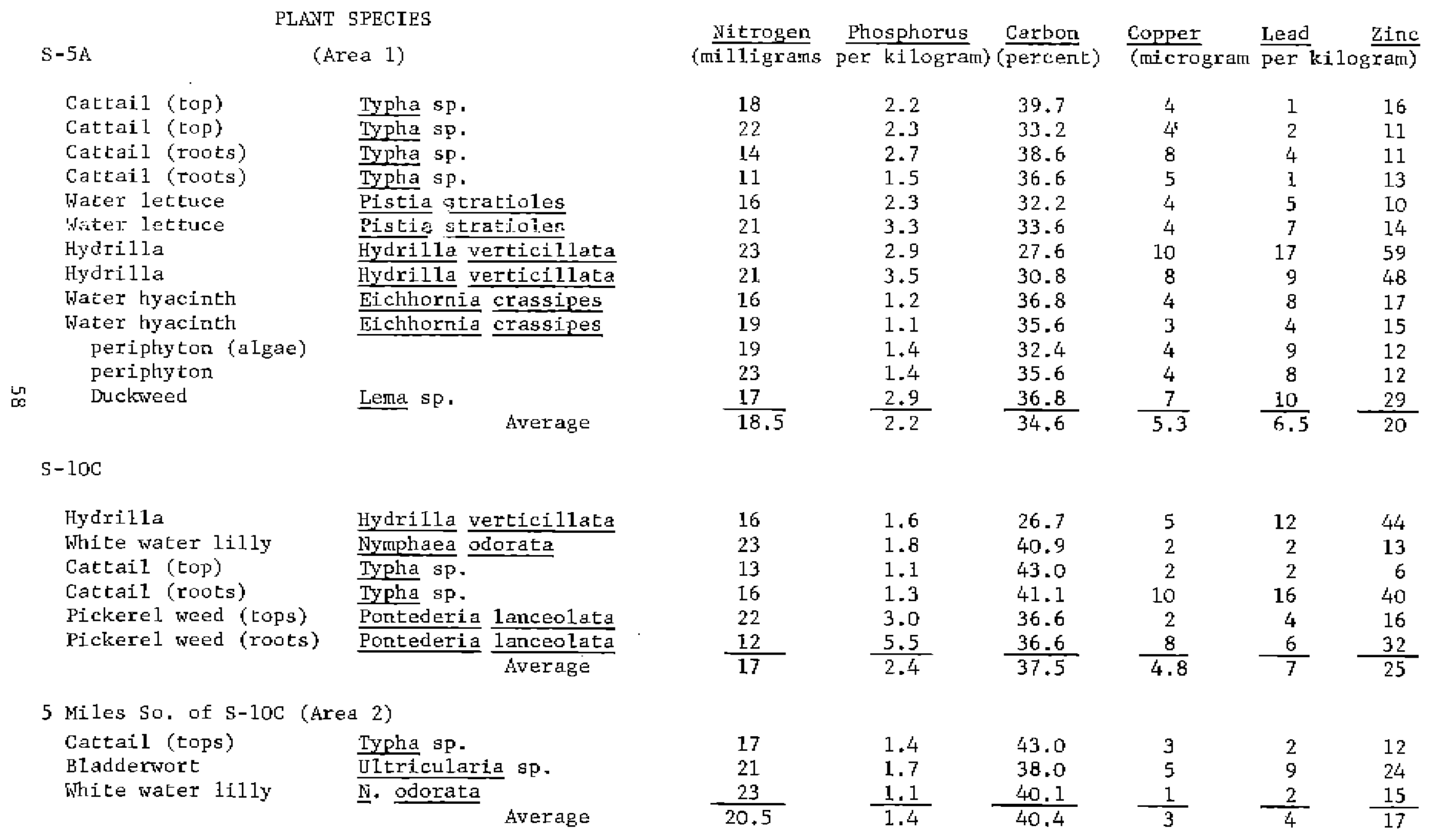


Table 10.-Continued - Concentrations of nutrients and trace elements (totals) in aquatic plants from the water conservation areas. (Plants were collected January 1973 . Location of sampling sites shown on figure 3 and 5 B.

PLANT SPECIES

(Area 2)
Nitrogen Phosphorus Carbon Copper Lead Zinc (uilligrams per kilogram) (percent) (Microgram per kilogram)

2-17 (Center of Area 2)

White water li1y

N. odorata

24

1.1

41.7

2

2

Interior of Area 1

BLaddertort

Cactail (top)

Arrowhead

L'1ericularia sp.

Iypha sp.

Pickerelweed (tops)

white water lilly

Sagittaria lancifolia

Pontederia 1anceolata

i. odorata

Average

\begin{tabular}{cc}
15 & .77 \\
18 & 1.1 \\
26 & 1.8 \\
18 & 1.3 \\
24 & 1.3 \\
\hline 20.5 & -1.2
\end{tabular}

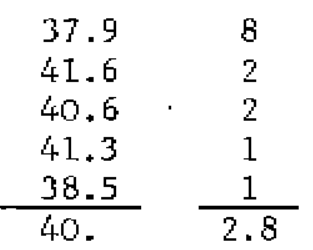

$\begin{array}{r}5 \\ 3 \\ 3 \\ 3 \\ 3 \\ \hline 3.4\end{array}$

56

$1 \mathrm{I}$

32

18

$\frac{31}{29}$

L

Cattail (top)

Cattai1 (roots)

(Area 3)

Pickerelweed (tops)

Pickerelnecd (roots)

$\frac{\text { Typha sp. }}{\text { Typha sp. }}$
P. Ianceolata
P. Ianceolata

P. 1anceolata

Average

\begin{tabular}{ll}
15 & .99 \\
11 & .96 \\
21 & 1.5 \\
11 & 1.6 \\
\hline 14 & 1.3
\end{tabular}

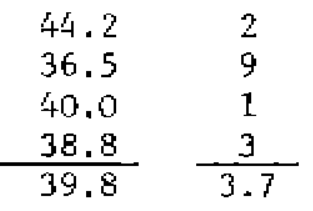

\begin{tabular}{rr}
2 & 9 \\
21 & 19 \\
3 & 13 \\
7 & 26 \\
\hline 8 & 17
\end{tabular}

$3-28$

Write water Eilly

N. odorata

Bacopa

Bacope caroliniana

\begin{tabular}{l}
21 \\
11 \\
\hline 16
\end{tabular}

$\begin{array}{r}.91 \\ .64 \\ \hline .77\end{array}$

\begin{tabular}{ll}
41.7 & 1 \\
36.1 & -7 \\
\hline 39.1
\end{tabular}

\begin{tabular}{ll}
3 & 29 \\
7 & 27 \\
\hline 5
\end{tabular}$\quad \begin{aligned} & 28\end{aligned}$ 
Water to sustain the marshes of the conservation areas and Everglades National Park is from direct rainfall and from canals which convey witer frorl Lake okeechobee and from agricultural lands in the north. Water filows southward in the canals by gravj.ty or is pumped southward into the conservation arcas. The thrce conservation areas are connccted by spillway structures that enable water to be transferred directly from take okeechobee through Conservation Arca 3 and thence to Evergl,ades National. Jark or, during drought, to the Mi.min. area. In addlion, water can be backpumped from thc aat into Conservation Area 3A at pumping station S-9.

Plans for further water management in southeast florida include reduction of storm runofe to the coastal areas by larre increases in backpumping to the conservation areas. Such backpumping would alter water levels and introducc additional nutrients and pollutants into the tverglades environment. The degree of change in water chemistry in the conservation areas would depend main*ly on the quality and quantity of the water backpumped. With additional backpumping, the conservation arcas would become wetter and this would tend to jncrease aquatic plant communitics in relation to semi-aquatic commoilies.

Such changes have already been recorded in parts of the conservation arans where water levels have been increased by impoundrient. Land to the cast of the conservation areas would become dricr with backpumping, and this would tencl lo increasse the development potential of this land.

Water pumped into the conservation areas is now lingely confined to canals and peripheral marshes of Area 1 and 3 . In area 2, howcver, canal water extends into the interior marshes.

Water pumped into the northem Everglades often has relatively high cuncentrations of inorganic nitrogen and phosphorus which are transported in the canals or move into the peripheral marshes. Concentrations of nitrogen and phosphorus decrease sharply within 100 metres or less of the canals, whereas specific conductance remains essentially unchanged within that distance. The sharp decrease in inorganic nitrogen and phosphorus alomg the canal edge indicates net uptake in these shallow waters.

Concentrations of total phosphorus and inorganic nitrogen decreased an average of 3 percent and 4 percent per kilometre respectively downstream In canals in the conservation areas. This decrease is due partly to dilublon by rainfall and runoff, and partly to net uptake in the canals and peripheral marsh.

Measurements of dissolved oxygen suggest that nutrient uptake from canal water by aquatic biota occurs minly near the edge of the canal and in nearby marshes. First, diel fluctuations of dissolved oxygen in the large canals in January 1973 and 1974 and september 1973 were relatively smal1, indicating a low biological metabolism with little uptake or release of nucrients. Second, dissolved oxygen decreased with depth, often to near anaerobic levels near the bottom of the canals. This suggests that the dominant melaholic procass was respiration which would release nutrlents to the water. Third, conccntrations of dissolved oxygen tended to increase near the canal bank and in the nearby marshes, Low-flow or stagnant condjtions, however, would probably allow 
planklon to bloom resulting in increased photosynthesis and nutrient uptake.

Pumping water into the conservation areas has geveral local elfects on. watcr chemistry in canals near the pumping stations. First, it introduces new water, often of a different quality, into thc conservation area canals. At pumping station S-9, for example, water backpumped into Conservalion Mrea $3 \mathrm{~A}$ is usually rich in ammonia and virtually devoid of dissolved oxypen, apparently becalise it is partly of ground-water origin. After backpumpinf, concentran tlons of dissolved oxygen are clepresscd and concentrations of ammonia are clevated at Leagl several kilometres domstream from the pump. Second, pumping breaks up stralification and mixes the different waters. At pumping station S-5A dissolved oxygen became almost uniform with depth after pumping began. Also, concentrations of amonia increased sharply downstroam with pumping, possibly because of a mixing effect that released ammonia from bottom sed$i$ ments. The high concentrations of ammonia and low concencrations of dissolved oxygen associated with pumping are, undcr present water-level conditions, confined primarily to cankls in the conservation areas.

Backpumping from the cast coast cants, which now occurs only at station $s-9$, added 230 tomnes (253 tons) ol: nitrogen and 1.8 tomnes (2 tons) of phosphorus to Comservation Area 3 from July 1972 through June 1973 (Waller, 1975). Additional pumping stations will allow as moch as 50 percent of total andul canal runoff in southeast florida to be backpunped. Annual.ty this would ackl from 900 Lo 5,600 tommes (990 to 6,160 tons) of nitrogen and lrom 9 to 56 connes (10 to 62 tons) of phosphorus to the conservation areas. For comparison, rainfall, ancl dry fulloul contributed 5,200 tonnes (5,700 tons) of nitrogen and 207 tomes (228 tons) of phosphorus to the conservation areas lrom July 1972 through June 1973 (Waller, 1975).

Direct rainfall and dry faljout are the major contributors of nitrogen and phosptiorus to the conservation arcas. Practically atl this falls on the marsh envi ronment where it is sulyect to biological uptake. lihe marsh sediments are a sink for those elements. Bottom sediments can also be a source of nitrogcri and phosphorus when anacrobic conditions exist at rhe water-scdiment intorface or when resusponsion of the bottom material occurs.

With respect to organic carbon and nitrogen, phosphorus is onriched in canal sediments compred with marsh sediments. Nlso there is some inclication that nitrogen and phosphorus and several trace metals axe enriched in canal sediments near puruping stations that drain agriculcural land compared with carlal sedimonls remote from pumping stalions.

The plant communities of the Everglades are often discupted in the vicinity of large canals. Saw grass miath, sloughs, and wet prairios have becn altered or replaced by caltails or by submerged, flonting, and exotic plants. The disruption of the orifrinal plact communites ma roflect altored water levels, altered water puality or a combination of the two.

The plant ommunities near tho large canals in the notblem Everglacles aro of ter exposed lo agricultural runofic and to water of poor quality compred with the waler quality in tha jalerior marshes. Thirty-four samples of acjuatic plant spcites collected in these canals and the intcrior marshos were analynod for nitroger, phosphorus, carbor, copper, leat, and oinc. Txcept for slightly 
hjgher concentrations of phosphorus in plant tissue from two locations where water quality is poor, ro differences in nutrient and metal concentrations were evldent in aquatic plants collected either from remote, relatively undisturbed areas or from areas recciving agricultural runoff.

\section{SELECIED REFERENCES}

Alexander, 'l.R., and Crook, A.G., 1.974, kecent and long-term vegetation changes and patterns in South Florida; Natl. 'lech. Inf. Service. 1'b-231-939.

Central and Southern Florida Flood Control Distrlot, 1973, Jreliminary evaluation report on land and watcr management planming in the $\mathrm{G}-5 \mathrm{I}$ watershed.

Treiberger, H.J., 1973, Elfects of backpumping from South New River Cana1 Pump Station $S-9$ on qualicy ol" water in water-conservation Area 3, hroward Counly, Florjda: U.S. Gcol. Survey open-file report 73026.

Glesson, P.J., 1974, Chemical. quality of water in Conscrvation Area 2A arul assouiated canals. FCD Tech, l'ubl. 非4-1.

Gleasori, F.J. and Spackman, W., Jr., 1974, Calcarcous periphylon and water chomistry in the Everrlades. In Enviroments of South Florida: l'resent and Past: Memoir 2, Miami Gool. Soc., Miami, Florida.

Hagenbuck, W.W., Thompson, $\mathbb{R}_{*}$, and Rodgers, D.P., 197/, A preliminary investigation of. the affects of water levels on vegetative comnunities of Loxahatchec National wildlife Reluge, Plorida: Natl. Tech. Inf. Servica $I^{2} 3-231-611$.

Klein, Howarcl, Ambruster, JefFrey, Mclhersom, B.F. and Treiberger, H..., 1974, Water and the South Florida Tnvironment: Natl. Tech. Inf. Services, PB-236-951.

Loveless, C.M., 1959, A study of the vegetation of the rlorida tiverglades: Ecology, v. 40, no. 1 ,

Mctherson, H.F., 19\%3, Water cuality in the conservalion areas of the contral and Southern Plorida Flood Control District, 1970-72: U.S. Cieol. Survey open-file report T3014.

Ornes, W.H. and Stewaxd, K.K., 1974, Tifects of phosphorus and potassium on phy coplatikton popularions in ficld enclosures: Nall. Tech. Int. Servicc, $\mathrm{PB}-231-650$.

parker, G.G., Ferguson, G.E., Jove, S.K., and others, 1955, wacex resources of southeastorn Florida: IT,5, Gcol. Survey Water-Supply Paper 1255.

5taward, K.K., and ornes, W.H., 1974a, Investigations into the mineral mutrition of sawgrass using experimencal culture techni ques: Natl. 'lech. Inf. Service, ${ }^{\prime} \mathrm{H}_{\mathrm{j}}-231-6009$. 


\section{SLLECTED REFERENCES (Continued)}

Steward, K.K., and Ormers, W.H., 1974b, the autecoloty of sawgrass (Mariscus jamiccinsis) in the Florida Everglades: Natl. Tech. Inf. Service, $\mathrm{PB}-231-608$.

U.S. Army Corps of Engineers, 1968, water resources for central and southern Florlda: Jacksonville, Florida.

Waller, B.G., 1975, Distribution of Nitrogen and Phosphorus in the ConservitLLon Areas of South Florida July 1972 - June 1973: U.s. Geol. Survey Water-Resources Tnv, 5-75.

Waller, B.G. and Earle, J.E., 1975, Chemical and Biological Quality of Water in a Part of the Everglades, Southeastern Florida: U.S. Geol. Survey Water-Resources Inv. 56-75.

Wacer and $\Lambda$ ir Research, Inc. 1971, Water quallty study, Fverglades National Park: U.S. Army Corps of Engineers Contract DAC W17-71-C-0031. 
BASIC DATA A

Nutrient Transects, September 10-11, 1973 and January $16-17,1974$. 
Transects from canals into the marshes of the conservation Areas on September 10-11, 1973. Locations of transects shown on Figure 3.

Transects B, C, D, E cross canals.

Distance in metres from canal (s)

T

Temp DO

$\underline{\mathrm{C}} \mathrm{mg} / 1$

$$
\begin{aligned}
& \text { Specilic } \\
& \text { Conductance }
\end{aligned}
$$

micromhos $/ \mathrm{cm}$

\begin{tabular}{|c|c|c|c|}
\hline & & $\mathrm{mg} / \mathrm{I}$ & \\
\hline $\begin{array}{l}\mathrm{PO}_{4} \\
\mathrm{a}=\mathrm{P}\end{array}$ & $\begin{array}{l}\mathrm{NH}_{3} \\
\text { as. } \mathrm{N}\end{array}$ & $\begin{array}{l}\mathrm{NO}_{2} \\
\text { as } \mathrm{N}\end{array}$ & $\begin{array}{l}\mathrm{NO}_{3} \\
\mathrm{a}: \mathrm{N}\end{array}$ \\
\hline
\end{tabular}

at $25^{\circ} \mathrm{C}$

Transect A

$\begin{array}{ccccc}1015 & 0.008 & 0.18 & 0.000 & 0.00 \\ 1015 & - & - & - & - \\ 1025 & - & - & - & - \\ 900 & .010 & .22 & .000 & { }_{0} 00\end{array}$

Transect B (East to West)

$\begin{array}{ll}28.0 & 0.8 \\ 27.5 & 1.3 \\ 28.0 & 1.1 \\ 27.5 & 2.0 \\ 27.5 & 2.0\end{array}$

940
1175
1015
1130
875

$.008 \quad .18$

$.010 \quad .42$

.000

.00

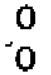

1,600

4,000

3,200
0
0
2,400
7,200
13,600
15,000

27.0

28.5

3.5

2.5

$29.0 \quad 6.8$

$28.5 \quad 3.8$

$28.0 \quad 2.6$

$28.5 \quad 1.8$

$29.0 \quad 2.8$

$30.0 \quad 2.4$

$28.0 \quad 1.6$

$28.0 \quad 0.9$

$28.0 \quad 6.5$

$28.0 \quad 5.7$

$28.0 \quad 6.4$

$31.0 \quad 9.4$

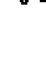

$\begin{array}{cccc}- & - & - & - \\ .000 & .19 & \text { „000 } & .00\end{array}$

Transect C (South to North)

$\begin{array}{ccccc}910 & .005 & .12 & .000 & .00 \\ 1020 & .004 & .16 & .000 & .00 \\ 1010 & - & - & - & - \\ 1020 & - & - & - & - \\ 1015 & - & - & - & - \\ 1255 & .003 & .13 & .000 & .01 \\ 1020 & - & - & - & -\end{array}$

Transect D (southwest to northeagt)

$\begin{array}{lllll}1020 & .006 & .17 & .000 & .00 \\ 1335 & .037 & .43 & .000 & .21 \\ 1345 & .032 & .40 & .048 & .15 \\ 1315 & .010 & .20 & .000 & .00 \\ 705 & .005 & .12 & .000 & .00 \\ 660 & .010 & .12 & .000 & .01 \\ 245 & .005 & .16 & .000 & .00 \\ 105 & .004 & .11 & .000 & .00\end{array}$


Continued - Transects from canals into the marshes of the Conservation Areas on September 10-11, 1973. Locations of transects shown on figure 3 .

Transects B, C, D, I cross canals.

Distance in metres from canal.(s)... specific

Conductance

Temp DO micromhoskm $\mathrm{PO}_{4} \quad \mathrm{NH}_{3} \quad \mathrm{NO}_{2} \quad \mathrm{NO}_{3}$ $\stackrel{\circ}{\circ g} / 1$ at $25^{\circ} \mathrm{C}$ as $\mathrm{P}$ as $\mathrm{N}$ ag $\mathrm{N}$ as $N$
TrFansect $\mathrm{E}$

$\begin{array}{ll}28.0 & .05 \\ 28.5 & 2.2 \\ 29.0 & 4.4 \\ 30.0 & 7.6 \\ 28.5 & 1.2 \\ 29.0 & 6.1 \\ 30.0 & 6.1\end{array}$

920

885

920

830

540

180

110

.026
.036
.005
.010
.007
.008
.006

.20

$\begin{array}{lll}30 & .000 \quad .00\end{array}$

$.13 \quad .000 \quad .03$

$.13 \quad .000 \quad .00$

$.07 \quad .000 \quad .00$

$.16 \quad .000 \quad .00$

$.15 \quad .000 \quad .00$

Transect F (West to east)

$\begin{array}{ccc}0 & 28.5 & 1.7 \\ 100 & 26.5 & 1.0 \\ 500 & 26.0 & 3.2 \\ 1700 & 27.0 & 6.4\end{array}$

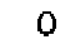

100

500

2100

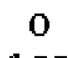

100

500

1300

2100

2900

$\begin{array}{rrrrr}1080 & .036 & .62 & .100 & .41 \\ 850 & .012 & .21 & .000 & .00 \\ 445 & .015 & .21 & .000 & .00 \\ 130 & .012 & .23 & .000 & .00\end{array}$

\section{I'ransect $G$}

$\begin{array}{rllll}1040 & .050 & .92 & .048 & .14 \\ 400 & .012 & .32 & .000 & .00 \\ 200 & .025 & .33 & .000 & .00 \\ 115 & .025 & .38 & .000 & .00\end{array}$

\section{Transect $\mathrm{H}$}

$\begin{array}{lllll}820 & .042 & .40 & .000 & .00 \\ 780 & .023 & .20 & .000 & .00 \\ 370 & .006 & .15 & .000 & .00 \\ 270 & .009 & .17 & .000 & .00 \\ 180 & .007 & .19 & .000 & .00 \\ 150 & .012 & .42 & .005 & .00\end{array}$


Continued - Transects from canals into the marshes of the conservation areas on September 10-11, 1973. Locations of transects shown on figure 3 .

Transects B, C, D, E cross canals.

Distance in metres from canal $(s)$
Specilic conductance Tenp DO micromhos/cm $\mathrm{PO}_{4} \quad \mathrm{NH}_{3} \quad \mathrm{NO}_{2} \quad \mathrm{NO}_{3}$ ${ }^{\circ} \mathrm{C} \quad \mathrm{mg} / 1$ at $25^{\circ} \mathrm{C}$ as $\mathrm{P}$ as $\mathrm{N}$ as $\mathrm{N}$ as $\mathrm{N}$

Area 1 near center

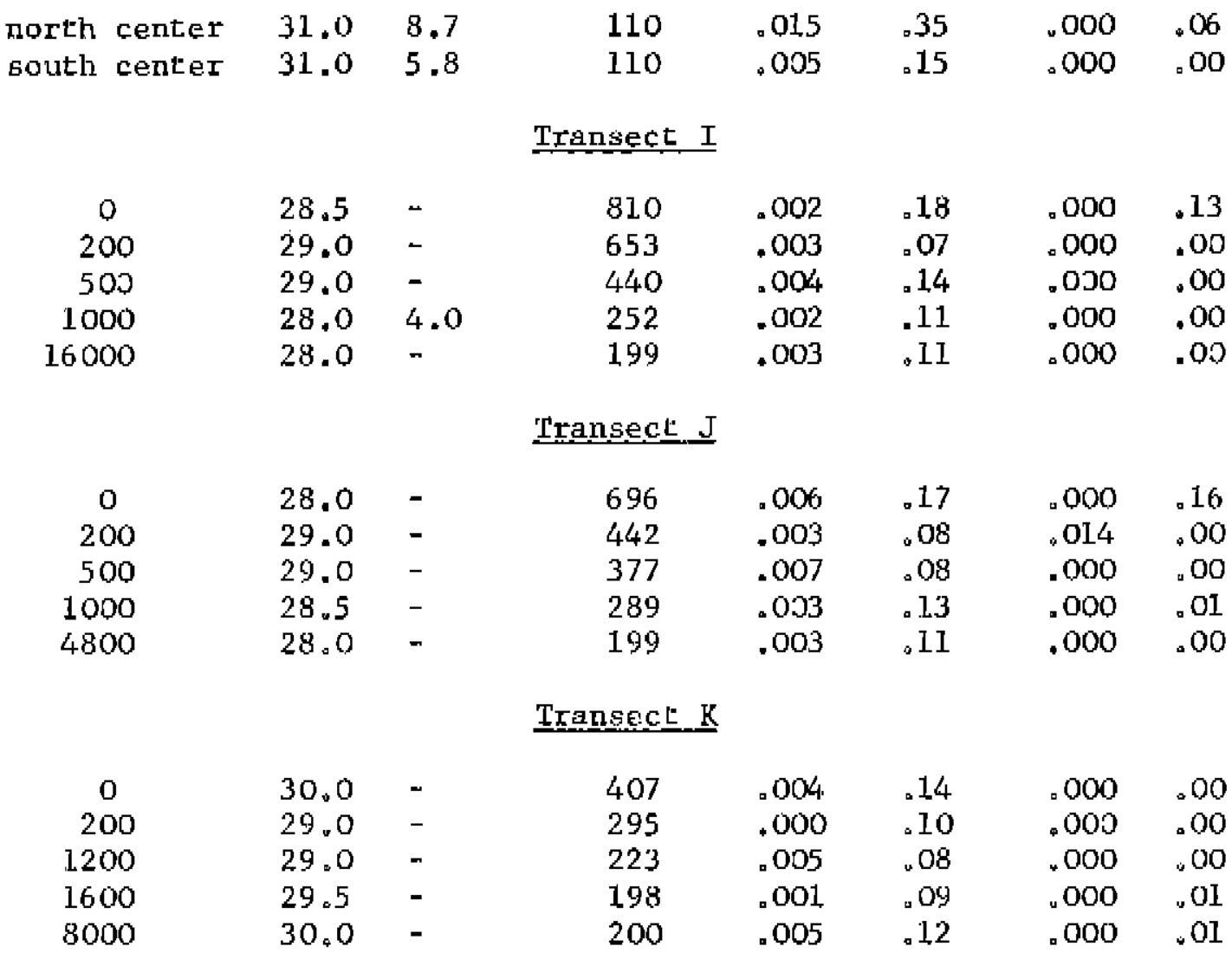


-Transects from canals into the marshes of Conservation Area 1 on 16-17 January 1974. Distance from canal is in meters

(approximate). Transect locations are shown on Figure 3.

Distance

in meters
Specific

D.o. Conductance $\overline{\mathrm{PO}}_{4} \mathrm{HH}_{3} \quad \mathrm{NO}_{2} \mathrm{NO}_{3}$ $\mathrm{mg} / 1$ micromhos/cm as $\mathrm{P}$ as $\mathrm{N}$ as $\mathrm{N}$ as $\mathrm{N}$

$\begin{array}{lll}0 & 1300 & 21.5 \\ 10 & 1303 & 22.0 \\ 20 & 1306 & 22.0 \\ 100 & 1309 & 22.1 \\ 500 & 1312 & 23.5 \\ 2000 & 1315 & 25.0\end{array}$

0

10

20

100

400

1500

0

10

20

100

400

1000

0

10

20

100

500

2500

0

10

20

100

500

1500

3000

4500
$1320 \quad 21.0$

$1325 \quad 22.9$

$1328 \quad 24.0$

$1330 \quad 23.2$

$1335 \quad 22.2$

$1337 \quad 24.5$

\section{$1410 \quad 24.0$}

$1412 \quad 24.0$

141423.0

141624.0

$1418 \quad 24.0$

$1420 \quad 24.5$

1010

1012

1014

1016

1018

1020

21.0

21.0

21.0

21.0

20.5

20.5

$1045 \quad 21.5$

$1048 \quad 21.5$

1050

1052

1054

1056

1058

1100
21.5

22.0

20.0

20.5

20.5

21.5
Transect $\mathrm{L}$

6.41300

2.01300

4.2800

6.8 210

6.9100

$\frac{\text { Transect }}{2.2} \frac{M}{1240}$

2.31310

4.51390

4.11480

7.5 280

$7.1 \quad 140$

Transect $\mathrm{N}$

$4.4 \quad 490$

$4.7 \quad 570$

$4.1 \quad 580$

8.0 355

6.7180

7.3 I05

$\frac{\text { Transect } 0}{3.9}$

$3.6 \quad 440$

3.3420

3.6190

$4.3 \quad 110$

$3.4 \quad 52$

$\frac{\text { Transect } P}{2.2 \quad 1280}$

$2.8 \quad 1250$

3.51280

$4.8 \quad 1310$

$3.1 \quad 1100$

4.5980

4.6500

5.0200
0.14

0.73

0.09

0.51

0.09

0.51

0.15

0.51

0.09

0.56

0.15

0.46

$\begin{array}{lllll}0.01 & 0.11 & 0.00 & 0.00\end{array}$

$0.01 \quad 0.18$

0.00

0.00

0.14

0.65

0.07

0.51

0.12

0.57

$\begin{array}{ll}0.11 & -0.52\end{array}$

0.04

0.37

0.15

0.37

$0.01 \quad 0.35$

0.08

0.07

0.01

0.11

0.00

0.00

0.01

0.00

0.00

$\begin{array}{llll}0.02 & 0.21 & 0.00 & 0.14 \\ 0.02 & 0.17 & 0.00 & 0.03 \\ 0.02 & 0.20 & 0.00 & 0.04 \\ 0.00 & 0.09 & 0.00 & 0.00 \\ 0.00 & 0.11 & 0.00 & 0.00 \\ 0.00 & 0.12 & 0.00 & 0.00\end{array}$

$\begin{array}{llll}0.01 & 0.14 & 0.00 & 0.01 \\ 0.02 & 0.36 & 0.00 & 0.00 \\ 0.01 & 0.18 & 0.00 & 0.00 \\ 0.00 & 0.13 & 0.00 & 0.00 \\ 0.00 & 0.11 & 0.00 & 0.00 \\ 0.01 & 0.18 & 0.00 & 0.00\end{array}$

$\begin{array}{lllll}0.03 & 0.44 & 0.06 & 0.24\end{array}$

$\begin{array}{llll}0.02 & 0.29 & 0.03 & 0.28\end{array}$

$\begin{array}{lllll}0.01 & 0.20 & 0.03 & 0.25\end{array}$

$\begin{array}{lllll}0.00 & 0.28 & 0.04 & 0.16\end{array}$

$\begin{array}{lllll}0.00 & 0.13 & 0.00 & 0.00\end{array}$

$\begin{array}{llll}0.00 & 0.12 & 0.00 & 0.00\end{array}$

$\begin{array}{llll}0.00 & 0.08 & 0.00 & 0.00\end{array}$

$\begin{array}{llll}0.00 & 0.12 & 0.00 & 0.00\end{array}$ 
Specific

D.0. Conductance $\mathrm{PO}_{4} \quad \mathrm{NH} 3 \mathrm{NO}_{2} \mathrm{NO}_{3}$

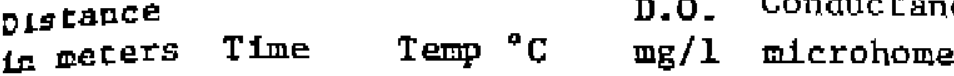

0

20

100

500

1200

2500

4500

North

South
1120

$1122 \quad 22.0$

$1124 \quad 22.0$

$1126 \quad 20.5$

$1128 \quad 21.0$

$1130 \quad 20.5$

$1135 \quad 22.0$

$1345 \quad 23.6$

$1430 \quad 23.2$ $\frac{\text { Center of Conservation inea I }}{6.5}$
Transect $Q$

5.2720

5.8800

5.3620

5.8500

6.3450

$7.5 \quad 240$ $\begin{array}{lllll}0.01 & 0.16 & 0.00 & 0.03\end{array}$

$\begin{array}{lllll}0.01 & 0.11 & 0.00 & 0.02\end{array}$

$\begin{array}{llll}0.00 & 0.12 & 0.00 & 0.00\end{array}$

$\begin{array}{llll}0.01 & 0.13 & 0.00 & 0.00\end{array}$

$0.00 \quad 0.10 \quad 0.00 \quad 0.00$

$0.00 \quad 0.08 \quad 0.00 \quad 0.00$

$\begin{array}{llll}0.00 & 0.10 & 0.00 & 0.00\end{array}$

$\begin{array}{rrrrrr}8.5 & 95 & 0.00 & 0.16 & 0.00 & 0.00\end{array}$


Transects from canals fnto the marshes of Conservation Areas 2 and 3 on 16-17 January 1974 . Distance from canal is in meters (approxirute). Transect locakions suown on Figure 3 . Specific $\mathrm{mg} / 1$

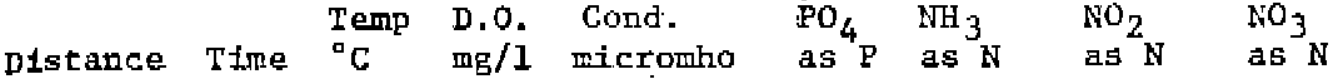

\begin{tabular}{|c|c|c|c|c|c|c|c|c|}
\hline & & & & Transect $R$ & & & & \\
\hline 0 & 1230 & 22.2 & 2.8 & 800 & 0.00 & 0.44 & 0.00 & 0.06 \\
\hline $10(1)$ & 1235 & 21.5 & 2.0 & 780 & 0.00 & 0.13 & 0.00 & 0.00 \\
\hline 20 & 1240 & 21.0 & 1.0 & 780 & 0.00 & 0.12 & 0.00 & 0.00 \\
\hline 200 & 1240 & 20.0 & 1.5 & 750 & & & & \\
\hline 4000 & 1246 & 220 & 3.0 & 750 & 0.00 & 0.13 & 0.00 & 0.00 \\
\hline & & & & Transect $S$ & & & & \\
\hline & 1345 & 22.0 & 1.7 & 1200 & 0.04 & 0.35 & 0.00 & 0.1 \\
\hline & 1350 & 22.0 & 2.9 & 1100 & 0.00 & 0.1 .6 & 0.00 & 0.0 \\
\hline 0 & 1352 & 19.5 & 1.7 & 600 & 0.00 & 0.12 & 0.00 & 0.0 \\
\hline 500 & 1355 & 21.5 & 3.4 & 820 & 0.00 & 0.13 & 0.00 & 0.0 \\
\hline
\end{tabular}

\begin{tabular}{|c|c|c|c|c|c|c|c|}
\hline & & & & Transect $\mathrm{T}$ & & & \\
\hline $\begin{array}{c}0 \\
20\end{array}$ & $\begin{array}{l}1355 \\
1357\end{array}$ & $\begin{array}{l}23.0 \\
22.5\end{array}$ & $\begin{array}{l}1.6 \\
2.8\end{array}$ & $\begin{array}{l}1050 \\
1100\end{array}$ & $\begin{array}{l}0.00 \\
0.01\end{array}$ & $\begin{array}{l}0.64 \\
0.32\end{array}$ & $\begin{array}{l}0.00 \\
0.00\end{array}$ \\
\hline
\end{tabular}

\begin{tabular}{|c|c|c|c|c|c|c|c|c|}
\hline & & & & Trausect IJ & (Atea & $3 \mathrm{~A}$ to & 2B) & \\
\hline 2500 & 1405 & 20.0 & 2.6 & $8 \overline{860}$ & 0.01 & 0.16 & 0.00 & 0.00 \\
\hline 0 (west) & 1410 & 22.0 & 4.4 & 1000 & 0.01 & 0.18 & 0.00 & 0.04 \\
\hline 0 (east) & 1418 & 24.0 & 6.9 & 910 & 0.00 & 0.20 & 0.00 & 0.24 \\
\hline 200 & 1420 & 24.5 & 2.6 & 980 & 0.00 & 0.14 & 0.00 & 0.00 \\
\hline of $2 \mathrm{~B}$ & 1425 & 26.0 & 5.3 & 890 & 0.00 & 0.10 & 0.00 & 0.00 \\
\hline
\end{tabular}

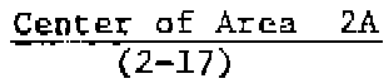

$1310 \quad 21.5 \quad 4.4 \quad 1080$

(1) The second sample site, Transect $R$, in the marsh west of levee. There was no canal west of levee. Canal on the east.

(2) Transect run due wast into Conservation Area 3 from S-11C. Water was flowing west through S-11C. Transect stopped because of dfy conditions. 
Transect from S-39 southwest along airboat trail into the marshes of area 2. I6-17 January 1974, Distance $\mathrm{Erom} 3-39$ in meters

(approximate)

$\begin{array}{llllll} & & & \mathrm{mg} / \mathrm{I} \text { as } \mathrm{N} \\ \text { Time Distance Temp } & \mathrm{D} .0 . & \text { Specific } \mathrm{PO}_{4} & \mathrm{NH}_{3} & \mathrm{NO}_{2} & \mathrm{NO}_{3} \\ \text { EDST in meters }{ }^{\circ} \mathrm{C} & \mathrm{mg} / 1 & \text { Conductance as } \mathrm{P} \text { as } \mathrm{N} & \text { as } \mathrm{N} & \text { as } \mathrm{N}\end{array}$

\section{Transect $\mathrm{V}$}

January 16,1974

$131510 \quad 24.5$

$1520100 \quad 24$

$1530 \quad 240 \quad 24$

$\begin{array}{lll}1535 & 300 \quad 24\end{array}$

$\begin{array}{lll}1545 & 1600 \quad 24\end{array}$

$1600 \quad 5000 \quad 24$

$1610 \quad 8000 \quad 24$

$\begin{array}{ccccc}1380 & .03 & .38 & .04 & . .06 \\ 1340 & .01 & .29 & .02 & .06 \\ 1150 & .01 & .18 & .00 & .01 \\ 1165 & .01 & .22 & .00 & .00 \\ 1360 & .01 & .13 & .00 & .00 \\ 1120 & .00 & .16 & .00 & .00 \\ - & - & - & - & -\end{array}$

January 17,1974

$\begin{array}{lllllllll}0935 & 10 & 21.5 & 2.6 & 1325 & .03 & .58 & .04 & .06 \\ 0950 & 8000 & 20 & 1.9 & 1080 & .00 & .12 & .00 & .00 \\ 0955 & 10000 & 20.5 & 2.8 & 1025 & .00 & .12 & .00 & .00\end{array}$


BASIC DATA B

Concentrations of nutrients near $S-5 A$ on 16-17 January 1973 . 
Concentrations of nutrichts near 5-5A on 16-17 January 1973. Specific conductance in micromhos at $25^{\prime \prime} \mathrm{C}$. Acid hydrolizable $\mathrm{P}$ and $\mathrm{PO}_{4}-\mathrm{P}, \mathrm{NO}_{3}-\mathrm{N}, \mathrm{NO}_{2}-\mathrm{N}_{2} \mathrm{NH}_{3}-\mathrm{N}$, inorganic $\mathrm{N}$ and diasolved oxygen (DO) in mg/l. No pumping.

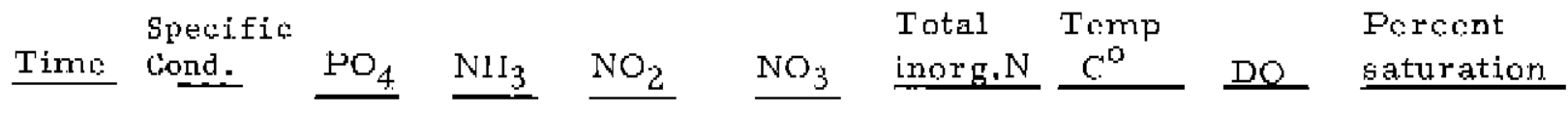

\section{Sitc I (West Palm Beach Canal)}

$\begin{array}{llllllllll}0810 & 1280 & .078 & .46 & .068 & .43 & .96 & 15 & 4.9 & 48 \\ 1220 & 1345 & .072 & .47 & .070 & .45 & .99 & 17 & 6.3 & 64 \\ 1600 & 1420 & .070 & .46 & .060 & .47 & .99 & 17 & 5.5 & 56 \\ 2200 & 1300 & .084 & .46 & .060 & .47 & .99 & 16 & 5.2 & 52 \\ 0005 & 1260 & .070 & .45 & .058 & .47 & .98 & 16 & 5.4 & 54 \\ 0405 & 1240 & .070 & .43 & .070 & .48 & .98 & 16 & 5.5 & 55 \\ 0745 & \frac{1220}{1295} & \frac{.084}{.076} & \frac{.42}{.45} & \frac{.059}{.064} & \frac{.48}{.46} & \frac{.96}{.98} & \frac{16}{16} & \frac{5.5}{5.5} & \frac{55}{55} \\ \text { Avg } & 1296 & & & .46 & & & \end{array}$

Site 2 (Below 5-5A)

\begin{tabular}{|c|c|c|c|c|c|c|c|c|}
\hline 1050 & 1330 & .042 & .37 & .077 & .37 & .82 & 15 & 6.9 \\
\hline 1330 & 1300 & .042 & .35 & .088 & .38 & .82 & 15 & 6.8 \\
\hline 1705 & 1170 & .042 & .31 & .094 & .41 & .81 & 16.5 & 6.5 \\
\hline 2040 & 1200 & .042 & .31 & .094 & .41 & .81 & 15.5 & 6.6 \\
\hline 0100 & 1200 & .045 & .30 & .090 & .42 & .81 & 16 & 6.4 \\
\hline 0440 & 1160 & .042 & .30 & .092 & .43 & .82 & 15.5 & 6.1 \\
\hline 0900 & 1260 & .040 & .28 & .088 & .39 & .76 & 15.5 & 7.0 \\
\hline Avg & $\overline{1230}$ & .042 & .32 & $\overline{0 R O}$ & 40 & 81 & $66^{\circ}$ & 76 \\
\hline
\end{tabular}

Site 3

$\begin{array}{llllllllll}1115 & .1310 & .042 & .34 & .060 & .35 & .75 & 11.5 & 6.7 & 64 \\ 1340 & 1320 & .056 & .36 & .064 & .36 & .75 & 15 & -- & -- \\ 2020 & 1200 & .056 & .33 & .068 & .38 & .78 & 16 & 6.3 & 63 \\ 0315 & 1230 & .054 & .32 & .068 & .36 & .75 & 16 & 6.1 & 61 \\ 0530 & 1220 & .042 & .32 & .066 & .37 & .76 & 16 & 5.9 & 59 \\ 0805 & \frac{1180}{1240} & \frac{.042}{.049} & \frac{.33}{.33} & \frac{.055}{.064} & \frac{.36}{.36} & \frac{.75}{.76} & \frac{15.5}{16} & \frac{6.4}{6.3} & \frac{63}{62} \\ \text { Avg. } & 1240 & & & & & & & & \end{array}$




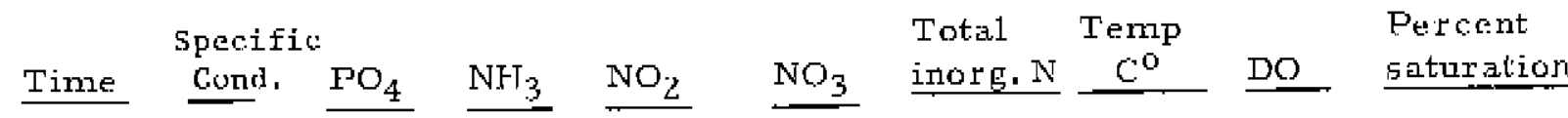

Site 4

\begin{tabular}{|c|c|c|c|c|c|c|c|c|}
\hline 1040 & 1270 & .042 & .31 & .086 & .39 & .79 & 14 & 6.9 \\
\hline 1320 & 1370 & .042 & .27 & .088 & .45 & .81 & 15 & 7.2 \\
\hline 2125 & 1200 & .042 & .27 & .086 & .43 & .79 & 15.5 & 6.7 \\
\hline 0050 & 1190 & .042 & $.2 B$ & .086 & .45 & .82 & 16 & 6.6 \\
\hline 04.50 & 1160 & .042 & .28 & .080 & .45 & .81 & 1.5 .5 & 6.3 \\
\hline 0850 & 1230 & .022 & .26 & .075 & .44 & .78 & 15.5 & 6.8 \\
\hline Avg & $\overline{1230}$ & .042 & $\overline{.28}$ & .084 &.$\overline{44}$ & .80 & 16 & 6.7 \\
\hline
\end{tabular}

Site 5

$\begin{array}{llllllllll}0945 & - & .028 & .24 & .066 & .60 & .91 & 14 & 6.8 & 65 \\ 1250 & 1125 & .050 & .25 & .066 & .63 & .95 & 15 & 7.9 & 78 \\ 1645 & 1180 & .028 & .23 & .068 & .63 & .93 & 16.5 & 7.1 & 72 \\ 2105 & 1140 & .028 & .22 & .068 & .62 & .91 & 16 & 7.5 & 75 \\ 0025 & 1160 & .039 & .23 & .068 & .64 & .94 & 15.5 & 7.3 & 72 \\ 0505 & 1120 & .022 & .22 & .070 & .63 & .92 & 15.5 & 6.8 & 67 \\ 0830 & 1130 & .027 & .20 & .060 & .59 & .85 & \frac{15.5}{16} & \frac{7.5}{7.3} & \frac{73}{72} \\ \text { Avg. } & 1.140 & .031 & .23 & .067 & .62 & .92 & 16 & \end{array}$

Site 6

$\begin{array}{llllllllll}1000 & -. & .050 & .57 & .055 & .28 & .91 & 12.5 & 3.6 & 33 \\ 1300 & 1210 & .042 & .53 & .053 & .31 & .89 & 15.5 & 7.7 & 76 \\ 1635 & 1350 & .000 & .48 & .055 & .22 & .76 & 18 & 8.2 & 96 \\ 0035 & 1150 & .028 & .30 & .080 & .54 & .92 & 16 & 6.7 & 78 \\ 0510 & 1140 & .042 & .50 & .086 & .39 & .98 & 15.5 & 3.3 & 33 \\ 0840 & 1230 & .042 & .42 & .000 & .47 & .89 & \frac{15.5}{16} & \frac{6.8}{6.2} & \frac{77}{66} \\ \text { Avg } & \frac{.060}{1200} & .034 & .47 & .066 & .37 & .89 & & & \end{array}$


Concentratiul:s of nutrients in ffillsboro Canal

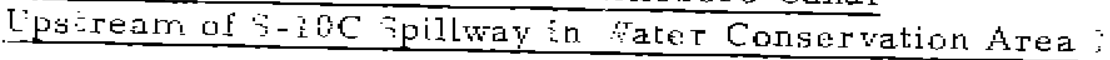

\begin{tabular}{|c|c|c|c|c|c|c|c|c|c|}
\hline Time & Depth & & & Percent & \multicolumn{5}{|c|}{$\operatorname{Tng} / 1$} \\
\hline EDST & metres & $\begin{array}{c}\mathrm{C}^{\circ} \\
\end{array}$ & $\begin{array}{c}\text { Spectific } \\
\text { Cond. }\end{array}$ & $\begin{array}{l}\text { Satura- } \\
\text { tion DO }\end{array}$ & DO & $\begin{array}{l}\mathrm{PO}_{4} \\
\text { as P }\end{array}$ & $\begin{array}{l}\mathrm{NH}_{3} \\
\text { as } \mathrm{N}\end{array}$ & $\begin{array}{l}\mathrm{NO}_{2} \\
\text { as } \mathrm{N}\end{array}$ & $\begin{array}{l}\mathrm{NO}_{3} \\
\text { as } \mathrm{N}\end{array}$ \\
\hline
\end{tabular}

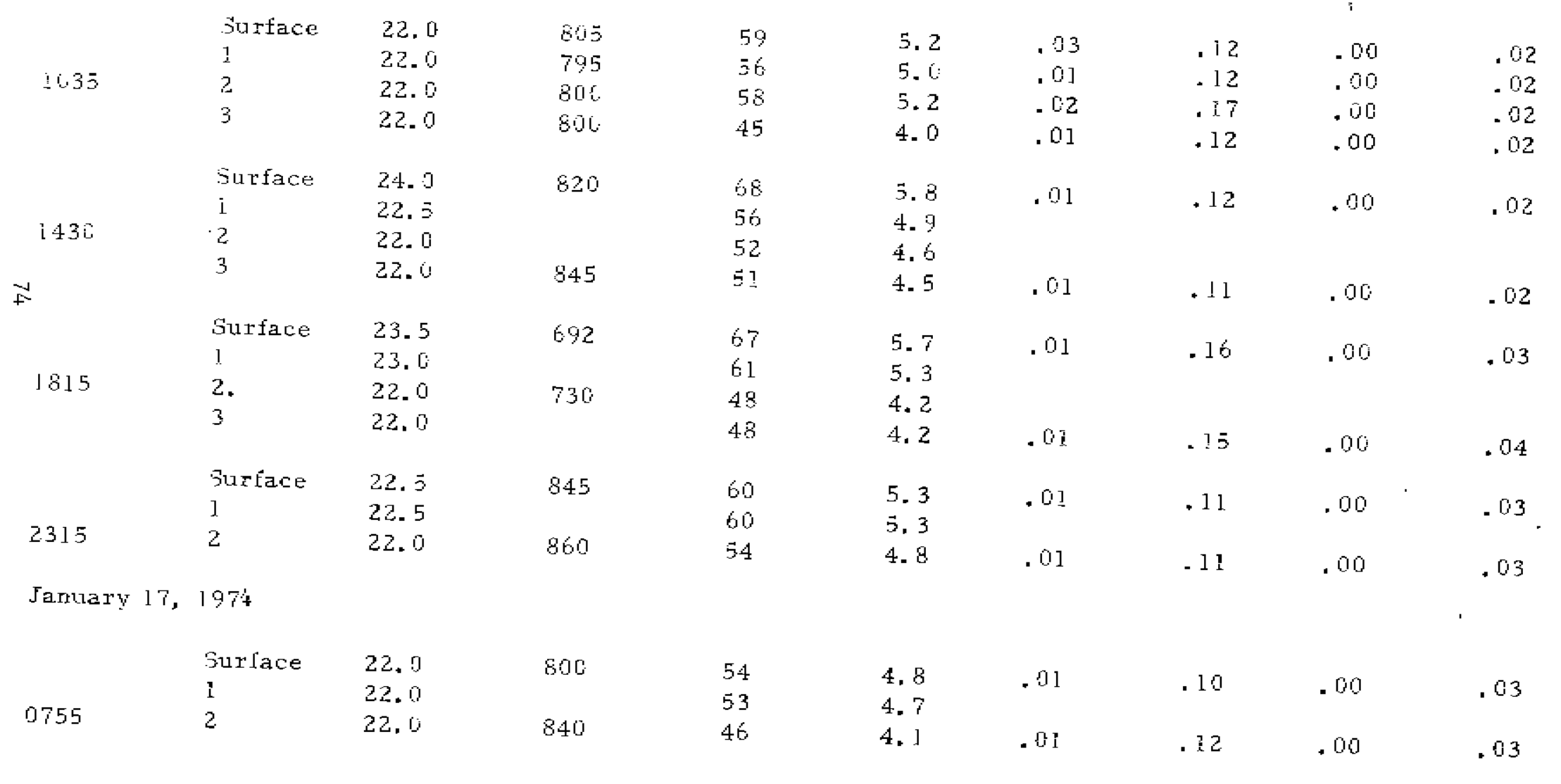


Concentrations of nutrients ir the Iiillsboro Canal

Upstream of S-10D Spillway in Water Conservation Area 1

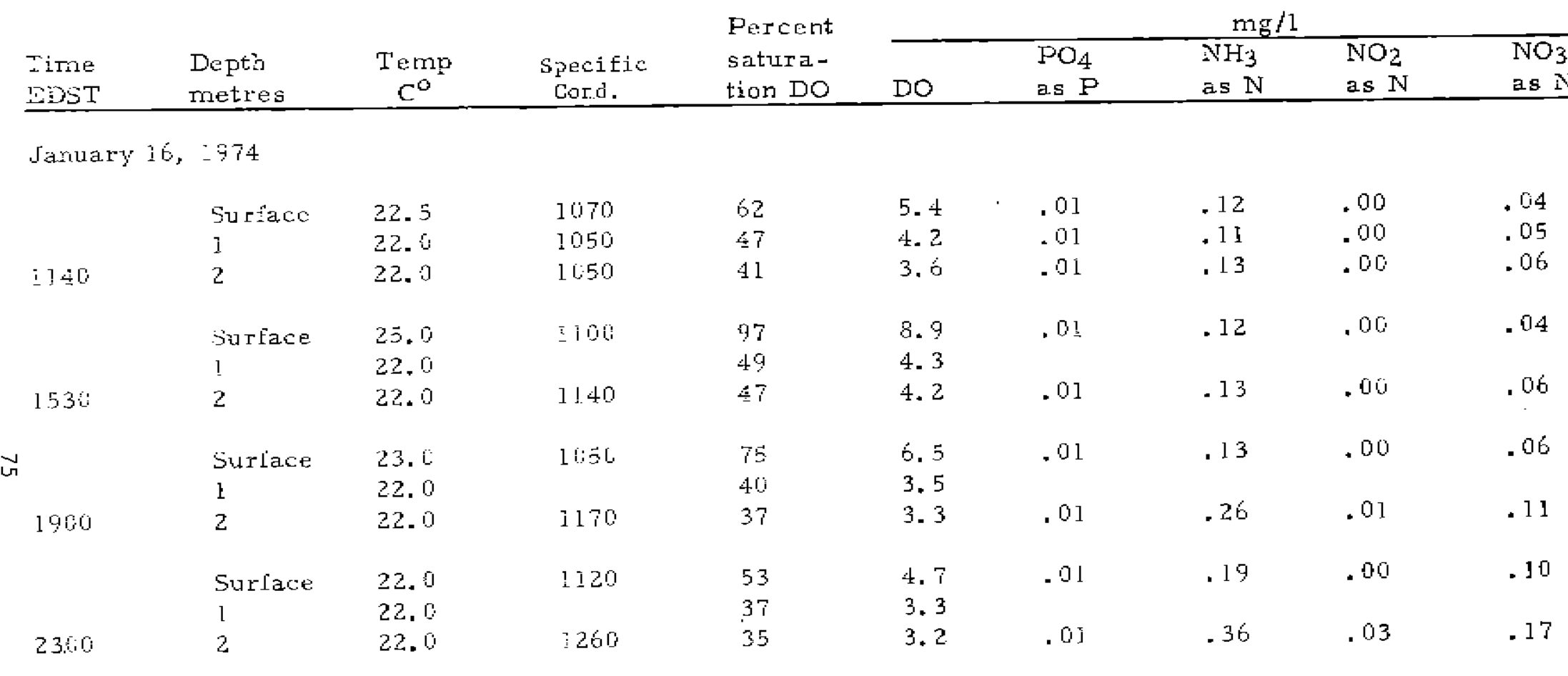

January 17,1974

\begin{tabular}{|c|c|c|c|c|c|c|c|c|c|}
\hline & Surface & $2 \vdots .3$ & $\mathrm{j} 34 \mathrm{C}$ & $2 \overline{8}$ & 2.5 & .01 & .45 & .04 & .27 \\
\hline & 1 & 21.5 & & 25 & 2.3 & & & & \\
\hline $81 \mathrm{i}$ & 2 & 21.5 & $134 \mathrm{C}$ & 25 & 2. 3 & .01 & .38 & .05 & .23 \\
\hline
\end{tabular}


BASIC DATA C

Dicl study at 3 sampling sites in the Hillsboro Canal, at one canal location just sotth of $\mathrm{S}-10 \mathrm{C}$ and in the nearby marshes of Conscrvation Area 2A on January 16-17, 1974. 
Concentrations of nutrients ir Fillsboro Canal

Lstrean of s-ioA Spillway in wiater Conservation Area 1

\begin{tabular}{|c|c|c|c|c|c|c|c|c|c|}
\hline \multirow[b]{2}{*}{$\begin{array}{l}\text { Time } \\
\text { IDST }\end{array}$} & \multirow[b]{2}{*}{$\begin{array}{l}\text { Depth } \\
\text { metres }\end{array}$} & \multirow[b]{2}{*}{$\begin{array}{c}\text { Temp } \\
\mathrm{C}^{0}\end{array}$} & \multirow{2}{*}{$\begin{array}{l}\text { Specific } \\
\text { Cond. } \\
\text { micronhos/cr. } \\
\text { at } 25^{\lrcorner} \mathrm{C}\end{array}$} & \multirow{2}{*}{$\begin{array}{l}\text { Percent } \\
\text { satura- } \\
\text { tion DO }\end{array}$} & \multicolumn{5}{|c|}{$\mathrm{mg} / 1$} \\
\hline & & & & & $\mathrm{DO}$ & $\begin{array}{l}\mathrm{PO}_{4} \\
\text { as } \mathrm{P}\end{array}$ & $\begin{array}{l}\mathrm{NH}_{3} \\
\text { as N }\end{array}$ & $\begin{array}{l}\mathrm{NO}_{2} \\
\text { as } \mathrm{N}\end{array}$ & $\begin{array}{l}\mathrm{NO}_{3} \\
25 \mathrm{~N}\end{array}$ \\
\hline
\end{tabular}

January $16, \quad-974$

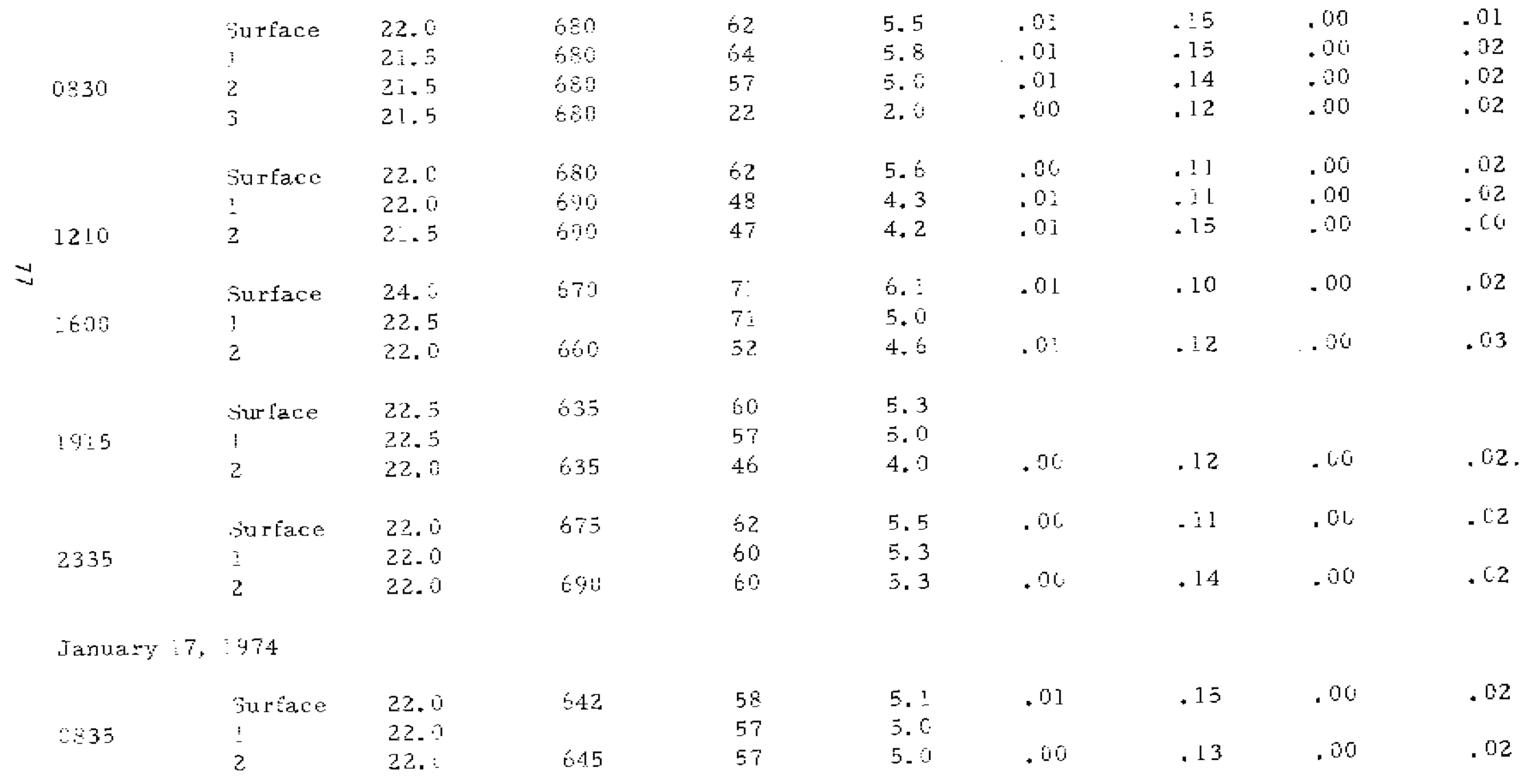


Concentrations of nutrients in a canal and nearby marshes of Area 2 just south of $\mathrm{L}-39$ near $\mathrm{S}-10 \mathrm{C}$ on January 16-17, 1974

\begin{tabular}{|c|c|c|c|c|c|c|c|c|c|c|}
\hline $\begin{array}{l}\text { Location } \\
\text { approx. } \\
\text { (in metres) }\end{array}$ & $\begin{array}{l}\text { Dist. } \\
\text { south of } \\
\text { canal } \\
\end{array}$ & Tinne & Iemp & $\begin{array}{l}\text { Specific } \\
\text { Cond. }\end{array}$ & $\begin{array}{l}\text { Percent } \\
\text { satura- } \\
\text { tion } \mathrm{DO}\end{array}$ & $\mathrm{DO}$ & $\begin{array}{l}\mathrm{PO}_{4} \\
\text { as P }\end{array}$ & $\begin{array}{l}\mathrm{NO}_{3} \\
\text { as } \mathrm{N} \\
\end{array}$ & $\begin{array}{l}\mathrm{NO}_{2} \\
\mathrm{a}=\mathrm{N}\end{array}$ & $\begin{array}{l}\mathrm{NH}_{4} \\
\text { as } 2 \mathrm{~N}\end{array}$ \\
\hline \multirow[t]{7}{*}{ Cana } & $16 \operatorname{Tan}$ & 1005 & 22 & 1,430 & 19 & 1.7 & .02 & .07 & .03 & .91 \\
\hline & & 1400 & 26 & 1,460 & 43 & 1.7 & .01 & . l. l & .03 & .96 \\
\hline & & 1705 & 24 & 1,550 & 47 & 4.0 & .01 & .11 & .04 & .90 \\
\hline & & 2000 & 23.5 & 1,450 & 44 & 3.8 & .01 & .11 & .05 & .88 \\
\hline & & 2255 & 23 & 1,380 & 35 & 3.1 & & & & \\
\hline & $17 \mathrm{Jan}$ & 0615 & 22.2 & 1,418 & 9 & 1.4 & .02 & .10 & .05 & .82 \\
\hline & & 0800 & 22.0 & ], 400 & 10 & 1.5 & .01 & .10 & .04 & .94 \\
\hline \multirow{7}{*}{$\begin{array}{ll}15 \text { m: in } \\
\text { Marsh } \\
\text { W }\end{array}$} & $16 \mathrm{Jan}$ & 1010 & 21.5 & 2,250 & 12 & 1.1 & .01 & .00 & .00 & .24 \\
\hline & & 1405 & 25.2 & 2,290 & 48 & 4.0 & .01 & .00 & .00 & .32 \\
\hline & & 1710 & 26 & 2,380 & 65 & 5.4 & .01 & .00 & .00 & .32 \\
\hline & & 2005 & 24 & 2,340 & 44 & 3.8 & .01 & .00 & .00 & .37 \\
\hline & & 2300 & 23 & 2,240 & 19 & I. 7 & .01 & .00 & .00 & .57 \\
\hline & $17 \mathrm{Jan}$ & 0620 & 21.8 & 2,330 & 0 & 0.2 & .01 & .00 & .00 & .60 \\
\hline & & 0810 & 21.0 & 2,300 & 3 & 0.4 & .02 & .00 & .00 & .70 \\
\hline \multirow{6}{*}{$\begin{array}{l}30 \pi: \text { in } \\
\text { Marsh }\end{array}$} & $16 \operatorname{Tan}$ & 1015 & 20 & 1,300 & 6 & 0.6 & - & - & - & - \\
\hline & & 1410 & 22 & 1,470 & 20 & 1.9 & $.1 \mathrm{I}$ & .00 & .00 & .66 \\
\hline & & 2010 & 21 & 1,420 & 12 & 1.1 & .08 & .00 & .00 & .52 \\
\hline & & 2305 & 20.3 & 1,380 & 4 & 0.4 & .08 & .00 & .00 & .45 \\
\hline & 17 Jan & 0625 & 19.1 & 1,400 & 4 & 0.4 & .08 & .00 & .00 & .49 \\
\hline & & $08 \mathrm{H} 5$ & 18.8 & 1,420 & 4 & 0.4 & .11 & .00 & .00 & .62 \\
\hline \multirow[t]{5}{*}{$800 \mathrm{~m}$} & $16 \operatorname{Jan}$ & 1050 & 20 & 970 & 30 & 2.7 & .01 & .00 & .00 & .14 \\
\hline & & 1720 & 23 & 1,220 & 55 & 4.8 & .01 & .00 & .00 & .18 \\
\hline & & 2020 & 20 & 1,250 & 9 & 0.9 & .01 & .00 & .00 & .20 \\
\hline & $17 \mathrm{Jan}$ & $\begin{array}{l}2310 \\
0630\end{array}$ & $\begin{array}{l}19 \\
18.5\end{array}$ & $\begin{array}{l}1,140 \\
1,180\end{array}$ & $\begin{array}{l}7 \\
3\end{array}$ & $\begin{array}{l}0.7 \\
0.3\end{array}$ & .02 & .00 & .00 & .18 \\
\hline & & 0820 & 18.2 & 1,780 & 3 & 0.3 & & & & \\
\hline
\end{tabular}


Concentrations of nutrients in a canal and nearby marshes of Area 2 just south of $L-39$ near S-1DC on January $16-17,1974$

\begin{tabular}{|c|c|c|c|c|c|c|c|c|c|c|}
\hline $\begin{array}{l}\text { Location } \\
\text { approx. } \\
\text { (in metres) }\end{array}$ & $\begin{array}{l}\text { Dist. } \\
\text { south of } \\
\text { canal }\end{array}$ & Time & Temp & $\begin{array}{l}\text { Specific } \\
\text { Cond. }\end{array}$ & $\begin{array}{l}\text { Percent } \\
\text { satura- } \\
\text { tion DO }\end{array}$ & DO & $\begin{array}{l}\mathrm{PO}_{4} \\
\text { as P }\end{array}$ & $\begin{array}{l}\mathrm{NO}_{3} \\
\text { as } \mathrm{N}\end{array}$ & $\begin{array}{l}\mathrm{NO}_{2} \\
\text { as } \mathrm{N}\end{array}$ & $\begin{array}{l}\mathrm{NH}_{4} \\
\text { as N }\end{array}$ \\
\hline \multirow[t]{3}{*}{ I $600 \pi$} & & 1105 & 22 & 1,300 & 38 & 3.4 & .01 & .00 & .00 & .24 \\
\hline & & 2025 & 19.8 & 1,220 & 9 & 0.9 & .01 & .00 & .00 & .21 \\
\hline & & 0640 & 18.4 & 1,140 & 4 & 0.4 & $0 !$ & .00 & .00 & .20 \\
\hline
\end{tabular}


BASIC DATA D

Dicl study at 11 sampling sites near pumping station $\mathrm{S}-9$ on January 16-18, 1973. All measurements at approximately 0.3 metres Backpumping began about 9:30 A. M. on January 17 and ended just after 4:00 P.M. on the samed day. Dissolved oxygen (DO), $\mathrm{PO}_{4}-\mathrm{P}, \mathrm{NH}_{3}-\mathrm{N}$, $\mathrm{NO}_{2}-\mathrm{N}, \mathrm{NO}_{3}-\mathrm{N}$ in $\mathrm{mg} / \mathrm{l}$. Specific conductance $(K)$ in micromhos $/ \mathrm{cm}$ at $25^{\circ} \mathrm{C}$. 
Sampling Site I near S-9

\begin{tabular}{|c|c|c|c|c|c|c|c|c|}
\hline \multirow[b]{2}{*}{ Time } & \multirow{2}{*}{$\begin{array}{c}\text { Temp } \\
\mathrm{C}^{\mathrm{O}}\end{array}$} & \multirow[b]{2}{*}{$\begin{array}{l}\text { Specific } \\
\text { cond. }\end{array}$} & \multirow{2}{*}{$\begin{array}{l}\text { Percent } \\
\text { saturation } \\
\text { DO }\end{array}$} & \multicolumn{5}{|c|}{$\mathrm{mg} / 1$} \\
\hline & & & & $\overline{\mathrm{DO}}$ & $\begin{array}{l}\mathrm{PO}_{4-}^{-} \\
\mathrm{P}\end{array}$ & $\begin{array}{l}\mathrm{NH}_{3}- \\
\mathrm{N}\end{array}$ & $\begin{array}{l}\mathrm{NO}_{2}- \\
\mathrm{N}\end{array}$ & $\begin{array}{l}\mathrm{NO}_{3}- \\
\mathrm{N}\end{array}$ \\
\hline
\end{tabular}

January 16, 1973

0930

1200

1500

1820

2200

27.0

23.0

23.0

22. 0

January I 7, 1973

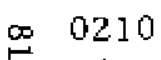

0620

0925

0955

1055

1150

1330

1440

1600

1805

2225

22.0
20.0
22.0
22.0
21.0
21.0
20.5
21.0
21.0
21.5
22.0

Jamuary 18, 1973

$\begin{array}{lll}0225 & 21.5 & 750 \\ 0630 & 22.0 & 710 \\ 1015 & 21.0 & 760\end{array}$

0630

21.0

760

$\begin{array}{rrrrrr} & 2.0 & .031 & 0.54 & .018 & .04 \\ 13 & 2.1 & & & & \\ 4 & 1.7 & .035 & 0.56 & .025 & .02 \\ 4 & 0.4 & .000 & 0.53 & .025 & .00 \\ & 0.4 & .000 & 0.57 & .020 & .00\end{array}$

$\begin{array}{rr}695 & 3 \\ 710 & 6 \\ & 18 \\ & 18 \\ & 17 \\ 760 & 17 \\ 770 & 13 \\ & 13 \\ 810 & 19 \\ 800 & 1 \\ & 5\end{array}$

$\begin{array}{ll}0.3 & .000 \\ 0.6 & .000 \\ 1.6 & .000 \\ 1.7 & .000 \\ 1.6 & .000 \\ 1.7 & .000 \\ 1.3 & .000 \\ 1.3 & .000 \\ 1.8 & .000 \\ 0.1 & .000 \\ 0.5 & .000\end{array}$

0.55

0.56

0.58

0.53

0.49

0.47

0.47

0.46

0.48

0.48

0.53

.013
.013
.006
.000
.000
.000
.005
.000
.002
.000
.006

.00

.00

.00

.00

.00

.00

.02

.05

.05

.00

.01

$\begin{array}{ll}0.5 & .000 \\ 0.5 & .000 \\ 1.4 & .000\end{array}$

0.53

0.54

0.47
.016
.012
.005

.00

15

0.5
1.4

.00

.00 
Sampling Site 2 near S-9

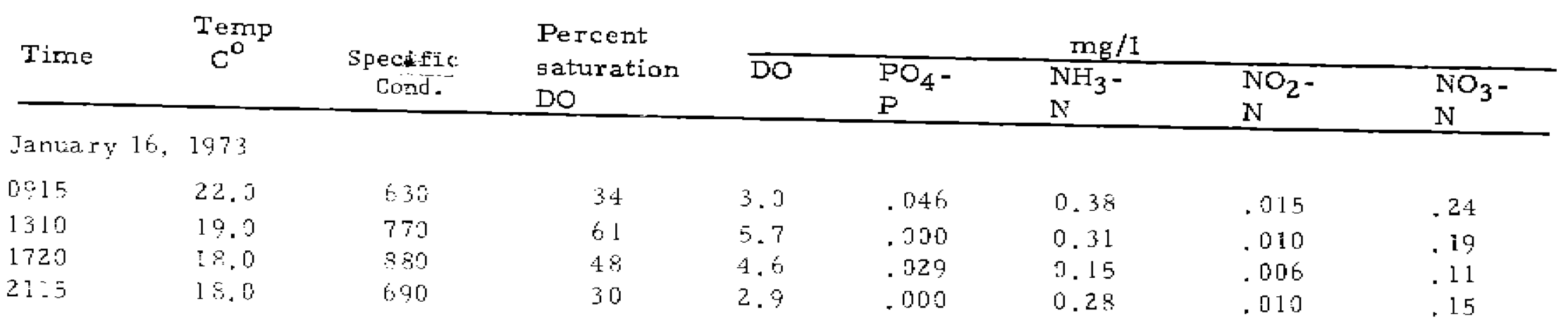

January 17, 1973

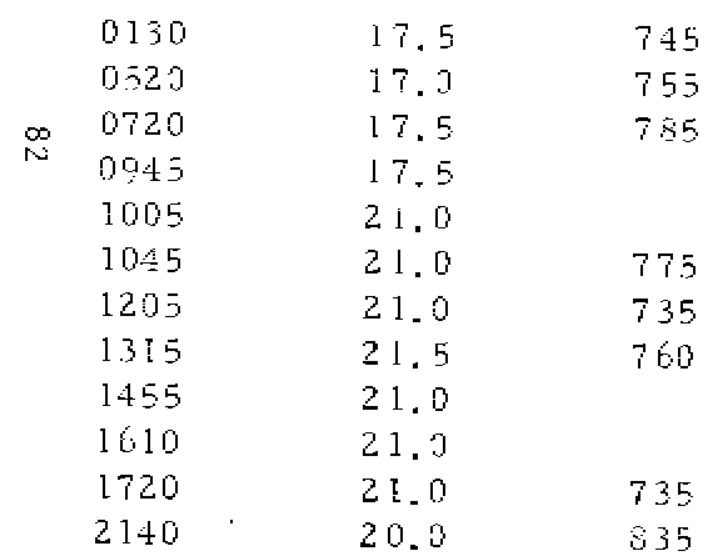

Janua $=y 18,1973$

$\begin{array}{lll}014 J & 20.9 & 740 \\ 0525 & 20.9 & 735 \\ 0930 & 22.0 & 745\end{array}$

$\begin{array}{rll}34 & 3.3 & .000 \\ 38 & 3.8 & .000 \\ 35 & 3.4 & .000 \\ 60 & 5.8 & \\ 19 & 1.8 & .000 \\ 25 & 1.9 & .000 \\ 29 & 1.9 & .000 \\ 14 & 1.3 & .000 \\ 3 & 0.8 & .000 \\ 24 & 2.2 & .000 \\ 8 & 9.5 & .000 \\ 16 & 1.5 & .000\end{array}$

0.29
0.29
0.27
0.42
0.46
0.49
0.44
0.45
0.48
0.42
0.41

.912

.15

55

35

60

835

.000

.500

.15

.15
.15

03

.011

.00

.004

.906

.00

010

.04

000

.000

.05

.000

.05

.04

.002

.05

$\begin{array}{rll}11 & 1.0 & .000 \\ 11 & 1.9 & .000 \\ 9 & 0.9 & .000\end{array}$

0.54
0.40
0.50

.003

.002

.012

.04
.00 
Sampling Site 3 near S-9

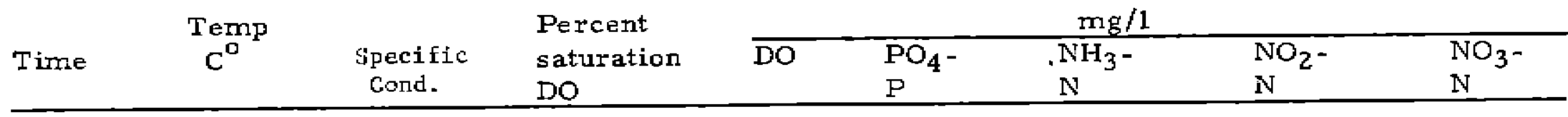

January 16, 1973

$\begin{array}{rrrrrrrrr}0935 & 17.0 & 680 & 93 & 9.1 & .000 & .02 & .000 & .00 \\ 1320 & 17.0 & 760 & 98 & 9.7 & .000 & .03 & .000 & .00 \\ 1730 & 17.0 & 780 & 105 & 10.3 & .000 & .01 & .000 & .00 \\ 2126 & 16.0 & 710 & 103 & 10.2 & .000 & .02 & .000 & .00\end{array}$

January 17, 1973

$\begin{array}{rrrrrrrrr}0128 & 15.5 & 750 & 101 & 10.2 & .000 & .02 & .000 \\ 0 & 1525 & 15.0 & 730 & 78 & 8.0 & .000 & .02 & .000 \\ 0925 & 16.0 & 730 & 87 & 3.7 & .000 & .02 & .000 \\ 1320 & 19.0 & 745 & 103 & 9.7 & .000 & .01 & .000 \\ 1730 & 19.5 & 690 & 117 & 10.8 & .000 & .02 & .00 \\ 2145 & 18.5 & 820 & 108 & 10.2 & .000 & .02 & .000 & .000\end{array}$

January 18, 1973

$\begin{array}{lllllllll}0145 & 17.5 & 725 & 87 & 8.4 & .000 & .02 & .000 & .00 \\ 0535 & 17.5 & 725 & 87 & 8.4 & .000 & .01 & .000 & .00 \\ 0935 & 18.0 & 765 & 70 & 6.7 & .000 & .02 & .000 & .00\end{array}$


Sampling Site 4 near S-9

\begin{tabular}{|c|c|c|c|c|c|c|c|c|}
\hline \multirow[b]{2}{*}{ Time } & \multirow{2}{*}{$\mathrm{C}^{\text {Temp }}$} & \multirow{2}{*}{$\begin{array}{l}\text { Specific } \\
\text { Gond. }\end{array}$} & Percent & \multicolumn{5}{|c|}{$\mathrm{mg} / \mathrm{l}$} \\
\hline & & & $\begin{array}{l}\text { saturation } \\
\text { DO }\end{array}$ & $\overline{\mathrm{DO}}$ & $\begin{array}{l}\mathrm{PO}_{4}- \\
\mathrm{P}\end{array}$ & $\begin{array}{l}\mathrm{NH}_{3}- \\
\mathrm{N}\end{array}$ & $\mathrm{NO}_{2}-$ & $\begin{array}{l}\mathrm{NO}_{3}- \\
\mathrm{N}\end{array}$ \\
\hline
\end{tabular}

January 16, 1973

\begin{tabular}{|c|c|c|c|c|c|c|c|c|}
\hline 1100 & 18.5 & 709 & 87 & 8.2 & .000 & -05 & .000 & .00 \\
\hline 1445 & 15.0 & 800 & 68 & 7.0 & .000 & .06 & .000 & .00 \\
\hline 1815 & 14.0 & 760 & 28 & 3.0 & .000 & .04 & .000 & .00 \\
\hline 2150 & 15.0 & 725 & 20 & 2.1 & .000 & .11 & -000 & .00 \\
\hline
\end{tabular}

January 17,1973

$\begin{array}{ll}0200 & 15 . \\ 0605 & 15 . \\ 0955 & 15 . \\ \mathbf{1 4 0 0} & 17 . \\ 1755 & 17 . \\ 2215 & 16 . \\ & \\ \text { January 18, } 1973\end{array}$

$\begin{array}{lllllllll}0215 & 16.5 & 690 & 16 & 1.6 & .000 & .15 & .000 & .00 \\ 0615 & 16.0 & 740 & 10 & 1.0 & .000 & .17 & .000 & .00 \\ 1003 & 17.0 & 755 & 16 & 1.6 & .000 & .16 & .000 & .02\end{array}$


Sampling Site 5 near $5-9$

\begin{tabular}{|c|c|c|c|c|c|c|c|c|}
\hline \multirow[b]{2}{*}{ Time } & \multirow{2}{*}{$\underset{\mathrm{C}^{\circ}}{\text { Temp }}$} & \multirow{2}{*}{$\begin{array}{l}\text { Specific } \\
\text { Cond. }\end{array}$} & \multirow{2}{*}{$\begin{array}{l}\text { Percent } \\
\text { saturation } \\
\text { DO }\end{array}$} & \multicolumn{4}{|c|}{$\operatorname{mig} / 1$} & \\
\hline & & & & $\overline{\mathrm{DO}}$ & $\begin{array}{l}\mathrm{PO}_{4}- \\
\mathrm{P}\end{array}$ & $\begin{array}{l}\mathrm{NH}_{3}- \\
\mathrm{N}\end{array}$ & $\begin{array}{l}\mathrm{NO}_{2}- \\
\mathrm{N}\end{array}$ & $\begin{array}{l}\mathrm{NO}_{3}- \\
\mathrm{N}\end{array}$ \\
\hline
\end{tabular}

January 16, 1973

$\begin{array}{lllllllll}0945 & 19.5 & 370 & 73 & 6.8 & .000 & 0.50 & .000 & .22 \\ 1335 & 16.0 & 960 & 73 & 7.3 & .000 & 0.10 & .002 & .12 \\ 1735 & 17.0 & 930 & 63 & 6.1 & .029 & 0.12 & .000 & .11 \\ 2125 & 17.0 & 870 & 60 & 5.9 & .000 & 0.12 & .002 & .11\end{array}$

Jantary 17,1973

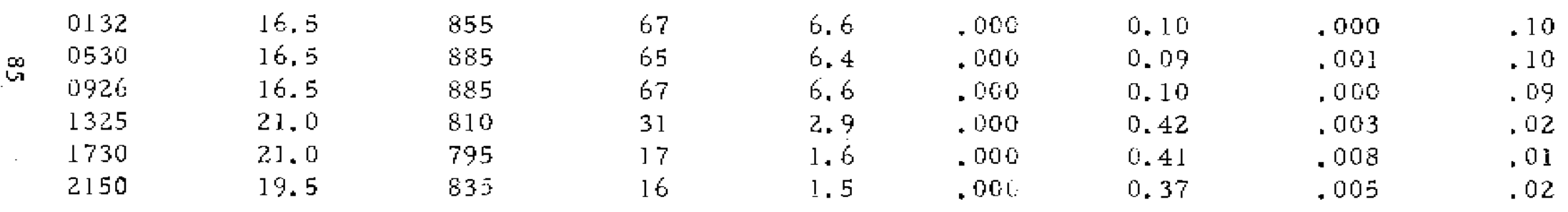

January 18, 1973

$\begin{array}{lllllllll}0148 & 19.5 & 770 & 19 & 1.8 & .000 & 0.35 & .005 & .02 \\ 0535 & 18.5 & 800 & 19 & 1.9 & .000 & 0.27 & .006 & .03 \\ 0936 & 18.0 & 820 & 40 & 3.9 & .000 & 0.22 & .000 & .05\end{array}$


Sampling Site 6 near S-9

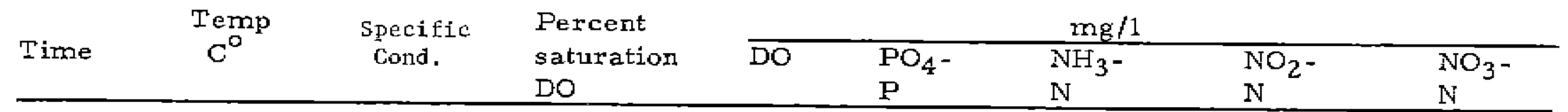

January 16, 1973

\begin{tabular}{|c|c|c|c|c|c|c|c|c|}
\hline 0955 & 19.0 & 829 & 88 & 8.3 & .000 & 0.11 & .000 & 0.11 \\
\hline 1340 & 16.0 & 940 & 84 & 8.4 & .000 & 0.12 & .050 & 0.06 \\
\hline 1750 & 17.0 & 910 & 63 & 6.2 & .000 & 0.11 & .000 & .09 \\
\hline 2127 & 17.0 & 870 & 60 & 5.9 & .000 & 0.10 & .000 & .09 \\
\hline
\end{tabular}

January 17,1973

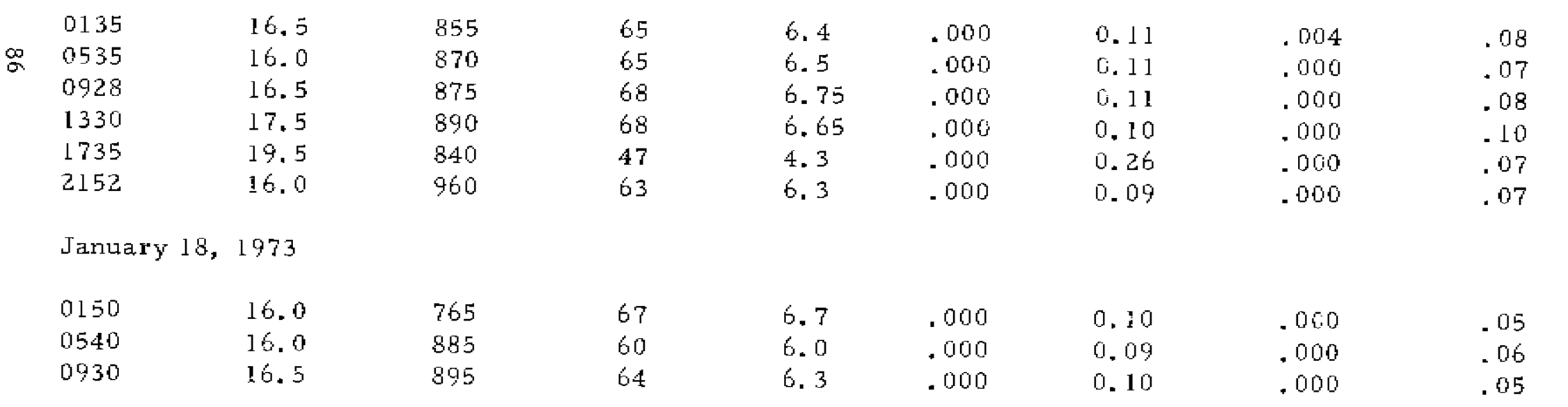


Sampling Site 7 near S -9

\begin{tabular}{|c|c|c|c|c|c|c|c|c|}
\hline \multirow[b]{2}{*}{ Time } & \multirow{2}{*}{$\begin{array}{c}\text { Temp } \\
\mathrm{C}^{\mathrm{O}}\end{array}$} & \multirow{2}{*}{$\begin{array}{l}\text { Specific } \\
\text { Cond. }\end{array}$} & \multirow{2}{*}{$\begin{array}{l}\text { Percent } \\
\text { saturation } \\
\text { DO }\end{array}$} & \multicolumn{5}{|c|}{$\mathrm{mg} / 1$} \\
\hline & & & & DO & $\begin{array}{l}\mathrm{PO}_{4}- \\
\mathrm{P}\end{array}$ & $\begin{array}{l}\mathrm{NH}_{3}- \\
\mathrm{N} \\
\end{array}$ & $\begin{array}{l}\mathrm{NO}_{2}- \\
\mathrm{N}\end{array}$ & $\begin{array}{l}\mathrm{NO}_{3}- \\
\mathrm{N}\end{array}$ \\
\hline
\end{tabular}

January 16, 1973

1050

1435

22.5

642

29

730

19.0

50

1610

16.0

830

2. 6

.025

$4.7 \quad .000$

0.37

0.34

0.30

.000

3.8

.000

.012

.20

40

.070

.17

January 17,1973

0156

的 0600

0952

1357

1750

22 I 3

$$
\begin{aligned}
& 17.0 \\
& 16.0 \\
& 17.0 \\
& 21.0 \\
& 20.5 \\
& 20.0
\end{aligned}
$$

January 18,1973

0210
0610
1000

$$
\begin{aligned}
& 18.5 \\
& 20.0 \\
& 19.0
\end{aligned}
$$

4. 4

$$
\text { 2. } 8
$$

5.8

1.7

2.3

1.6

$$
\begin{aligned}
& .000 \\
& .000 \\
& .000 \\
& .000 \\
& .000 \\
& .000
\end{aligned}
$$

740

765

810

8

33

$\begin{array}{ll}1.4 & .000 \\ 0.8 & .000 \\ 3.2 & .000\end{array}$

.000
0.24
0.10
0.17
0.16
0.45
0.42
0.41

.006

.14

.006

.13

.13

.13

.02

.02
.04

.05

. 000

19.

0.42

0.51

0.27
.002
.004
.000

.05 
Sampling Site 8 nea.r S-9

\begin{tabular}{|c|c|c|c|c|c|c|c|c|}
\hline \multirow[b]{2}{*}{ Time } & \multirow{2}{*}{$\begin{array}{c}\text { Temp } \\
\mathrm{C}^{\mathrm{o}}\end{array}$} & \multirow{2}{*}{$\begin{array}{l}\text { Specific } \\
\text { Cond. }\end{array}$} & \multirow{2}{*}{$\begin{array}{l}\text { Percent } \\
\text { saturation } \\
\text { DO }\end{array}$} & \multicolumn{5}{|c|}{$\mathrm{mg} / 1$} \\
\hline & & & & $\overline{\mathrm{DO}}$ & $\begin{array}{l}\mathrm{PO}_{4}- \\
P\end{array}$ & $\begin{array}{l}\mathrm{NH}_{3}- \\
\mathrm{N}\end{array}$ & $\begin{array}{l}\mathrm{NO}_{2}- \\
\mathrm{N}\end{array}$ & $\begin{array}{l}\mathrm{NO}_{3} \\
\mathrm{~N}\end{array}$ \\
\hline Januar & 1973 & & & & & & & \\
\hline 1010 & 17.0 & 770 & 38 & 3.8 & .000 & .04 & .000 & .04 \\
\hline I 400 & 16.5 & 738 & 72 & 7.1 & .000 & .03 & .000 & .00 \\
\hline 1745 & 17.0 & 810 & 54 & 5.3 & .000 & .03 & .000 & .04 \\
\hline 2130 & 16.0 & 785 & 44 & 4.4 & .000 & .04 & .000 & .04 \\
\hline
\end{tabular}

January ]7, 1973

\begin{tabular}{|c|c|c|c|c|c|c|c|}
\hline 0140 & 15.5 & 785 & 30 & 3.0 & .080 & .06 & .004 \\
\hline 0540 & 15.0 & 800 & 24 & 2.5 & .000 & .04 & .000 \\
\hline 0933 & 17.0 & 805 & 28 & 2.8 & .000 & .05 & .000 \\
\hline 1335 & 18.5 & 835 & 48 & 4.6 & .000 & .05 & .002 \\
\hline 1740 & 18.0 & 815 & 46 & 4.4 & .000 & .04 & .000 \\
\hline 2157 & 17.0 & 880 & 37 & 3.7 & $=000$ & .04 & .000 \\
\hline
\end{tabular}

January 18, 1973

$\begin{array}{lllllllll}0155 & 17.5 & 700 & 43 & 4.2 & .000 & .04 & .000 & .06 \\ 0545 & 16.0 & 815 & 19 & 1.9 & .000 & .05 & .000 & .05 \\ 0945 & 17.5 & 830 & 36 & 3.5 & .000 & .05 & .000 & .07\end{array}$


Sampling Site 9 near S-9

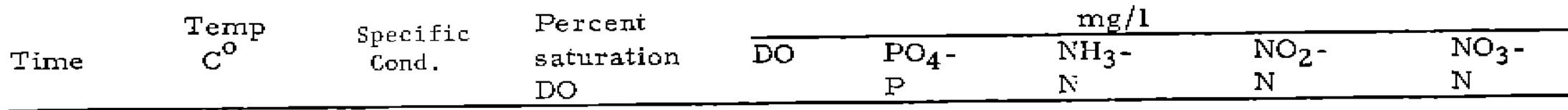

January 16, 1973

\begin{tabular}{|c|c|c|c|c|c|c|c|}
\hline 1020 & 20.0 & 755 & 65 & 6.0 & .000 & .23 & .010 \\
\hline 1410 & 17.5 & 855 & 68 & 6.7 & .000 & .19 & .006 \\
\hline 1750 & 17.5 & 860 & 49 & 4.7 & .000 & .21 & .008 \\
\hline 2135 & 17.5 & 850 & 48 & 4.6 & .000 & .19 & .005 \\
\hline
\end{tabular}

January 17,1973

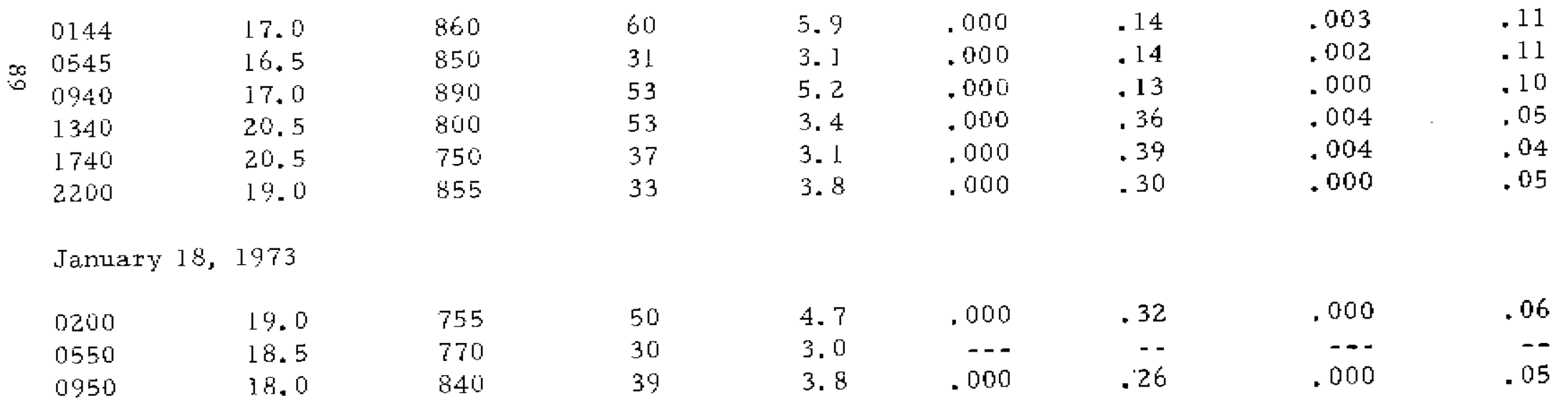


Sampling Site 10 near S-9

\begin{tabular}{|c|c|c|c|c|c|c|c|c|}
\hline \multirow[b]{2}{*}{ Time } & \multirow{2}{*}{$\begin{array}{c}\text { Temp } \\
\mathrm{C}^{\mathrm{O}}\end{array}$} & \multirow{2}{*}{$\begin{array}{l}\text { Specific } \\
\text { Cond. }\end{array}$} & \multirow{2}{*}{$\begin{array}{l}\text { Percent } \\
\text { saturation } \\
\text { DO }\end{array}$} & \multicolumn{5}{|c|}{$\mathrm{mg} / 1$} \\
\hline & & & & $\overline{D O}$ & $\begin{array}{l}\mathrm{PO}_{4-}^{-} \\
P \\
\end{array}$ & $\begin{array}{l}\mathrm{NH}_{3}- \\
\mathrm{N}\end{array}$ & $\begin{array}{l}\mathrm{NO}_{2}- \\
\mathrm{N}\end{array}$ & $\begin{array}{l}\mathrm{NO}_{3}- \\
\mathrm{N}\end{array}$ \\
\hline
\end{tabular}

Janiary 16, 1973

$\begin{array}{lllllllll}1030 & 20.0 & 798 & 63 & 5.8 & .000 & 0.14 & .000 & .15 \\ 1415 & 16.5 & 910 & 68 & 6.8 & & & \\ 1800 & 17.5 & 880 & 53 & 5.1 & .000 & 0.16 & .002 & .14 \\ 2137 & 17.0 & 865 & 54 & 5.3 & .000 & 0.15 & .004\end{array}$

January $17, \quad 1973$

$8 \begin{aligned} & 0146 \\ & 0550 \\ & 0943 \\ & 1345 \\ & 1745 \\ & 2203\end{aligned}$

$\begin{array}{ll}17.0 & 855 \\ 16.5 & 870 \\ 17.0 & 890 \\ 17.5 & 875 \\ 20.0 & 780 \\ 19.0 & 860\end{array}$

64
62
65
64
42
39

$\begin{array}{ll}6.2 & .000 \\ 6.1 & .000 \\ 6.4 & .000 \\ 6.2 & .000 \\ 3.9 & .000 \\ 3.7 & .000\end{array}$

\subsection{4}

0.13

.003

.002

0.12

0. 14

.000

.000

.008

0.33

.002

.12

i. 29

$$
.902
$$$$
\text { . I ! }
$$$$
.10
$$$$
.11
$$$$
.03
$$$$
.05
$$

January 18, 1973

$\begin{array}{lll}0205 & 18.5 & 805 \\ 0600 & 17.5 & 790 \\ 0950 & 18.0 & 850\end{array}$

51
45
53

$\begin{array}{ll}4.7 & .000 \\ 4.4 & .000 \\ 5.1 & .000\end{array}$

0.22
0.21
0.17

.000

.000

.06

45

$\begin{array}{ll}4.4 & .000 \\ 5.1 & .000\end{array}$

.000

.07

.06 
Sampling Site 11 near S-9

\begin{tabular}{|c|c|c|c|c|c|c|c|c|}
\hline \multirow{3}{*}{ Time } & \multirow{3}{*}{$\mathrm{C}^{\mathrm{T}}$} & \multirow{3}{*}{$\begin{array}{l}\text { Specific } \\
\text { Cond. }\end{array}$} & Percent & \multicolumn{5}{|c|}{$\mathrm{mg} / 1$} \\
\hline & & & saturation & $\mathrm{DO}$ & $\mathrm{PO}_{4}^{-}$ & $\mathrm{NH}_{3}-$ & $\mathrm{NO}_{2}-$ & $\mathrm{NO}_{3}-$ \\
\hline & & & DO & & $\mathrm{P}$ & $\mathrm{N}$ & $\mathrm{N}$ & $\mathrm{N}$ \\
\hline
\end{tabular}

January 16, 1973

$\begin{array}{lllllllll}1040 & 20.0 & 780 & 63 & 5.8 & .000 & .17 & .004 & .14 \\ 1425 & 17.0 & 885 & 68 & 6.7 & .000 & .17 & .004 & .15 \\ 1605 & 17.0 & 890 & 51 & 5.0 & .000 & .15 & .004 & .14 \\ 2140 & 17.0 & 865 & 49 & 4.8 & .000 & .16 & .004\end{array}$

January 17, 1973

$\begin{array}{lll}0150 & 17.0 & 855 \\ 0555 & 16.5 & 865 \\ 0946 & 17.5 & 885 \\ 1350 & 17.5 & 870 \\ 1745 & 18.5 & 850 \\ 2207 & 19.0 & 870\end{array}$

$855 \quad 58$

58

$5.7 \quad .000$

.15

.003

.12

865

3.2

.000

. 14

.000

.11

870

65

6.4

.000

.005

.11

$5.3 \quad .000$

.003

.10

61

5.8

.000

.002

.08

870

3. 0

.000

.20

.000

.04

January 18, 1973

$\begin{array}{lll}0205 & 18.0 & 790 \\ 0605 & 17.5 & 825 \\ 0955 & 18.0 & 850\end{array}$

23

47

47

$\begin{array}{ll}2.3 & .000 \\ 4.6 & .000 \\ 4.5 & .000\end{array}$

.24
.18
.16

.002

.05

.000

.07

.07 
BASIC DATA E

Diel study at 7 sampling sites neat S-5A and at 2 sampling points on $\mathrm{J}-28$ on Septembe 10-12, 1973. Pumping into Area 1 occurred from about 1:00 F. M. to 3:00 P.M. on September 10 and from 4:00 P.M. to 6:00 P.M. on September 11. Specific conductance (K) in micromhos $/ \mathrm{cm}$ at $25^{\circ} \mathrm{C}$. Dis solved oxygen (DO) in $\mathrm{mg} / 1$. 
Sampling Sile:, Above Pump Station S 5-A

\begin{tabular}{|c|c|c|c|c|c|c|c|c|c|}
\hline \multirow[b]{2}{*}{$\begin{array}{l}\text { Time } \\
\text { EDST }\end{array}$} & \multirow[b]{2}{*}{$\begin{array}{l}\text { Depth } \\
\text { metres }\end{array}$} & \multirow[b]{2}{*}{$\begin{array}{c}\text { Temp } \\
\mathrm{C}^{0}\end{array}$} & \multirow[b]{2}{*}{$\begin{array}{l}\text { Specific } \\
\text { Gond. }\end{array}$} & \multirow{2}{*}{$\begin{array}{l}\text { Percent } \\
\text { satura- } \\
\text { tion DO }\end{array}$} & \multicolumn{5}{|c|}{$\mathrm{mg} / 1$} \\
\hline & & & & & DO & $\begin{array}{l}\mathrm{PO}_{4} \\
\text { as } \mathrm{P} \\
\end{array}$ & $\begin{array}{l}\mathrm{NH}_{3} \\
\text { as } \mathrm{N} \\
\end{array}$ & $\begin{array}{l}\mathrm{NO}_{2} \\
\text { as N }\end{array}$ & $\begin{array}{l}\mathrm{NO} \\
\mathrm{ag}\end{array}$ \\
\hline \multicolumn{10}{|c|}{ September 10,1973} \\
\hline \multirow{3}{*}{1000} & 0.3 & 29.5 & 540 & 32 & 2.5 & 0.015 & 0.32 & 0.010 & 0.28 \\
\hline & 1.2 & 29.0 & & 28 & 2.2 & & & & \\
\hline & 1.8 & 29.0 & 1400 & 2 & 0.2 & .060 & 1.4 & .090 & .33 \\
\hline \multirow{3}{*}{1230} & 0.3 & 29.8 & 550 & 59 & 3.0 & .015 & .30 & .020 & .28 \\
\hline & $\Xi .2$ & 29.0 & & 28 & 2.2 & & & & \\
\hline & $\therefore 8$ & 28.0 & 630 & 3 & 0. 3 & .022 & .39 & .020 & .30 \\
\hline \multirow{3}{*}{1600} & 0.3 & 30.5 & 450 & 67 & 5.1 & .012 & .13 & .010 & .24 \\
\hline & 1.2 & 30.0 & & 52 & 4.0 & & & & \\
\hline & 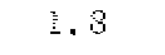 & 29.5 & 940 & 42 & 3.3 & .020 & .80 & .055 & .28 \\
\hline \multirow{3}{*}{1830} & 1.3 & 30.0 & & 53 & 4.2 & .010 & .17 & .000 & .25 \\
\hline & $\therefore .2$ & 29.5 & & 52 & 4.0 & & & & \\
\hline & 3.9 & 29.0 & & 11 & .9 & .025 & 1.1 & .055 & .30 \\
\hline \multirow{3}{*}{2200} & -3 & 29.0 & 480 & 59 & 4.6 & .018 & .22 & .010 & .24 \\
\hline & 1.2 & 29.0 & & 49 & 3.9 & & & & \\
\hline & 1.8 & 29.0 & 940 & 10 & 1.3 & .030 & .82 & .047 & .28 \\
\hline
\end{tabular}

September 11, 1973

\begin{tabular}{|c|c|c|c|c|c|c|c|c|c|}
\hline \multirow{3}{*}{0300} & .3 & 28.0 & 480 & 57 & 4.5 & .016 & .23 & .011 & .24 \\
\hline & 1.2 & 28.0 & & 50 & 4.0 & & & & \\
\hline & 1.9 & 28.0 & 500 & $3 !$ & 2.5 & .015 & .22 & .010 & 2 \\
\hline
\end{tabular}


Sampling Site 1, Above Pump Station S 5-A [cortinued]

\begin{tabular}{|c|c|c|c|c|c|c|c|c|c|}
\hline \multirow{2}{*}{$\begin{array}{l}\text { Iime } \\
\text { EDST }\end{array}$} & \multirow[b]{2}{*}{$\begin{array}{l}\text { Depth } \\
\text { metres }\end{array}$} & \multirow[b]{2}{*}{$\begin{array}{c}\text { Tamp } \\
\mathrm{C}^{\circ}\end{array}$} & \multirow[b]{2}{*}{$\begin{array}{c}\text { Specific } \\
\text { Cond. }\end{array}$} & \multirow{2}{*}{$\begin{array}{l}\text { Percent } \\
\text { satura- } \\
\text { tion DO }\end{array}$} & \multicolumn{5}{|c|}{$\mathrm{mg} / \mathrm{I}$} \\
\hline & & & & & DO & $\begin{array}{l}\mathrm{PO}_{4} \\
\text { as } \mathrm{P} \\
\end{array}$ & $\begin{array}{l}\mathrm{NH}_{3} \\
\text { as } \mathrm{N}\end{array}$ & $\begin{array}{l}\mathrm{NO}_{2} \\
\text { as N }\end{array}$ & $\begin{array}{l}\mathrm{NO}_{3} \\
\text { as } \mathrm{N}\end{array}$ \\
\hline \multicolumn{10}{|c|}{ September JI, 1973 (continued) } \\
\hline \multirow{3}{*}{1150} & .3 & 28.5 & 480 & 40 & 3.2 & .005 & .20 & .005 & .24 \\
\hline & 1.2 & 28.5 & & 37 & 2.9 & & & & \\
\hline & 1.8 & 28.5 & 480 & 32 & 2.6 & .008 & .15 & .1003 & .25 \\
\hline \multirow{3}{*}{1450} & -3 & $3: 0$ & 460 & 57 & 4.3 & .030 & .20 & .000 & .23 \\
\hline & 1.2 & 31.0 & & 54 & 4.2 & & & & \\
\hline & $1+8$ & 31.0 & 460 & 54 & 4. & .010 & .20 & .005 & .24 \\
\hline \multirow{3}{*}{ FอC } & I. 3 & 29.0 & 450 & 65 & 5. & $-[12$ & .15 & .000 & .23 \\
\hline & $\therefore 2$ & 29.0 & & & & & & & \\
\hline & $\stackrel{3}{3} 8$ & 29.0 & $74 \mathrm{C}$ & 54 & 4.3 & .015 & .61 & .025 & .25 \\
\hline \multirow{3}{*}{2130} & $\therefore .3$ & 29.0 & 490 & 65 & 5.0 & .006 & .22 & .000 & .23 \\
\hline & 1.2 & 29.0 & & & & & & & \\
\hline & 1.8 & 29.0 & 595 & 32 & 2.5 & .010 & .42 & .013 & .26 \\
\hline \multicolumn{10}{|c|}{ September 12, 1973} \\
\hline \multirow{3}{*}{0805} & $=3$ & 29.5 & 580 & 45 & 3.5 & .015 & .46 & .006 & .25 \\
\hline & $i .2$ & 29.5 & & & 3.1 & & & & \\
\hline & 1.8 & 29.3 & 540 & 5 & $i .2$ & .015 & .50 & .015 & .27 \\
\hline
\end{tabular}


Sampling Site 2 near S-5A

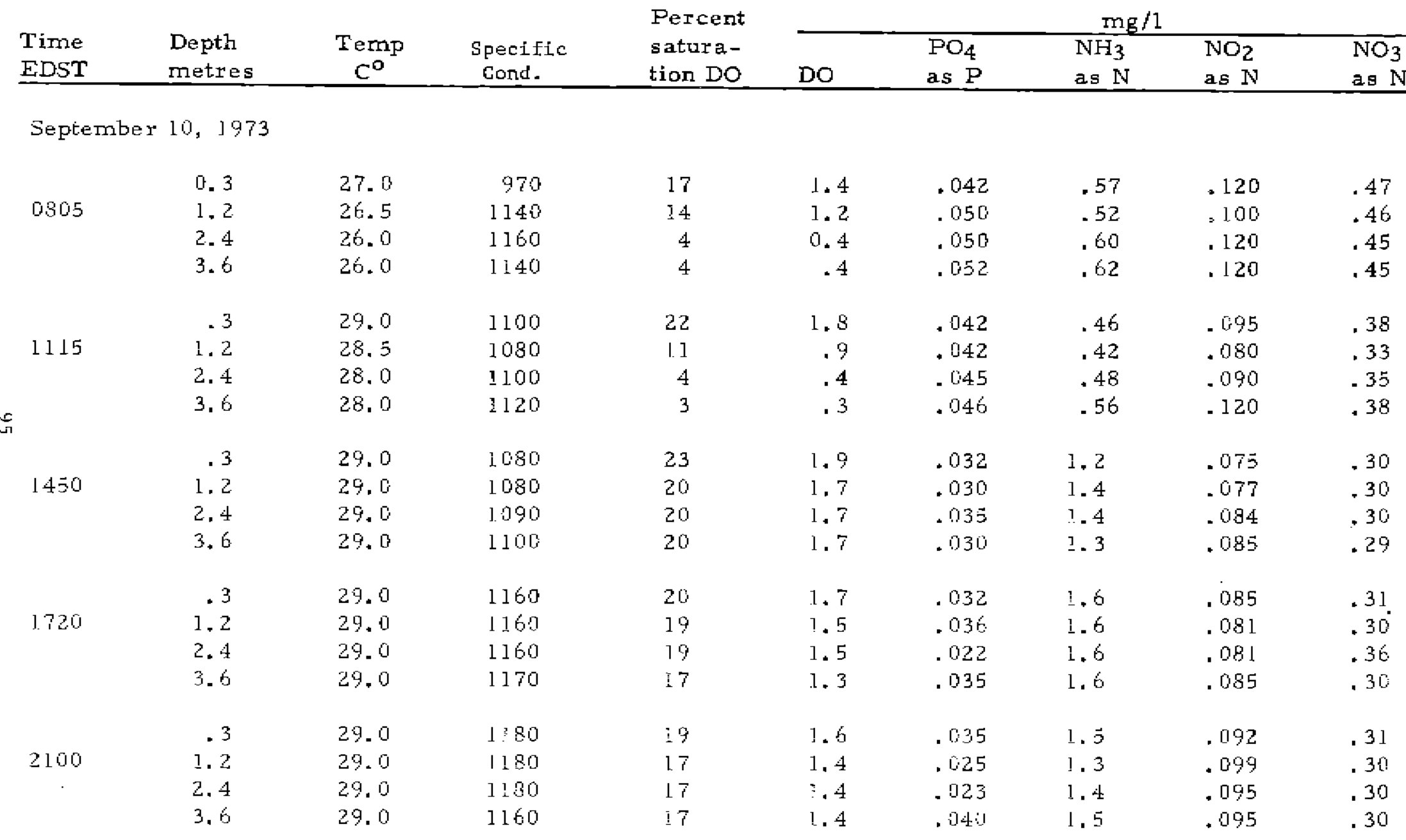


Sampling Site 2 near S-5A (continued)

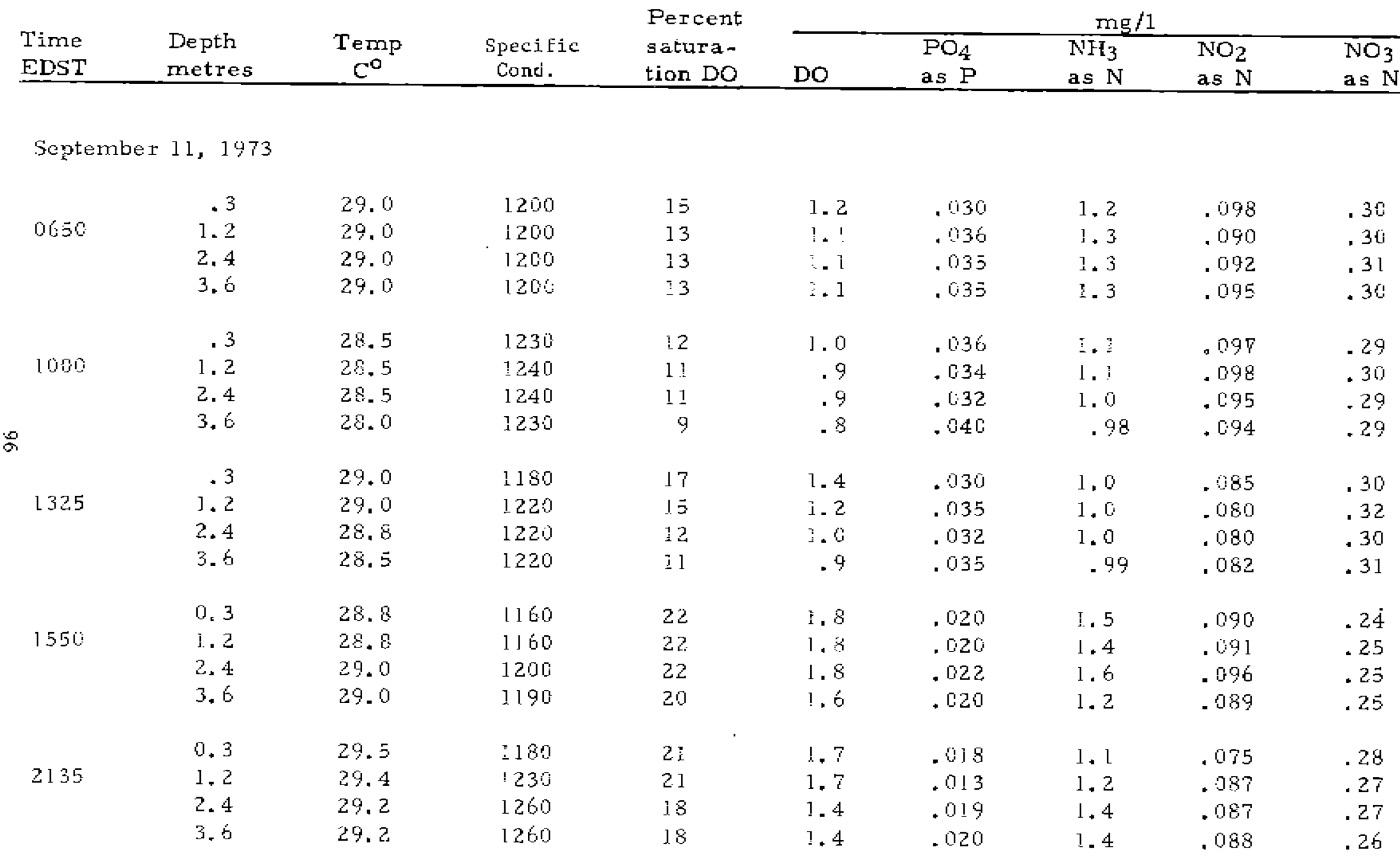


Sampling Site 2 near S-5A (continued)

\begin{tabular}{|c|c|c|c|c|c|c|c|c|c|}
\hline \multirow[b]{2}{*}{$\begin{array}{l}\text { T ime } \\
\text { EDST }\end{array}$} & \multirow[b]{2}{*}{$\begin{array}{l}\text { Depth } \\
\text { metres }\end{array}$} & \multirow[b]{2}{*}{$\begin{array}{c}\text { Temp } \\
\mathrm{C}^{\mathrm{o}} \\
\end{array}$} & \multirow[b]{2}{*}{$\begin{array}{c}\text { Specific } \\
\text { Gond. }\end{array}$} & \multirow{2}{*}{$\begin{array}{l}\text { Percent } \\
\text { satura- } \\
\text { tion Do }\end{array}$} & \multicolumn{5}{|c|}{$\operatorname{mg} / 1$} \\
\hline & & & & & $\mathrm{DO}$ & $\begin{array}{l}\mathrm{PO}_{4} \\
\text { as } \mathrm{P}\end{array}$ & $\begin{array}{l}\mathrm{NH}_{3} \\
\text { as } \mathrm{N}\end{array}$ & $\begin{array}{l}\mathrm{NO}_{2} \\
\text { as } \mathrm{N}\end{array}$ & $\begin{array}{l}\mathrm{NO}_{3} \\
\text { as } \mathrm{N}\end{array}$ \\
\hline \multicolumn{10}{|c|}{ September 12, I 973} \\
\hline \multirow{4}{*}{0645} & 0.3 & 29.8 & 1080 & 26 & 2.0 & .032 & $\therefore .0$ & .070 & .28 \\
\hline & 1.2 & 29.8 & 1080 & 20 & 1.6 & .026 & .90 & .069 & .27 \\
\hline & 2.4 & 29.8 & 1080 & 20 & 1.6 & .016 & .97 & .062 & .30 \\
\hline & 3.6 & 29.8 & 1105 & 11 & 1.4 & .035 & .94 & .070 & .27 \\
\hline
\end{tabular}


Sampling Site 3 rear $\mathrm{S-5A}$

\begin{tabular}{|c|c|c|c|c|c|c|c|c|c|}
\hline \multirow[b]{2}{*}{$\begin{array}{l}\text { Time } \\
\text { EDST } \\
\end{array}$} & \multirow[b]{2}{*}{$\begin{array}{l}\text { Depth } \\
\text { metres }\end{array}$} & \multirow[b]{2}{*}{$\begin{array}{c}\text { Temp } \\
\mathrm{C}^{\mathrm{o}}\end{array}$} & \multirow[b]{2}{*}{$\begin{array}{l}\text { Specitic } \\
\text { Gond. }\end{array}$} & \multirow{2}{*}{$\begin{array}{l}\text { Percent } \\
\text { satura- } \\
\text { tion DO }\end{array}$} & \multicolumn{5}{|c|}{$\mathrm{ng} / 1$} \\
\hline & & & & & $\mathrm{DO}$ & $\begin{array}{l}\mathrm{PO}_{4} \\
\text { as P }\end{array}$ & $\begin{array}{l}\mathrm{NH}_{3} \\
\text { as } \mathrm{N}\end{array}$ & $\begin{array}{l}\mathrm{NO}_{2} \\
\text { as } \mathrm{N} \\
\end{array}$ & $\begin{array}{l}\text { No } \\
\text { as }\end{array}$ \\
\hline \multicolumn{10}{|c|}{ Seplember 10, 1973} \\
\hline \multirow[t]{2}{*}{0900} & $\begin{array}{l}0.3 \\
\therefore .2\end{array}$ & $\begin{array}{l}27.0 \\
26.5\end{array}$ & 1100 & $\begin{array}{l}1.7 \\
13\end{array}$ & $\begin{array}{l}1.4 \\
1.1\end{array}$ & 0.050 & 0.53 & 0.100 & 0.44 \\
\hline & 2.4 & 26.5 & $1 ! 20$ & 3 & 0.3 & .050 & .62 & .110 & .45 \\
\hline \multirow[t]{2}{*}{1200} & $\begin{array}{l}0.3 \\
1.2\end{array}$ & $\begin{array}{l}30.0 \\
28.5\end{array}$ & 1060 & $\begin{array}{l}33 \\
: 3\end{array}$ & $\begin{array}{l}2.6 \\
1.1\end{array}$ & .091 & .43 & .100 & .41 \\
\hline & 2.4 & 28.0 & 1080 & 2 & .2 & .049 & .57 & .100 & .41 \\
\hline \multirow[t]{3}{*}{$16: 0$} & $\begin{array}{l}0.3 \\
1.2 \\
2.4\end{array}$ & $\begin{array}{l}30.0 \\
29.5\end{array}$ & 1220 & $\begin{array}{l}25 \\
20\end{array}$ & $\begin{array}{l}1.9 \\
\therefore .6\end{array}$ & .035 & ?. 4 & .082 & .31 \\
\hline & 3.0 & 29.5 & 1170 & 18 & 1.4 & .032 & 1.3 & .081 & .32 \\
\hline & & 29.5 & & 18 & 1.4 & & & & \\
\hline \multirow{4}{*}{$18 L 5$} & $\begin{array}{l}0.3 \\
1.2\end{array}$ & 29.6 & 240 & 24 & 1.9 & .032 & 1.3 & .081 & .32 \\
\hline & $\begin{array}{l}1.2 \\
2.4\end{array}$ & 29.0 & & 19 & 1.5 & & & & \\
\hline & 3.1 & 29.0 & 1240 & 14 & $: .2$ & .032 & i. 5 & .081 & .31 \\
\hline & 3.2 & 29.0 & & 4 & 1.2 & & & & \\
\hline \multirow{3}{*}{2150} & 0.3 & 29.0 & $\because 220$ & 20 & $! .6$ & .030 & 1.2 & .085 & .28 \\
\hline & $\begin{array}{l}1.2 \\
2.4\end{array}$ & $\begin{array}{l}29.0 \\
29.0\end{array}$ & & 5 & 1.5 & & & & \\
\hline & 3.0 & $\begin{array}{l}29.0 \\
29.0\end{array}$ & 1220 & 18 & 1.4 & .030 & $\therefore 2$ & .985 & .28 \\
\hline
\end{tabular}


Sampling Site 3 near S-5A (continuec)

\begin{tabular}{|c|c|c|c|c|c|c|c|c|c|}
\hline $\begin{array}{l}\text { Time } \\
\text { EDST }\end{array}$ & $\begin{array}{l}\text { Depth } \\
\text { metres }\end{array}$ & $\begin{array}{c}\text { Temp } \\
\mathrm{C}^{\circ}\end{array}$ & $\begin{array}{l}\text { Speci ic } \\
\text { cond. }\end{array}$ & $\begin{array}{l}\text { Percent } \\
\text { satura- } \\
\text { tion DO }\end{array}$ & \multicolumn{5}{|c|}{$\mathrm{mg} / \mathrm{t}$} \\
\hline 0635 & $\begin{array}{l}0.3 \\
1.2 \\
2.4 \\
3.0\end{array}$ & $\begin{array}{l}29.0 \\
29.0 \\
29.0 \\
29.0\end{array}$ & 1160 & $\begin{array}{l}21 \\
17 \\
16 \\
16\end{array}$ & $\begin{array}{l}1.7 \\
1.4 \\
1.3 \\
1.3\end{array}$ & $\begin{array}{l}.030 \\
.036\end{array}$ & 1.3 & $\begin{array}{r}.095 \\
.080\end{array}$ & $\begin{array}{l}.27 \\
.28\end{array}$ \\
\hline 1050 & $\begin{array}{l}0.3 \\
1.2 \\
2.4 \\
3.0\end{array}$ & $\begin{array}{l}28.5 \\
28.5 \\
28.0 \\
29.0\end{array}$ & 1210 & $\begin{array}{l}20 \\
14 \\
10 \\
10\end{array}$ & $\begin{array}{l}1.6 \\
3.2 \\
0.9 \\
0.9\end{array}$ & $\begin{array}{l}.030 \\
.026\end{array}$ & 1.1 & $\begin{array}{l}.094 \\
.095\end{array}$ & $\begin{array}{l}.27 \\
.27\end{array}$ \\
\hline 525 & $\begin{array}{l}0.3 \\
1.2 \\
2.4 \\
3.0\end{array}$ & $\begin{array}{l}29.0 \\
29.4 \\
29.0 \\
29.0\end{array}$ & $\begin{array}{l}1240 \\
1240\end{array}$ & $\begin{array}{l}26 \\
22 \\
26 \\
14\end{array}$ & $\begin{array}{l}2 . . \\
1.8 \\
1.6 \\
1.2\end{array}$ & $\begin{array}{l}.035 \\
.039\end{array}$ & 1.1 & $\begin{array}{l}.082 \\
.090\end{array}$ & $\begin{array}{l}.28 \\
.28\end{array}$ \\
\hline$: 650$ & $\begin{array}{l}0.3 \\
1.2 \\
2.4 \\
3.0\end{array}$ & $\begin{array}{l}29.8 \\
29.8 \\
29.8 \\
29.6\end{array}$ & $\begin{array}{r}960 \\
\vdots 105\end{array}$ & $\begin{array}{l}35 \\
32 \\
28 \\
27\end{array}$ & $\begin{array}{l}2.7 \\
2.5 \\
2.2 \\
2.1\end{array}$ & $\begin{array}{r}.022 \\
.018\end{array}$ & $\begin{array}{l}.95 \\
1.0\end{array}$ & $\begin{array}{l}.060 \\
.065\end{array}$ & $\begin{array}{l}.28 \\
.28\end{array}$ \\
\hline 2215 & $\begin{array}{l}0.3 \\
-.2 \\
2.4 \\
3.0\end{array}$ & $\begin{array}{l}29.0 \\
29.0 \\
29.0 \\
29.0\end{array}$ & $\begin{array}{l}1260 \\
1260\end{array}$ & $\begin{array}{l}18 \\
15 \\
15 \\
15\end{array}$ & $\begin{array}{l}1.4 \\
1.3 \\
1.3 \\
1.3\end{array}$ & $\begin{array}{r}.020 \\
.016\end{array}$ & $\begin{array}{l}1.3 \\
1.3\end{array}$ & $\begin{array}{r}.088 \\
.088\end{array}$ & $\begin{array}{l}.27 \\
.27\end{array}$ \\
\hline
\end{tabular}


Sampling Site 3 near S-5A (continued)

\begin{tabular}{|c|c|c|c|c|c|c|c|c|c|}
\hline \multirow[b]{2}{*}{$\begin{array}{l}\text { Time } \\
\text { EDST }\end{array}$} & \multirow[b]{2}{*}{$\begin{array}{l}\text { Depth } \\
\text { metres }\end{array}$} & \multirow[b]{2}{*}{$\begin{array}{c}\text { Temp } \\
\mathrm{C}^{\circ}\end{array}$} & \multirow[b]{2}{*}{$\begin{array}{c}\text { Specific } \\
\text { Cond. }\end{array}$} & \multirow{2}{*}{$\begin{array}{l}\text { Percent } \\
\text { satura- } \\
\text { tion DO }\end{array}$} & \multicolumn{5}{|c|}{$\mathrm{mg} / 1$} \\
\hline & & & & & DO & $\begin{array}{l}\mathrm{PO}_{4} \\
\text { as } \mathrm{P} \\
\end{array}$ & $\begin{array}{l}\mathrm{NH}_{3} \\
\text { as } \mathrm{N} \\
\end{array}$ & $\begin{array}{l}\mathrm{NO}_{2} \\
\text { as } \mathrm{N} \\
\end{array}$ & $\begin{array}{l}\mathrm{NO} \\
\text { as: }\end{array}$ \\
\hline \multicolumn{10}{|c|}{ September 12,1973} \\
\hline 0745 & $\begin{array}{l}0.3 \\
1.2\end{array}$ & $\begin{array}{l}29.0 \\
29.0\end{array}$ & 1220 & $\begin{array}{l}18 \\
15\end{array}$ & $\begin{array}{l}1.4 \\
1.3\end{array}$ & .030 & 1.0 & .081 & .25 \\
\hline & $\begin{array}{l}2.4 \\
3.0\end{array}$ & $\begin{array}{l}29.0 \\
29.0\end{array}$ & 1120 & $\begin{array}{l}15 \\
15\end{array}$ & $\begin{array}{l}1.3 \\
1.3\end{array}$ & .032 & 1.1 & .070 & .26 \\
\hline
\end{tabular}

8 
Sampling Site 4 near S-5A

\begin{tabular}{|c|c|c|c|c|c|c|c|c|c|}
\hline \multirow[b]{2}{*}{$\begin{array}{l}\text { Time } \\
\text { EDST }\end{array}$} & \multirow[b]{2}{*}{$\begin{array}{l}\text { Depth } \\
\text { metres }\end{array}$} & \multirow[b]{2}{*}{$\begin{array}{c}\text { Temp } \\
\mathrm{C}^{\mathrm{O}}\end{array}$} & \multirow[b]{2}{*}{$\begin{array}{l}\text { Specific } \\
\text { Cond. }\end{array}$} & \multirow{2}{*}{$\begin{array}{l}\text { Percent } \\
\text { satura- } \\
\text { tion DO }\end{array}$} & \multicolumn{5}{|c|}{ mg $/ 1$} \\
\hline & & & & & $\mathrm{DO}$ & $\begin{array}{l}\mathrm{PO}_{4} \\
\text { as P }\end{array}$ & $\begin{array}{l}\mathrm{NH}_{3} \\
\text { as } \mathrm{N}\end{array}$ & $\begin{array}{l}\mathrm{NO}_{2} \\
\text { as } \mathrm{N}\end{array}$ & $\begin{array}{l}\text { No } \\
\text { as: }\end{array}$ \\
\hline \multicolumn{10}{|c|}{ September 10, 1973} \\
\hline \multirow{4}{*}{0822} & 0.3 & 27.0 & 1100 & 20 & 1.7 & .042 & $.4 \mathrm{C}$ & .662 & .31 \\
\hline & 1.2 & 27.0 & & 8 & 0.7 & & & & \\
\hline & 2.4 & 26.5 & 1080 & 2 & -2 & .043 & .56 & .100 & .36 \\
\hline & 3.0 & 26.5 & & 1 & .1 & & & & \\
\hline \multirow{4}{*}{1130} & 0.3 & 29.0 & 1100 & 26 & 2.0 & .041 & .38 & .069 & .29 \\
\hline & 1.2 & 28.5 & & 15 & 1.2 & & & & \\
\hline & 2.4 & 28.0 & 1080 & 3 & .3 & .041 & .40 & .080 & .28 \\
\hline & 3.0 & 28.0 & & l & .1 & & & & \\
\hline \multirow{4}{*}{1505} & 0.3 & 29.0 & 1280 & 21 & $\therefore .7$ & .030 & 1.5 & .084 & .34 \\
\hline & 1.2 & 29.0 & & 17 & 1.4 & & & & \\
\hline & 2.4 & 29.0 & 1360 & 15 & 1.3 & .035 & l. 4 & .086 & .33 \\
\hline & 3.0 & $29 . t$ & & 13 & 1.0 & & & & \\
\hline \multirow{4}{*}{$173 \mathrm{C}$} & 0.3 & 30.0 & 1180 & 28 & 2.2 & .835 & 1.1 & .079 & .33 \\
\hline & 1.2 & 29.5 & & 23 & 1.8 & & & & \\
\hline & 2.4 & 29.0 & 1240 & 33 & $\therefore 1$ & .038 & 1.5 & .081 & .30 \\
\hline & 3.0 & 29.0 & & 13 & $1 . \underline{y}$ & & & & \\
\hline \multirow{4}{*}{2110} & 0.3 & 29.0 & 1240 & 16 & 1.3 & .034 & I. 2 & .075 & .29 \\
\hline & 1.2 & 29.0 & & 15 & 1.2 & & & & \\
\hline & 2.4 & 29.0 & 1220 & 13 & 1.0 & .030 & 1.2 & .084 & .30 \\
\hline & 3.0 & 29.0 & & 9 & .8 & & & & \\
\hline
\end{tabular}


Sampling Site 4 near S-5A (continued)

\begin{tabular}{|c|c|c|c|c|c|c|c|c|c|}
\hline \multirow[b]{2}{*}{$\begin{array}{l}\text { Time } \\
\text { EDST }\end{array}$} & \multirow[b]{2}{*}{$\begin{array}{l}\text { Depth } \\
\text { metres }\end{array}$} & \multirow[b]{2}{*}{$\begin{array}{c}\text { Temp } \\
C^{0}\end{array}$} & \multirow[b]{2}{*}{$\begin{array}{l}\text { Specific } \\
\text { Cond. }\end{array}$} & \multirow{2}{*}{$\begin{array}{l}\text { Percent } \\
\text { satura- } \\
\text { tion DO }\end{array}$} & \multicolumn{5}{|c|}{$\mathrm{mg} / 1$} \\
\hline & & & & & DO & $\begin{array}{l}\mathrm{PO}_{4} \\
\text { as P }\end{array}$ & $\begin{array}{l}\mathrm{NH}_{3} \\
\text { as } \mathrm{N} \\
\end{array}$ & $\begin{array}{l}\mathrm{NO}_{2} \\
\text { as } \mathrm{N} \\
\end{array}$ & $\begin{array}{l}\mathrm{NO}_{3} \\
\text { as } \mathrm{N} \\
\end{array}$ \\
\hline \multicolumn{10}{|c|}{ September 11,1973} \\
\hline \multirow{4}{*}{0700} & 0.3 & 29.0 & $1 \mathbf{I} 00$ & 13 & 1.1 & .046 & .60 & .075 & .27 \\
\hline & 1.2 & 29.0 & & 13 & 1.1 & & & & \\
\hline & 2.4 & 29.0 & 1100 & $\$ 0$ & .9 & .042 & .55 & .072 & .27 \\
\hline & 3.0 & 29.0 & & 10 & .9 & & & & \\
\hline \multirow{4}{*}{1015} & 0.3 & 28.5 & 1080 & 13 & l. l & .040 & .42 & .090 & .25 \\
\hline & 1.2 & 28.0 & & 10 & 0.9 & & & & \\
\hline & 2.4 & 28.0 & 1080 & 9 & .8 & .038 & .42 & .040 & .29 \\
\hline & 3.0 & 28.0 & & 2 & .2 & & & & \\
\hline \multirow{4}{*}{1340} & 0.3 & 30.0 & 1140 & 30 & 2.4 & .043 & .70 & .085 & .28 \\
\hline & $1: 2$ & 29.0 & & 23 & 1.8 & & & & \\
\hline & 2.4 & 29.0 & $11 L 0$ & 13 & 1.0 & .041 & .60 & .080 & .27 \\
\hline & 3.0 & 28.5 & & 7 & .6 & & & & \\
\hline \multirow{4}{*}{1605} & 0.3 & 29.0 & 1180 & 21 & 1.7 & .034 & .98 & .077 & .26 \\
\hline & 1.2 & 29.0 & & 20 & 1.6 & & & & \\
\hline & 2.4 & 29.0 & 1140 & 19 & 1.5 & .025 & 1.0 & .082 & .26 \\
\hline & 3.0 & 28.8 & & 16 & 1.3 & & & & \\
\hline \multirow{4}{*}{2145} & 0.3 & 29.2 & 980 & 24 & 1.9 & .020 & .75 & .052 & .26 \\
\hline & 1.2 & 29.1 & & 20 & 1.6 & & & & \\
\hline & 2.4 & 29.1 & 1100 & 19 & 1.5 & .026 & .95 & .069 & .27 \\
\hline & 3.0 & 29.1 & & 17 & $\therefore 3$ & & & & \\
\hline
\end{tabular}


Sampling Site 4 near S-5A (continued)

\begin{tabular}{|c|c|c|c|c|c|c|c|c|c|}
\hline \multirow[b]{2}{*}{$\begin{array}{l}\text { Time } \\
\text { EDST }\end{array}$} & \multirow[b]{2}{*}{$\begin{array}{l}\text { Depth } \\
\text { metres }\end{array}$} & \multirow[b]{2}{*}{$\begin{array}{c}\text { Temp } \\
\mathrm{C}^{\circ}\end{array}$} & \multirow[b]{2}{*}{$\begin{array}{c}\text { Specific } \\
\text { Cond. }\end{array}$} & \multirow{2}{*}{$\begin{array}{l}\text { Percent } \\
\text { satura- } \\
\text { tion DO }\end{array}$} & \multicolumn{5}{|c|}{$\operatorname{mg} / 1$} \\
\hline & & & & & $\mathrm{DO}$ & $\begin{array}{l}\mathrm{PO}_{4} \\
\text { as } \mathrm{P}\end{array}$ & $\begin{array}{l}\mathrm{NH}_{3} \\
\text { as } \mathrm{N}\end{array}$ & $\begin{array}{l}\mathrm{NO}_{2} \\
\text { as } \mathrm{N}\end{array}$ & $\begin{array}{l}\mathrm{NO}_{3} \\
\mathrm{a} 6 \mathrm{~N}\end{array}$ \\
\hline Septe & 12,197 & & & & & & & & \\
\hline 0655 & & $\begin{array}{l}29.8 \\
29.8\end{array}$ & 1020 & $\begin{array}{l}18 \\
15\end{array}$ & $\begin{array}{l}\vdots .4 \\
\vdots .2\end{array}$ & .045 & .42 & .050 & \\
\hline & & $\begin{array}{l}29.8 \\
29.8\end{array}$ & 1050 & $\begin{array}{l}\vdots 5 \\
14\end{array}$ & $\begin{array}{l}\therefore .2 \\
1.1\end{array}$ & .045 & $.4 \mathrm{C}$ & .069 & .20 \\
\hline
\end{tabular}




\section{Sampling Site 5 near $S-5 A$}

\begin{tabular}{|c|c|c|c|c|c|c|c|c|c|}
\hline \multirow[b]{2}{*}{$\begin{array}{l}\text { Time } \\
\text { EDST } \\
\end{array}$} & \multirow[b]{2}{*}{$\begin{array}{l}\text { Depth } \\
\text { metres }\end{array}$} & \multirow[b]{2}{*}{$\begin{array}{c}\text { Temp } \\
\mathrm{C}^{\mathrm{O}}\end{array}$} & \multirow[b]{2}{*}{$\begin{array}{c}\text { Specific } \\
\text { Cond. }\end{array}$} & \multirow{2}{*}{$\begin{array}{l}\text { Percent } \\
\text { satura- } \\
\text { tion DO }\end{array}$} & \multicolumn{5}{|c|}{$\mathrm{mg} / 1$} \\
\hline & & & & & $\mathrm{DO}$ & $\begin{array}{l}\mathrm{PO}_{4} \\
\text { as } \mathrm{P}\end{array}$ & $\begin{array}{l}\mathrm{NH}_{3} \\
\text { as } \mathrm{N} \\
\end{array}$ & $\begin{array}{l}\mathrm{NO}_{2} \\
\text { as } \mathrm{N}\end{array}$ & $\begin{array}{l}\mathrm{NO}_{3} \\
\text { as N }\end{array}$ \\
\hline \multicolumn{10}{|c|}{ September 10 , 1973} \\
\hline \multirow[t]{2}{*}{0832} & $\begin{array}{l}0.3 \\
1.2\end{array}$ & $\begin{array}{l}27.0 \\
26.5\end{array}$ & 960 & $\begin{array}{r}10 \\
7\end{array}$ & $\begin{array}{r}0.9 \\
.7\end{array}$ & .040 & .40 & .060 & .24 \\
\hline & 2. 4 & 26.0 & 1120 & 4 & .4 & .050 & .40 & .058 & .26 \\
\hline \multirow{4}{*}{$1] 40$} & 0.3 & 29.0 & $\mathrm{l} 020$ & 24 & 1.9 & .043 & .38 & .058 & $.2 \mathrm{l}$ \\
\hline & 1.2 & 29.0 & & 17 & .9 & .043 & .37 & .046 & .23 \\
\hline & 2.4 & 28.0 & $102 \mathrm{C}$ & 4 & .4 & .043 & .36 & .060 & .20 \\
\hline & 3.0 & 28.0 & 1060 & 2 & .2 & .043 & .50 & .100 & .30 \\
\hline \multirow{4}{*}{1520} & 0.3 & 29.0 & 950 & 21 & 2.7 & .050 & .47 & .085 & .32 \\
\hline & L. 2 & 29.0 & 1060 & 16 & 1.3 & .049 & .46 & .082 & .32 \\
\hline & 2.4 & 29.0 & 1060 & 9 & .8 & .046 & .75 & .083 & .32 \\
\hline & 3.0 & 28.5 & $\$ 0 ̈ 60$ & 8 & .7 & .049 & .47 & .080 & .30 \\
\hline \multirow{4}{*}{1740} & 0.3 & 29.0 & 1200 & 20 & 3.7 & .045 & .62 & .075 & .30 \\
\hline & 1.2 & 29.0 & & 17 & 1.4 & & & & \\
\hline & 2.4 & 29.0 & 1100 & 10 & .9 & .046 & .64 & .081 & .30 \\
\hline & 3.0 & 29.0 & & 9 & .8 & & & & \\
\hline \multirow{4}{*}{2120} & 0.3 & 29.0 & 1040 & 19 & 1.5 & .042 & .40 & .067 & .26 \\
\hline & 1.2 & 29.0 & & 17 & 1.4 & & & & \\
\hline & 2.4 & 29.0 & 1040 & 16 & 1.3 & .049 & .42 & .073 & .26 \\
\hline & 3.0 & 29.0 & & 13 & 1.1 & & & & \\
\hline
\end{tabular}


Sampling Site 5 near S-5A (continued)

\begin{tabular}{|c|c|c|c|c|c|c|c|c|c|}
\hline & & & & Percent & & & Ing & & \\
\hline $\begin{array}{l}\text { T'ime } \\
\text { EDST }\end{array}$ & $\begin{array}{l}\text { Depth } \\
\text { metres }\end{array}$ & $\begin{array}{c}\text { Temp } \\
C^{0}\end{array}$ & $\begin{array}{l}\text { Specific } \\
\text { Cond. }\end{array}$ & $\begin{array}{l}\text { satura- } \\
\text { tion DO }\end{array}$ & DO & $\begin{array}{l}\mathrm{FO}_{4} \\
\text { as } \mathrm{P}\end{array}$ & $\begin{array}{l}\mathrm{NH}_{3} \\
\text { as } \mathrm{N}\end{array}$ & $\begin{array}{l}\mathrm{NO} 2 \\
\text { as } \mathrm{N}\end{array}$ & $\begin{array}{l}\mathrm{NO}_{3} \\
\text { as } \mathrm{N}\end{array}$ \\
\hline
\end{tabular}

September 11, 1973

\begin{tabular}{|c|c|c|c|c|c|c|c|c|c|}
\hline & 0.3 & 29.0 & 1020 & 15 & 1.2 & .045 & .38 & .063 & .22 \\
\hline \multirow[t]{4}{*}{0710} & 1.2 & $29 . B$ & 1020 & 14 & 1,1 & .045 & .38 & .063 & .22 \\
\hline & 2.4 & 29.0 & 1030 & 14 & 1.1 & .041 & .37 & .062 & .21 \\
\hline & 3.0 & 29.0 & & 12 & 1.0 & & & & \\
\hline & 0.3 & 28.5 & 1020 & 17 & 1.4 & .040 & .30 & .031 & .23 \\
\hline \multirow[t]{4}{*}{1025} & $1.2:$ & 28.5 & 1040 & 14 & E. 1 & .040 & .30 & .031 & .23 \\
\hline & 2.4 & 28,0 & 1050 & 12 & 1.0 & .042 & .30 & .030 & .23 \\
\hline & 3.0 & 28.0 & 1040 & 10 & .9 & .042 & .35 & .026 & .22 \\
\hline & 0.3 & 29.5 & 1040 & 32 & 2.5 & .042 & -40 & .060 & .21 \\
\hline \multirow[t]{4}{*}{1400} & 1.2 & 29.5 & & 17 & 1.4 & & & & \\
\hline & 2.4 & 28.5 & 1040 & 12 & 1.0 & .040 & .40 & .058 & .21 \\
\hline & 3.0 & 28.5 & & 7 & .6 & & & & \\
\hline & 0.3 & 30.0 & & 32 & 2.4 & .035 & .70 & .063 & .26 \\
\hline \multirow[t]{4}{*}{1625} & 1.2 & 29.8 & & 27 & 2,1 & & & & \\
\hline & 2.4 & 29.5 & 1010 & 21 & I. 7 & .038 & .75 & .070 & .26 \\
\hline & 3.0 & 29.5 & & 21 & $i .7$ & & & & \\
\hline & 0.3 & 29.2 & 1040 & 16 & 1.3 & .036 & $.4 \mathrm{G}$ & .056 & .23 \\
\hline \multirow[t]{3}{*}{2200} & 1.2 & 29.2 & & 16 & 1.3 & & & & \\
\hline & 2.4 & 29.2 & 1040 & 16 & 1.3 & .036 & .40 & .050 & .22 \\
\hline & 3.0 & 29.0 & & 15 & 1.2 & & & & \\
\hline
\end{tabular}


Sampling Site 5 near S-5A (continued)

\begin{tabular}{|c|c|c|c|c|c|c|c|c|c|}
\hline & & & & Percent & \multicolumn{5}{|c|}{$\mathrm{mg} / \mathrm{l}$} \\
\hline $\begin{array}{l}\text { Time } \\
\text { EDST }\end{array}$ & $\begin{array}{l}\text { Depth } \\
\text { metres }\end{array}$ & $\begin{array}{c}\text { Temp } \\
\mathrm{C}^{\mathrm{O}}\end{array}$ & $\begin{array}{l}\text { Spesific } \\
\text { Cond. }\end{array}$ & $\begin{array}{l}\text { satura- } \\
\text { tion DO }\end{array}$ & $\mathrm{DO}$ & $\begin{array}{l}\mathrm{PO}_{4} \\
\text { as } \mathrm{P}\end{array}$ & $\begin{array}{l}\mathrm{NH}_{3} \\
\text { as } \mathrm{N}\end{array}$ & $\begin{array}{l}\mathrm{NO} 2 \\
\text { as } \mathrm{N}\end{array}$ & $\begin{array}{l}\mathrm{NO}_{3} \\
\text { as } \mathrm{N}\end{array}$ \\
\hline
\end{tabular}

September I2, $\$ 973$

$\begin{array}{clllllllll}0710 & 0.3 & 29.5 & 1020 & 16 & 1.3 & .050 & .43 & .031 & .16 \\ & 1.2 & 29.5 & 1020 & 16 & 1.3 & .046 & .40 & .034 & .17 \\ & 2.4 & 29.5 & 1020 & 16 & 1.3 & .049 & .40 & .040 & .16 \\ & 3.0 & 29.5 & 1005 & 16 & 1.3 & .053 & .44 & .019\end{array}$


Sampling Site 6 near S-5A

\begin{tabular}{|c|c|c|c|c|c|c|c|c|c|}
\hline \multirow[b]{2}{*}{$\begin{array}{l}\text { Time } \\
\text { EDST }\end{array}$} & \multirow[b]{2}{*}{$\begin{array}{l}\text { Depth } \\
\text { metres }\end{array}$} & \multirow[b]{2}{*}{$\begin{array}{c}\text { Temp } \\
\mathrm{C}^{\circ}\end{array}$} & \multirow[b]{2}{*}{$\begin{array}{l}\text { Specisic } \\
\text { Cond. }\end{array}$} & \multirow{2}{*}{$\begin{array}{l}\text { Percent } \\
\text { satura- } \\
\text { tion Do }\end{array}$} & \multicolumn{5}{|c|}{$\mathrm{mg} / 1$} \\
\hline & & & & & DO & $\begin{array}{l}\mathrm{PO}_{4} \\
\text { as P }\end{array}$ & $\begin{array}{l}\mathrm{NH}_{3} \\
\text { as } \mathrm{N}\end{array}$ & $\begin{array}{l}\mathrm{NO}_{2} \\
\text { as } \mathrm{N}\end{array}$ & $\begin{array}{l}\mathrm{NO}_{3} \\
\text { as } \mathrm{N}\end{array}$ \\
\hline
\end{tabular}

September 10, 1973

$\begin{array}{lrrrrrrrrrr}0840 & 0.3 & 26.0 & 780 & 5 & 0.5 & .032 & .30 & .000 & .015 \\ 1155 & .3 & 29.0 & 850 & 28 & 2.2 & .025 & .32 & .012 & .00 \\ 1530 & .3 & 30.5 & & 29 & 2.2 & .040 & .35 & .055 & .22 \\ 1750 & .3 & 29.0 & 955 & 7 & 0.6 & .025 & .31 & .013 & .01 \\ 2125 & & 28.8 & 780 & 7 & 0.6 & .025 & .30 & .013 & .03\end{array}$

5 September 11, 1973

$\begin{array}{llllllllll}0725 & .3 & 28.0 & 900 & 7 & 0.6 & .030 & .30 & .030 & .08 \\ 1030 & .3 & 27.0 & 740 & 5 & 0.5 & .012 & .18 & .005 & .00 \\ 1410 & .3 & 31.0 & 970 & 29 & 2.2 & & .04 & .032 \\ 1630 & .3 & 29.3 & 970 & 20 & 1.6 & .030 & .03 & .18 . \\ 2205 & .3 & 28.7 & 895 & 17 & 1.4 & .015 & .30 & .013 & .09\end{array}$

September 12, 1973

0715

.3

29.6

995

0.7

.040

.41

$.03{ }^{\prime}$

.13 
Sampling Site 3 near $8-5 \mathrm{~A}$

\begin{tabular}{|c|c|c|c|c|c|c|c|c|c|}
\hline \multirow[b]{2}{*}{$\begin{array}{l}\text { Time } \\
\text { EDST } \\
\end{array}$} & \multirow[b]{2}{*}{$\begin{array}{l}\text { Depth } \\
\text { metros }\end{array}$} & \multirow[b]{2}{*}{$\begin{array}{c}\text { Temp } \\
\mathrm{C}^{\circ}\end{array}$} & \multirow[b]{2}{*}{$\begin{array}{l}\text { Specisic } \\
\text { Cond. }\end{array}$} & \multirow{2}{*}{$\begin{array}{l}\text { Percent } \\
\text { satura- } \\
\text { tion DO }\end{array}$} & \multicolumn{5}{|c|}{$\operatorname{mg} / 1$} \\
\hline & & & & & DO & $\begin{array}{l}\mathrm{PO}_{4} \\
\text { as } \mathrm{P}\end{array}$ & $\begin{array}{l}\mathrm{NH}_{3} \\
\text { as } \mathrm{N} \\
\end{array}$ & $\begin{array}{l}\mathrm{NO}_{2} \\
\text { as } \mathrm{N}\end{array}$ & $\begin{array}{l}\mathrm{NO}_{3} \\
\text { as } \mathrm{N} \\
\end{array}$ \\
\hline \multicolumn{10}{|c|}{ September $\geq 5,1973$} \\
\hline \multirow{3}{*}{3540} & 0.3 & $\begin{array}{l}29.5 \\
290\end{array}$ & iC4G & 19 & 3.5 & .045 & .43 & .067 & .21 \\
\hline & $\begin{array}{l}1.2 \\
2.44\end{array}$ & $\begin{array}{l}29.0 \\
29.0\end{array}$ & & -5 & ?.2 & & & & \\
\hline & 3.0 & 23.5 & & 7 & 6.6 & .045 & $.4 !$ & .067 & $.2 \mathrm{l}$ \\
\hline \multirow{4}{*}{1 लि: } & 0.3 & 29.5 & $3: 00$ & 19 & .5 & +.944 & .39 & .055 & .22 \\
\hline & 1.2 & 29.5 & & $: 9$ & .5 & & & & \\
\hline & 2.4 & 29.0 & 1020 & 5 & $\therefore 2$ & .045 & $.4:$ & .060 & .20 \\
\hline & 3.0 & 29.0 & & $\because$ & .9 & & & & \\
\hline \multirow{3}{*}{2135} & 0.3 & 29.0 & 1000 & 19 & 1.5 & .045 & .38 & .055 & +18 \\
\hline & $1-2$ & 29.6 & & 16 & $\therefore 3$ & & & & \\
\hline & $\begin{array}{l}2.4 \\
3.0\end{array}$ & $\begin{array}{l}39 .: \\
29.0\end{array}$ & - co5 & $\therefore 6$ & 1.3 & .042 & .35 & .050 & .20 \\
\hline
\end{tabular}

september: 1,1973

\begin{tabular}{|c|c|c|c|c|c|c|c|c|c|}
\hline \multirow{4}{*}{0730} & 0.3 & 20,8 & .150 & 12 & $\overline{1} .0$ & .052 & .40 & .050 & .13 \\
\hline & 1.2 & 28.0 & & 9 & .9 & & & & \\
\hline & 2.4 & 20.0 & $=000$ & 9 & .8 & .055 & .38 & .047 & .14 \\
\hline & 3.0 & $2 \because 0$ & & $\bar{i}$ & .5 & & & & \\
\hline \multirow{2}{*}{-040} & $\begin{array}{l}0.3 \\
1.2\end{array}$ & $\begin{array}{l}28 . \vdots \\
28\end{array}$ & $: 420$ & $\because 3$ & $\therefore 3$ & .043 & .30 & .025 & .15 \\
\hline & $\begin{array}{l}2.4 \\
3.0\end{array}$ & $\begin{array}{l}25.0 \\
28.0\end{array}$ & 1340 & $\begin{array}{l}2 \\
7\end{array}$ & .7 & .043 & .30 & .025 & .16 \\
\hline
\end{tabular}




\begin{tabular}{|c|c|c|c|c|c|c|c|c|c|}
\hline \multirow[b]{2}{*}{$\begin{array}{l}\text { Time } \\
\text { EDST }\end{array}$} & \multirow[b]{2}{*}{$\begin{array}{l}\text { Depth } \\
\text { metres }\end{array}$} & \multirow[b]{2}{*}{$\begin{array}{c}\text { Temp } \\
C^{0}\end{array}$} & \multirow[b]{2}{*}{$\begin{array}{l}\text { Specizic } \\
\text { Cond. }\end{array}$} & \multirow{2}{*}{$\begin{array}{l}\text { Percent } \\
\text { satura- } \\
\text { tion DO }\end{array}$} & \multirow[b]{2}{*}{ DO } & \multicolumn{4}{|c|}{$\mathrm{mg} / 1$} \\
\hline & & & & & & $\begin{array}{l}\mathrm{PO}_{4} \\
\text { as P }\end{array}$ & $\begin{array}{l}\mathrm{NH}_{3} \\
\text { as } \mathrm{N}\end{array}$ & $\begin{array}{l}\mathrm{NO}_{2} \\
\text { as } \mathrm{N}\end{array}$ & $\begin{array}{l}\mathrm{NO} \\
\text { as }\end{array}$ \\
\hline \multicolumn{10}{|c|}{ Seplemier il, :973 (continued) } \\
\hline \multirow{4}{*}{1413} & 0.3 & $29.1:$ & $\because \because 40$ & 26 & 2. & .045 & .40 & .040 & .16 \\
\hline & 1. .2 & 29.4 & & 16 & $\therefore .4$ & & & & \\
\hline & $2 . \div$ & 2.5 & $80 \%$ & 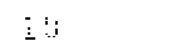 & .9 & .049 & .40 & .040 & .15 \\
\hline & 3.0 & 29.4 & & 5 & .5 & & & & \\
\hline \multirow{4}{*}{60} & 0.3 & 2.9 .5 & 920 & 25 & 2.0 & .040 & .40 & .050 & .18 \\
\hline & 1.2 & 29.4 & & 25 & 2.6 & & & & \\
\hline & 2.4 & 2.9 .2 & : Ou: & 20 & .7 & .046 & .42 & .051 & .23 \\
\hline & 3.0 & 29.2 & & $2 \mathrm{C}$ & 1.7 & & & & \\
\hline \multirow{4}{*}{$220 \overrightarrow{3}$} & 0.3 & 29.1 & -820 & 20 & $=6$ & .050 & .96 & .038 & .16 \\
\hline & 1.2 & 29. & & 19 & $\therefore 5$ & & & & \\
\hline & 2.4 & 29.0 & 1000 & 19 & $\Xi 5$ & .045 & .38 & .025 & .18 \\
\hline & 3.0 & 29.0 & & $: 9$ & 1.5 & & & & \\
\hline
\end{tabular}

Septinnber 12,1973

\begin{tabular}{|c|c|c|c|c|c|c|c|c|c|}
\hline \multirow{4}{*}{0225} & 0.3 & 29.2 & \multirow[t]{2}{*}{990} & -5 & 1.2 & \multirow[t]{2}{*}{.038} & \multirow[t]{2}{*}{.40} & \multirow[t]{2}{*}{.025} & \multirow[t]{2}{*}{.10} \\
\hline & 1.2 & 29.2 & & .5 & 1.2 & & & & \\
\hline & 2.4 & 29.5 & 990 & 15 & 1.2 & .050 & .37 & .012 & .11 \\
\hline & 3.0 & 29.2 & & $? .5$ & 1.2 & & & & \\
\hline
\end{tabular}


Sampling Site, west Canal, L-28

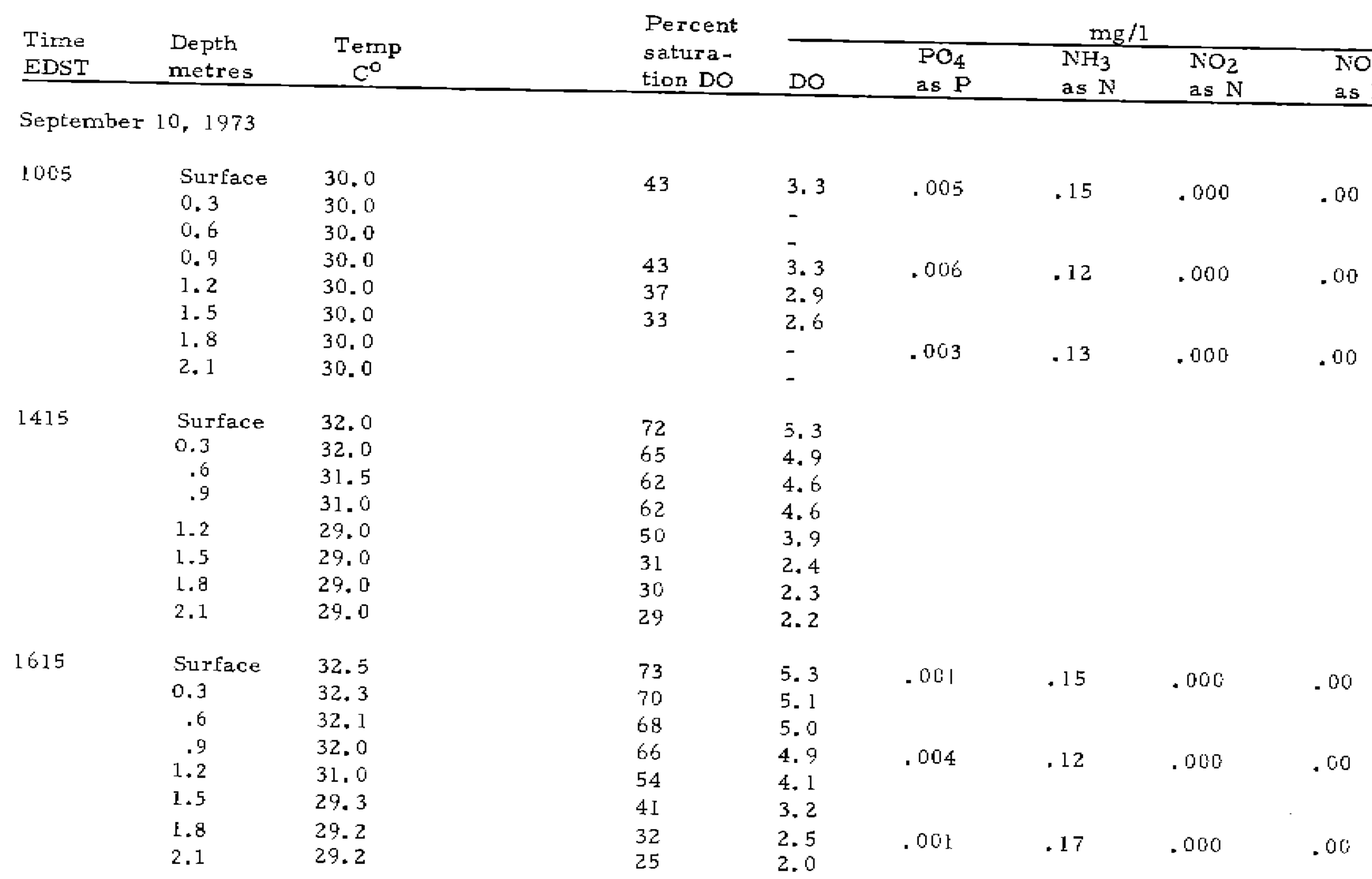


Sampling Site, West Canal, L-28 (continued)

\begin{tabular}{|c|c|c|c|c|}
\hline $\begin{array}{l}\text { Time } \\
\text { EDST }\end{array}$ & $\begin{array}{l}\text { Dept' } \\
\text { metres }\end{array}$ & $\begin{array}{c}\text { Temp } \\
\mathrm{C}^{\mathrm{O}} \\
\end{array}$ & $\begin{array}{l}\text { Percent } \\
\text { satura- } \\
\text { tion Do }\end{array}$ & DO \\
\hline \multirow[t]{8}{*}{1905} & SurEace & 32.2 & 60 & 4.4 \\
\hline & 0.3 & 32.2 & 59 & 4.3 \\
\hline & .6 & 32.2 & 59 & 4.3 \\
\hline & .9 & 32.1 & 60 & 4.4 \\
\hline & 1.2 & 32.0 & 60 & 4.4 \\
\hline & 1.5 & 32.0 & 56 & 4.1 \\
\hline & 1.8 & 29.8 & 32 & 2.5 \\
\hline & 2.1 & 29.0 & $2]$ & 1.7 \\
\hline \multirow[t]{8}{*}{2200} & Sirface & 31.0 & 42 & 3.2 \\
\hline & $\mathrm{C} .3$ & 31.0 & 42 & 3.2 \\
\hline & 0.6 & 31.0 & 42 & 3.2 \\
\hline & .9 & 30.9 & 42 & 3.2 \\
\hline & 1.2 & 36.5 & 41 & 3.1 \\
\hline & 1.5 & 30.0 & 40 & 3.1 \\
\hline & 1.8 & 29.2 & 24 & 1.9 \\
\hline & 2.1 & 28.5 & 13 & 1.0 \\
\hline
\end{tabular}

September 11,1973

\begin{tabular}{|c|c|c|}
\hline 0100 & Suriace & 30.3 \\
\hline & 0.3 & 30.3 \\
\hline & .6 & 30.1 \\
\hline & .9 & 30. \\
\hline & L. 2 & 30.0 \\
\hline & $\begin{array}{l}1.5 \\
1.8\end{array}$ & $\begin{array}{l}29.8 \\
29.0\end{array}$ \\
\hline & $2 . I$ & 28.5 \\
\hline
\end{tabular}

$\begin{array}{rr}36 & 2.8 \\ 36 & 2.8 \\ 36 & 2.8 \\ 36 & 2.8 \\ 35 & 2.7 \\ 33 & 2.6 \\ 20 & 1.6 \\ 8 & 0.7\end{array}$


Sampling Site, West Cana1, L-28 (continued)

\begin{tabular}{|c|c|c|c|c|c|c|c|c|}
\hline \multirow[b]{2}{*}{$\begin{array}{l}\text { Time } \\
\text { EDST } \\
\end{array}$} & \multirow[b]{2}{*}{$\begin{array}{l}\text { Depth } \\
\text { metres }\end{array}$} & \multirow[b]{2}{*}{$\begin{array}{c}\text { Temp } \\
\mathrm{C}^{\circ}\end{array}$} & \multirow{2}{*}{$\begin{array}{l}\text { Percent } \\
\text { satira- } \\
\text { tion DO } \\
\end{array}$} & \multicolumn{5}{|c|}{$\mathrm{mg} / \mathrm{l}$} \\
\hline & & & & DO & $\begin{array}{l}\mathrm{PO}_{4} \\
\text { as } \mathrm{P}\end{array}$ & $\begin{array}{l}\mathrm{NH}_{3} \\
\text { as } \mathrm{N} \\
\end{array}$ & $\begin{array}{l}\mathrm{NO}_{2} \\
\text { as } \mathrm{N} \\
\end{array}$ & $\begin{array}{l}\mathrm{NO}_{3} \\
\text { as } \mathrm{N} \\
\end{array}$ \\
\hline \multirow[t]{8}{*}{0430} & Surface & 29.8 & 34 & 2.7 & & & & \\
\hline & 0.3 & 29.8 & 34 & 2.7 & & & & \\
\hline & .6 & 29.7 & 33 & 2.6 & & & & \\
\hline & .9 & 29.5 & 33 & 2.6 & & & & \\
\hline & 1.2 & 29.5 & 33 & 2.6 & & & & \\
\hline & I. 5 & 29.5 & 33 & 2.6 & & & & \\
\hline & 1.8 & 29.0 & 32 & 2.5 & & & & \\
\hline & 2.1 & 29.0 & 14 & 1.6 & & & & \\
\hline \multirow[t]{8}{*}{0700} & Surface & 29.1 & 29 & 2.3 & .002 & .21 & .000 & 01 \\
\hline & 0.3 & 29.1 & 29 & 2.3 & & & & \\
\hline & .6 & 29.1 & 29 & 2.3 & & & & \\
\hline & .9 & 29.1 & 27 & 2.2 & .003 & .17 & .000 & .00 \\
\hline & 1.2 & 29.0 & 27 & 2.2 & & & & \\
\hline & 1.5 & 29.0 & 27 & 2.3 & & & & \\
\hline & 1.8 & 29.0 & 27 & 2.3 & .002 & .20 & .000 & .00 \\
\hline & 2.1 & 29.0 & 25 & 2.0 & & & & \\
\hline
\end{tabular}


Sampling Site, East Canal, L-28

\begin{tabular}{|c|c|c|c|c|c|c|c|c|}
\hline \multirow[b]{2}{*}{$\begin{array}{l}\text { Time } \\
\text { EDSI } \\
\end{array}$} & \multirow[b]{2}{*}{$\begin{array}{l}\text { Depth } \\
\text { metres }\end{array}$} & \multirow[b]{2}{*}{$\begin{array}{c}\text { Temp } \\
\mathrm{C}^{\mathrm{o}} \\
\end{array}$} & \multirow{2}{*}{$\begin{array}{l}\text { Percent } \\
\text { satura- } \\
\text { tioil DO }\end{array}$} & \multicolumn{5}{|c|}{$\mathrm{mg} / 1$} \\
\hline & & & & DO & $\begin{array}{l}\mathrm{PO}_{4} \\
\text { as } \mathrm{P}\end{array}$ & $\begin{array}{l}\mathrm{NH}_{3} \\
\text { as } \mathrm{N}\end{array}$ & $\begin{array}{l}\mathrm{NO}_{2} \\
\mathrm{as} \mathrm{N}\end{array}$ & $\begin{array}{l}\mathrm{NO}_{3} \\
\text { as N }\end{array}$ \\
\hline \multicolumn{9}{|c|}{ September 10, 1973} \\
\hline \multirow[t]{8}{*}{1015} & Surface & 31,0 & 53 & 4.0 & .005 & .12 & .000 & .00 \\
\hline & 0.3 & 30.5 & 46 & 3.5 & & & & \\
\hline & .6 & 30.5 & 42 & 3.2 & & & & \\
\hline & .9 & 30,0 & $4 \mathrm{C}$ & 3.1 & .003 & .11 & .000 & .00 \\
\hline & 1.2 & 30,0 & 42 & 3.3 & & & & \\
\hline & 1.5 & 30,0 & 44 & 3.4 & & & & \\
\hline & 1.8 & 30.0 & 44 & 3.4 & .005 & .16 & .000 & .00 \\
\hline & 2.1 & 30.0 & 44 & 3.4 & & & & \\
\hline \multirow[t]{8}{*}{1400} & Surface & 32.0 & 62 & 4.6 & & & & \\
\hline & 0.3 & 32.0 & 55 & 4.1 & & & & \\
\hline & .6 & 32.0 & 48 & 3.5 & & & & \\
\hline & .9 & 31.5 & 45 & 3.4 & & & & \\
\hline & 1.2 & 31.0 & 54 & 4.2 & & & & \\
\hline & 1.5 & 30.5 & 53 & 4.0 & & & & \\
\hline & 1.8 & $3 \mathrm{C} .2$ & 34 & 2.7 & & & & \\
\hline & 2.1 & - & - & 3.6 & & & & \\
\hline \multirow[t]{8}{*}{1600} & Surface & 31.0 & 75 & 5.7 & .005 & .12 & .000 & .00 \\
\hline & 0.3 & 31,0 & 45 & 3.4 & & & & \\
\hline & .6 & 31.0 & 45 & 3.4 & & & & \\
\hline & .9 & 30.5 & 44 & 3.4 & .002 & .15 & .000 & .00 \\
\hline & 1.2 & 30.0 & 45 & 3.5 & & & & \\
\hline & 1.5 & 30.0 & 51 & 3.9 & & & & \\
\hline & 1.8 & 35.0 & 53 & 4,1 & .003 & .10 & .000 & .00 \\
\hline & 2.1 & 30.0 & 43 & 3.3 & & & & \\
\hline
\end{tabular}


Sampling Site, East Canal, L-28 icontinued)

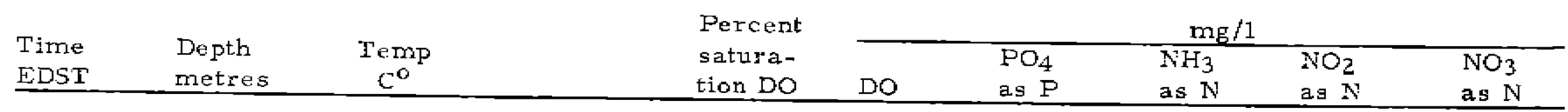

September 10, 1973 (continued)

$\begin{array}{lllll}\text { igoc } & \text { Surface } & 30.4 & 52 & 4.0 \\ 0.3 & 30.4 & 48 & 3.7 \\ 0.6 & 30.4 & 47 & 3.6 \\ .9 & 30.2 & 43 & 3.3 \\ 1.2 & 30.2 & 42 & 3.2 \\ 1.5 & 30.0 & 39 & 3.0 \\ 1.8 & 30.0 & 44 & 3.4 \\ 2.1 & 30.0 & 42 & 3.2 \\ 2200 & & & \\ & \text { Surface } & 30.5 & 53 & 4.1 \\ & .3 & 36.5 & 50 & 3.8 \\ & .6 & 30.3 & 50 & 3.8 \\ & .9 & 30.3 & 50 & 3.9 \\ 1.2 & 30.1 & 51 & 4.0 \\ 1.5 & 36.1 & 51 & 4.0 \\ 1.8 & 30.0 & 43 & 3.3 \\ 2.1 & 30.0 & 31 & 2.4\end{array}$

September 11, 1973

0160

$\begin{array}{ll}\text { Surface } & 30.2 \\ 0.3 & 30.2 \\ .6 & 30.1 \\ .9 & 30.0 \\ 1.2 & 30.0 \\ 1.5 & 30.0 \\ 1.8 & 30.0 \\ 2.1 & 29.8\end{array}$

4.0

3. 3

3.2

3.0

3. 2

4. 1

3. 8

3. 8

4.0

4.0

2. 4

$\begin{array}{ll}44 & 3.4 \\ 44 & 3.4 \\ 42 & 3.3 \\ 42 & 3.2 \\ 42 & 3.2 \\ 36 & 2.8 \\ 33 & 2.6 \\ 30 & 2.4\end{array}$


Sampling Site, East Canal, L-28 (continued)

\begin{tabular}{|c|c|c|c|c|c|c|c|c|}
\hline \multirow[b]{2}{*}{$\begin{array}{l}\text { Time } \\
\text { EDST }\end{array}$} & \multirow[b]{2}{*}{$\begin{array}{l}\text { Depth } \\
\text { metres }\end{array}$} & \multirow[b]{2}{*}{$\begin{array}{c}\text { Temp } \\
\mathrm{C}^{\mathrm{O}}\end{array}$} & \multirow{2}{*}{$\begin{array}{l}\text { Percent } \\
\text { satura- } \\
\text { tion DO }\end{array}$} & \multicolumn{5}{|c|}{$\mathrm{mg} / 1$} \\
\hline & & & & DO & $\begin{array}{l}\overrightarrow{\mathrm{PO}_{4}} \\
\text { as } \mathrm{P}\end{array}$ & $\begin{array}{l}\mathrm{NH}_{3} \\
\text { as } \mathrm{N}\end{array}$ & $\begin{array}{l}\mathrm{NO}_{2} \\
\mathrm{as} \mathrm{N}\end{array}$ & $\begin{array}{l}\mathrm{NO}_{3} \\
\text { as } \mathrm{N}\end{array}$ \\
\hline
\end{tabular}

September 11, 1973 (continued)

\begin{tabular}{|c|c|c|c|c|c|c|c|c|}
\hline \multirow[t]{8}{*}{0415} & Surface & 30.4 & 38 & 3.0 & & & & \\
\hline & 0.3 & 30.4 & 38 & 3.0 & & & & \\
\hline & .6 & 30.4 & 38 & 3.0 & & & & \\
\hline & .9 & 30.2 & 38 & 3.0 & & & & \\
\hline & 1.2 & 30.2 & 38 & 3.0 & & & & \\
\hline & 1.5 & 30.0 & 34 & 2.7 & & & & \\
\hline & 1.8 & 30.0 & 34 & 2.7 & & & & \\
\hline & 2.1 & 29.0 & 26 & 2.1 & & & & \\
\hline \multirow[t]{8}{*}{0715} & Surface & 30.0 & 35 & 2.7 & .002 & .17 & .000 & .00 \\
\hline & 0.3 & 30.0 & 36 & 2.8 & & & & \\
\hline & .6 & 30.0 & 36 & 2.8 & & & & \\
\hline & .9 & 30.0 & 33 & 2.6 & .006 & .12 & .000 & .00 \\
\hline & 1.2 & 30.0 & 33 & 2.6 & & & & \\
\hline & 1.5 & 29.9 & 33 & 2.6 & & & & \\
\hline & 1.8 & 29.8 & 30 & 2.4 & .006 & .12 & .000 & .80 \\
\hline & 2. 1 & 29.8 & 27 & 2.1 & & & & \\
\hline
\end{tabular}


BASIC DATA F

Vegetative quadrats in Conservation Area 1, November. 13-14, 1973. 


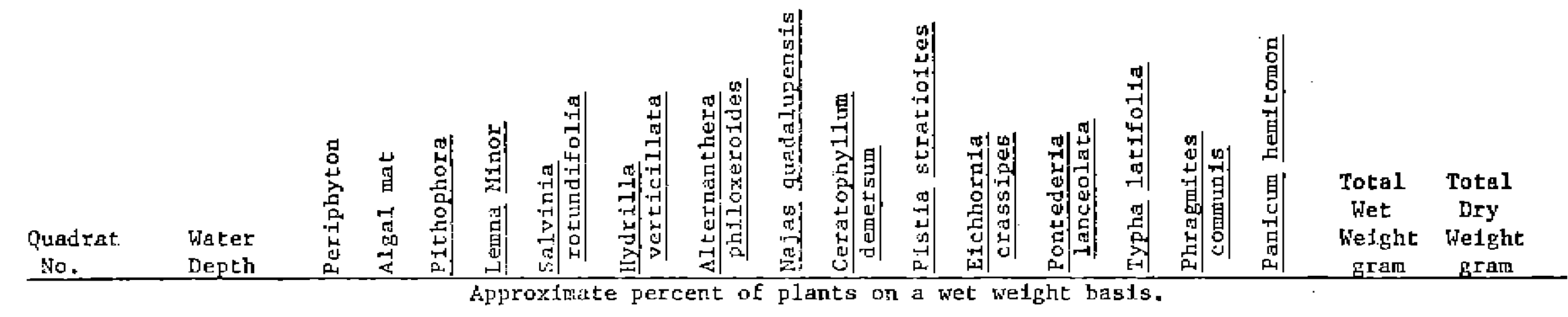

\begin{tabular}{|c|c|c|c|c|c|c|c|c|c|c|c|c|c|c|c|c|c|c|}
\hline 1 & $0.76 \mathrm{ar}$ & - & - & 10 & 41 & - & 22 & 5 & 2 & 10 & - & - & - & - & 50 & - & 6971 & 572 \\
\hline$\stackrel{\Xi}{\Xi}^{2}$ & .76 & - & 4 & 10 & $<1$ & - & 75 & 1 & 2 & 4 & - & - & - & - & 7 & - & 7771 & 587 \\
\hline 3 & .82 & - & 41 & - & - & - & 33 & 1 & 33 & 33 & - & - & - & - & - & - & 495 & 37 \\
\hline 4 & .79 & - & 10 & - & 5 & - & 36 & - & 36 & 5 & - & - & - & - & 2 & - & 5200 & 367 \\
\hline 5 & .64 & - & $\cdot 1$ & - & - & - & 5 & 80 & 15 & - & - & - & - & - & - & - & 3657 & 318 \\
\hline 6 & .61 & - & - & - & 2 & - & 1 & 20 & 1 & 1 & 2 & - & - & 67 & - & - & 12890 & 1110 \\
\hline 7 & .62 & - & - & - & 1 & - & - & 16 & - & 1 & - & - & - & 82 & - & - & 14660 & 1470 \\
\hline 8 & .59 & - & - & - & - & - & - & 5 & - & - & - & - & 90 & - & 5 & - & 23600 & \\
\hline
\end{tabular}


Vegetative Quadrat Data for Conservetion Area 1, 13-14 Nov. 1973

Site 2 - Two and one-half miles southeast of Pump Station S-5A,

Marsh adjacent to and west of Levee 40 Canal.

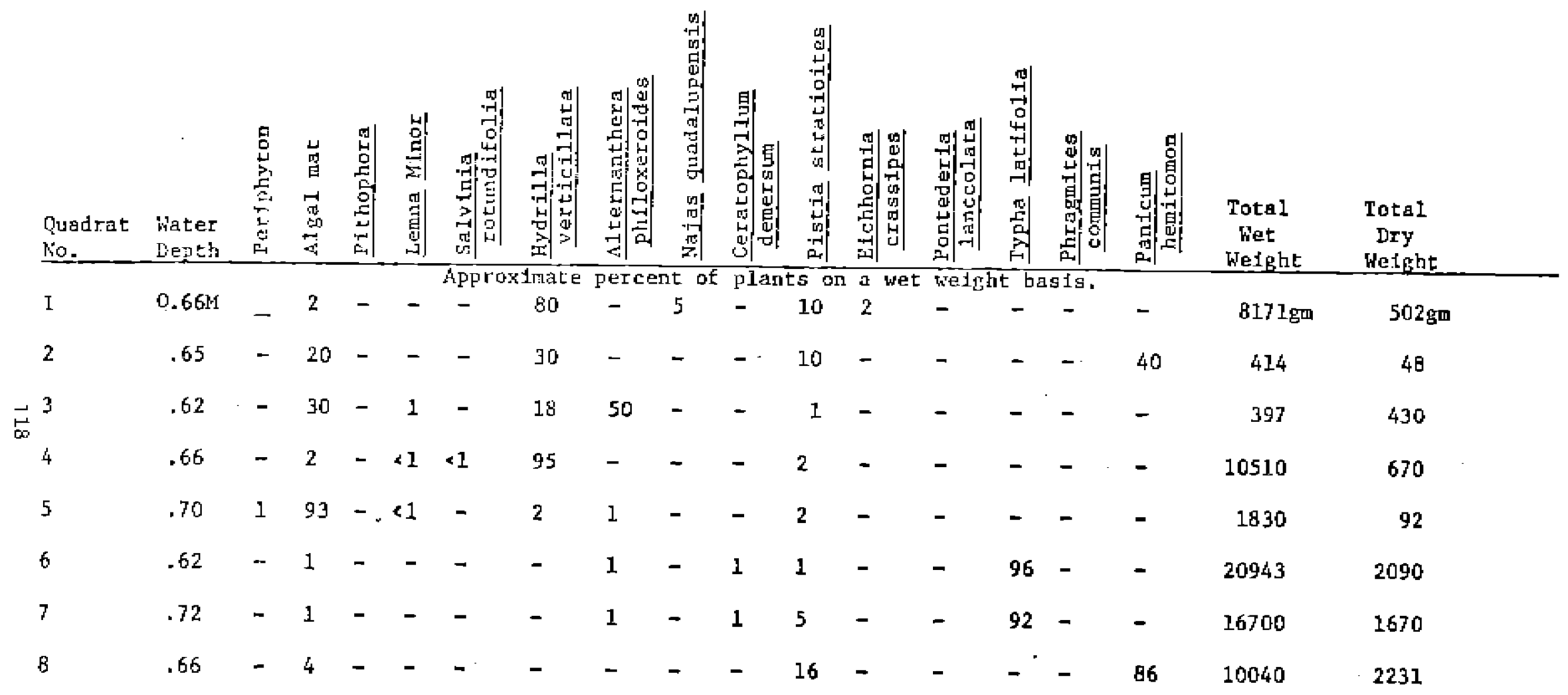




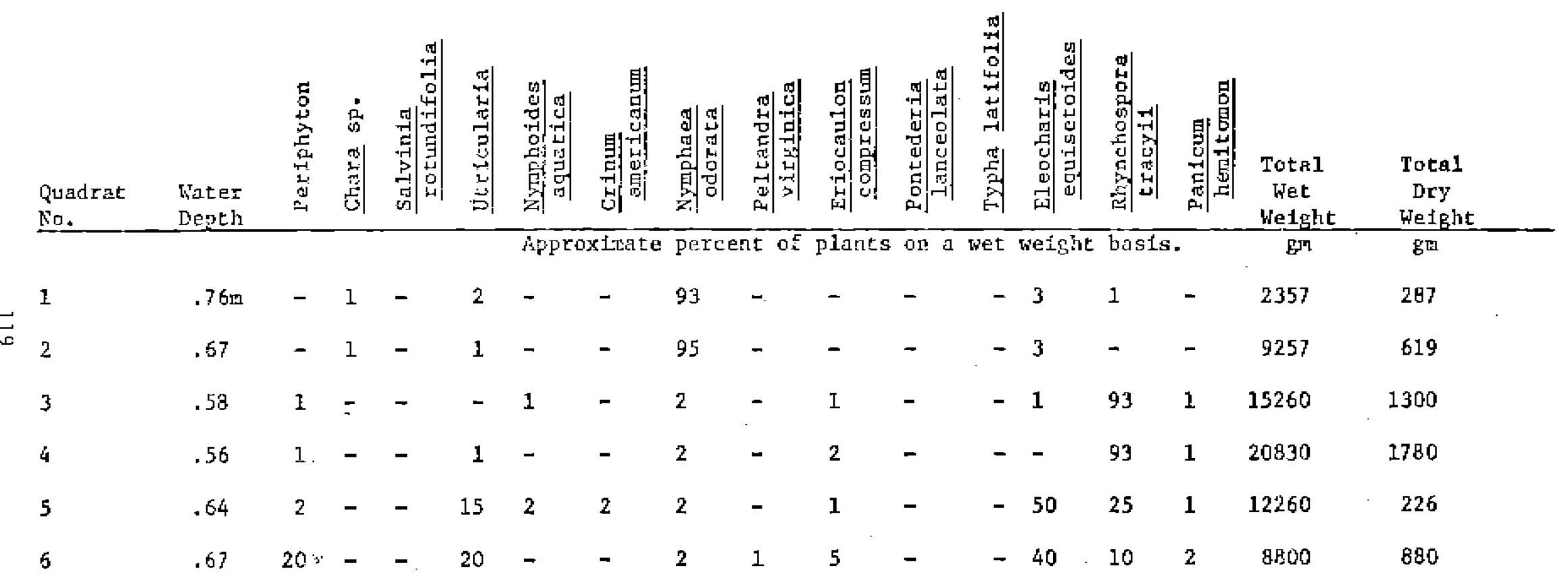


Vegetat1ve Quadrat Data for Coneervation Area 1, 13-14 Wov, 1973

Site 4 - Near Edgar's Island. Approkimately 5 miles sputhwest

of Loxahatchee National Wildife Refuge Headquarters.

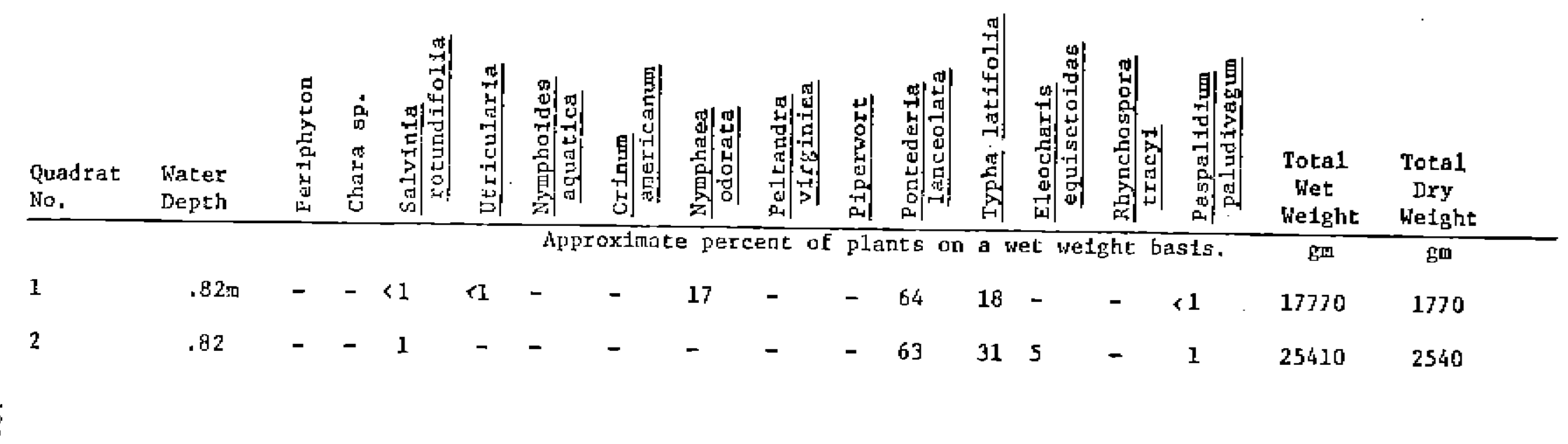

